\title{
Vietnam: 2004 Article IV Consultation-Staff Report; Public Information Notice on the Executive Board Discussion; and Statement by the Executive Director for Vietnam
}

Under Article IV of the IMF's Articles of Agreement, the IMF holds bilateral discussions with members, usually every year. In the context of the 2004 Article IV consultation with Vietnam, the following documents have been released and are included in this package:

- $\quad$ the staff report for the 2004 Article IV consultation, prepared by a staff team of the IMF, following discussions that ended on September 9, 2004, with the officials of Vietnam on economic developments and policies. Based on information available at the time of these discussions, the staff report was completed on November 5, 2004. The views expressed in the staff report are those of the staff team and do not necessarily reflect the views of the Executive Board of the IMF.

- $\quad$ a Public Information Notice (PIN) summarizing the views of the Executive Board as expressed during its November 22, 2004 discussion of the staff report that concluded the Article IV consultation.

- $\quad$ a statement by the Executive Director for Vietnam.

The policy of publication of staff reports and other documents allows for the deletion of market-sensitive information.

To assist the IMF in evaluating the publication policy, reader comments are invited and may be sent by e-mail to publicationpolicy@imf.org.

$$
\begin{gathered}
\text { Copies of this report are available to the public from } \\
\text { International Monetary Fund • Publication Services } \\
70019^{\text {th }} \text { Street, N.W. • Washington, D.C. 20431 } \\
\text { Telephone: (202) 623-7430 • Telefax: (202) 623-7201 } \\
\text { E-mail: publications@imf.org • Internet: http://www.imf.org }
\end{gathered}
$$

Price: $\$ 15.00$ a copy

\section{International Monetary Fund Washington, D.C.}





\title{
INTERNATIONAL MONETARY FUND
}

\author{
VIETNAM
}

\section{Staff Report for the 2004 Article IV Consultation}

Prepared by the Staff Representatives for the 2004 Consultation with Vietnam

Approved by Masahiko Takeda and Anthony Boote

November 5, 2004

- $\quad$ A mission visited Hanoi and Ho Chi Minh City during August 25-September 9 to conduct the 2004 Article IV consultation and discuss the Ex Post Assessment (EPA) of Vietnam's long-term program engagement with the Fund.

- $\quad$ The team comprised Mr. Ishii (head), Mr. Aitken, and Ms. Al-Mashat (all APD), Ms. Muñoz (formerly APD, currently AFR), Mr. Wang (formerly PDR, currently APD), and Mr. Lueth (FAD), and Ms. Soon Ling Chin (Consultant, MFD), and was assisted by Mrs. Adams (Senior Resident Representative). Ms. Rogers (OED) attended some of the meetings.

- Vietnam's three-year PRGF arrangement (SDR 290 million) expired on April 12, 2004. Only two reviews were completed, with SDR 124.2 million disbursed. Since the expiration, the Fund has continued to provide analysis and policy assessments on macroeconomic and financial sector issues, supplemented by an active technical assistance program. In addition, the Fund has cooperated closely with the World Bank as it continues its Poverty Reduction Support Credit program, and provided regular assessments to donors in the Consultative Group process.

- In concluding the last Article IV consultation in October 2003, Directors noted that prudent macroeconomic management had provided an environment conducive to growth, and that the transition to a more market-oriented economy and increasing integration into the global economy had been key to poverty reduction. Nonetheless, they cautioned that the transition process was still incomplete, with the authorities facing challenges, especially in reform of state-owned commercial banks and enterprises.

- Vietnam's statistical base has significant limitations for surveillance purposes. STA is providing assistance to address deficiencies in the national accounts, prices, and monetary statistics. Vietnam has become a subscriber to GDDS, with its metadata posted on the official website (Dissemination Standards Bulletin Board) since September 2003.

- Vietnam maintains exchange rate restrictions under the transitional arrangement of Article XIV, Section 2, and a number of restrictions are subject to approval under Article VIII. The capital account is also subject to extensive controls. 


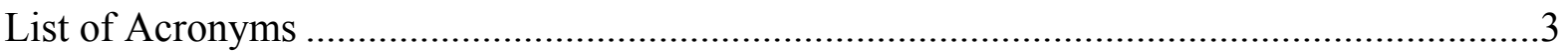

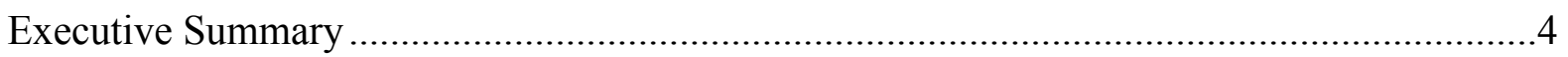

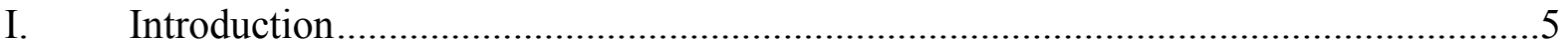

II. Recent Economic Developments and Outlook .........................................................

A. Economic Developments ..................................................................................5

B. Macroeconomic Outlook and Risks ..................................................................

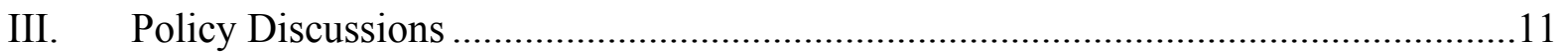

A. Monetary and Exchange Rate Policy ...................................................................11

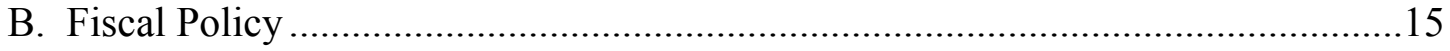

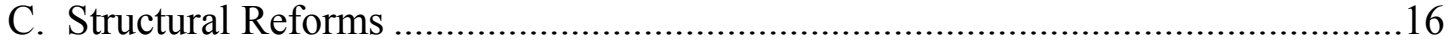

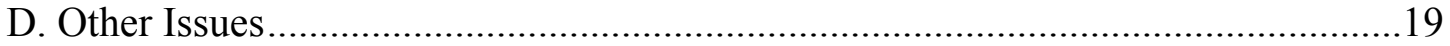

E. Ex Post Assessment of Longer-Term Program Engagement ..................................19

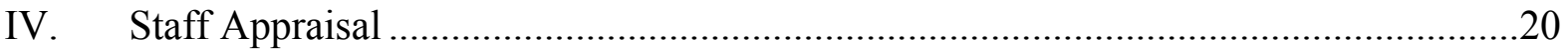

Boxes

1. The Impact of Oil Price Increases on Vietnam's Economy …………...........................

2. Vietnam's WTO Accession: Progress and Prospect...................................................12

3. Monetary Policy Instruments in Vietnam ...................................................................13

Figures

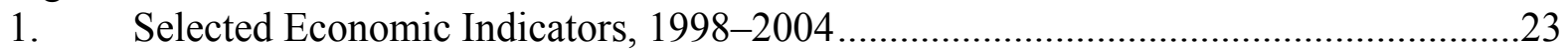

2. External Sector Background, 1998-2004 ……....................................................24

3. Monetary and Financial Indicators, 1998-2004 …………………………….......25

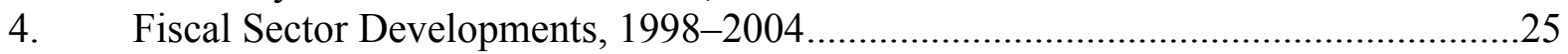

Tables

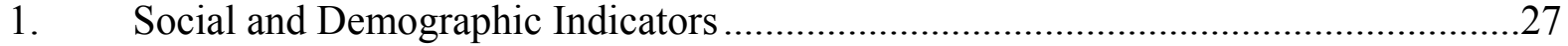

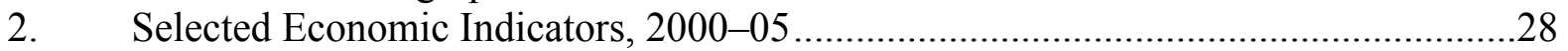

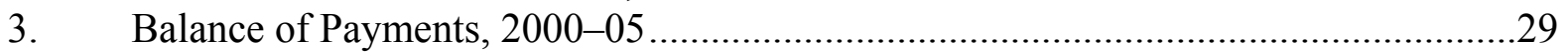

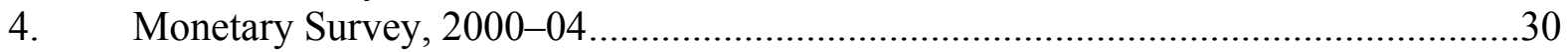

5. Summary of General Government Budgetary Operations, 2000-05 ……...................31

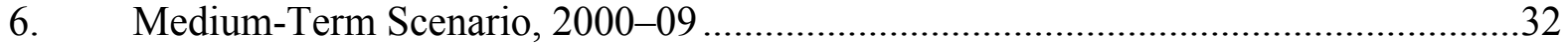

7. Indicators of External Vulnerability, 2000-04 ...........................................................33

Annexes

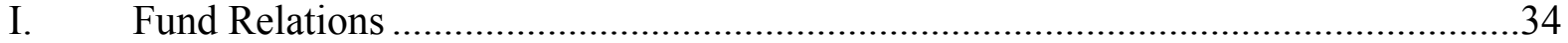

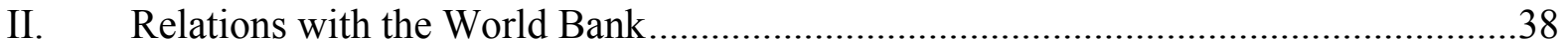

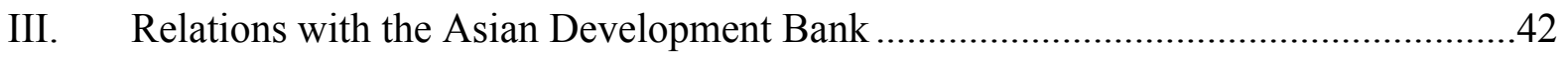

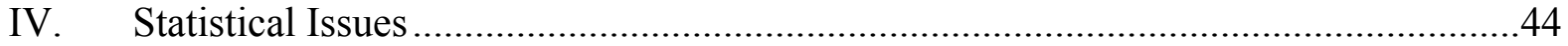

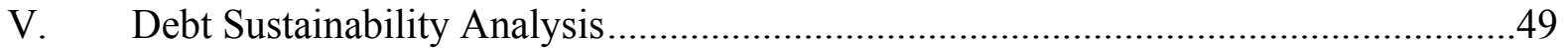

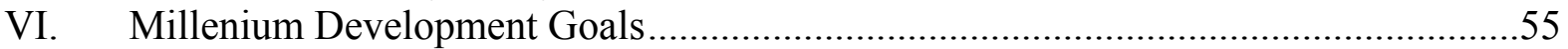




\section{List of Acronyms}

$\begin{array}{ll}\text { AFTA } & \text { ASEAN Free Trade Agreement } \\ \text { AML/CFT } & \text { Anti-Money Laundering/Combating the Financing of Terrorism } \\ \text { ASEAN } & \text { Association of South East Asian Nations } \\ \text { CPRGS } & \text { Comprehensive Poverty Reduction and Growth Strategy } \\ \text { DAF } & \text { Development Assistance Fund } \\ \text { EPA } & \text { Ex Post Assessment } \\ \text { ESAF } & \text { Enhanced Structural Adjustment Facility } \\ \text { FDI } & \text { Foreign Direct Investment } \\ \text { GSO } & \text { General Statistical Office } \\ \text { IAS } & \text { International Accounting Standards } \\ \text { ICOR } & \text { Incremental Capital Output Ratio } \\ \text { MDG } & \text { Millenium Development Goal } \\ \text { MOF } & \text { Ministry of Finance } \\ \text { MPI } & \text { Ministry of Planning and Investment } \\ \text { NIR } & \text { Net International Reserves } \\ \text { NPL } & \text { Non-Performing Loan } \\ \text { NPV } & \text { Net Present Value } \\ \text { ODA } & \text { Official Development Assistance } \\ \text { PRGF } & \text { Poverty Reduction and Growth Facility } \\ \text { SBV } & \text { State Bank of Vietnam } \\ \text { SME } & \text { Small- and Medium-sized Enterprises } \\ \text { SOCB } & \text { State-Owned Commercial Bank } \\ \text { SOE } & \text { State-Owned Enterprise } \\ \text { VAS } & \text { Vietnamese Accounting Standards } \\ \text { VAT } & \text { Value Added Tax } \\ \text { VCB } & \text { Vietcom Bank } \\ \text { WTO } & \text { World Trade Organization }\end{array}$




\section{EXECUTIVE SUMMARY}

\section{Background}

- Economic growth remains strong in 2004, despite the impact of the avian flu outbreak and droughts on agricultural output. Led by strong export performance, real GDP growth of 7-71/2 percent is expected for the year.

- CPI inflation rose sharply to about 10 percent in September 2004, driven by supplyside shocks. Since July, however, food inflation has fallen rapidly, contributing to a decline in annualized monthly inflation to $4 \frac{1}{2} 2$ percent in September.

- Credit growth has accelerated to 36 percent in July 2004. In response, the authorities have raised reserve requirements and also taken a range of administrative and fiscal measures.

- The pace of structural reform in state-owned banks and enterprises has been slow, despite the January 2004 Party Plenum's initiatives to accelerate key reforms.

Key Issues and Staff Recommendations

- The authorities should tighten monetary conditions further if there are signs of second-round effects from the supply-side price shocks. Aside from inflationary considerations, credit growth should be reduced significantly to prevent a further deterioration in banks' asset quality.

- The policy of keeping the dong-US dollar exchange rate and interest rates stable could weaken the reserve position. Moving toward greater exchange rate flexibility would facilitate adjustments to external shocks and rapid structural changes, and allow for a further strengthening of the relatively weak reserve position.

- The pace of structural reforms in state-owned banks and enterprises should be accelerated to sustain economic growth and poverty reduction over the medium term. Equitization of large state-owned commercial banks and enterprises - a key reform measure - should be aimed at transforming their operations to a more commercial basis. ${ }^{1}$

- WTO accession would help sustain export growth and foreign direct investment over the medium term. Vietnam's WTO commitment will also help catalyze other structural reforms.

- Transparency as well as reliability and timeliness of data should be improved, particularly in the areas of balance of payments, fiscal operations, foreign exchange reserves, national income accounts, and state-owned banks and enterprises.

\footnotetext{
${ }^{1}$ Equitization, a form of privatization, involves share sales of a portion of state capital in an enterprise.
} 


\section{INTRODUCTION}

1. The three-year PRGF arrangement expired in April 2004. Although the program had been de facto suspended since late-2002 over the authorities' reluctance to comply with the Fund's safeguards policy, it had achieved a number of successes. Strong output growth and low inflation remained throughout the PRGF period, resulting in further poverty reduction (Table 1), and progress in trade liberalization was impressive. Nevertheless, the pace of reforming state-owned commercial banks (SOCBs) and state-owned enterprises (SOEs) has been slow. Aiming to ensure continued strong growth and poverty reduction, the Communist Party Plenum held in January 2004 called for acceleration in several structural reforms, including initiating the equitization of one of the four large SOCBs, increasing the pace of equitizing major SOEs, and actively pursuing integration into the international economy.

2. The Article IV consultation and EPA discussions provided a timely opportunity to assess policy achievements under the PRGF-supported program and to take stock of Vietnam's challenges ahead. The discussions also took place in the context of rising inflation, which together with rapid credit expansion, poses significant challenges for macroeconomic management.

\section{RECENT ECONOMIC DEVELOPMENTS AND OUTLOOK}

\section{A. Economic Developments}

3. In 2003, real GDP growth remained strong (71/4 percent), led by investment and export growth (Table 2, Figure 1). ${ }^{2}$ Fixed capital formation increased by 15 percent. Exports were robust, mainly benefiting from the U.S.-Vietnam Bilateral Trade Agreement, as well as higher oil prices. Private consumption, which increased by $7-7 \frac{1}{2}$ percent, was also an important contributor to overall growth.

\begin{tabular}{|c|c|c|c|c|c|c|}
\hline \multicolumn{7}{|c|}{$\begin{array}{l}\text { Key Macroeconomic Indicators, 2001-04 } \\
\text { (Percent change, unless noted otherwise) }\end{array}$} \\
\hline & 2000 & 2001 & 2002 & 2003 & 2004 & \\
\hline & & & & \multicolumn{2}{|c|}{ Est. August } & Proj. \\
\hline Real GDP & 6.8 & 6.9 & 7.1 & 7.3 & $\ldots$ & $7-71 / 2$ \\
\hline Fixed capital formation & 10.2 & 10.7 & 12.9 & 14.2 & $\ldots$ & 10.0 \\
\hline Industrial production & 18.4 & 13.7 & 18.8 & 16.9 & 18.3 & $\ldots$ \\
\hline Retail sales & 9.7 & 8.1 & 9.6 & 11.1 & 9.6 & $\ldots$ \\
\hline CPI (average) & -1.6 & -0.4 & 4.0 & 3.2 & $6.91 /$ & $7-8$ \\
\hline Nonfood CPI & 1.2 & 0.8 & -0.2 & 4.1 & $1.51 /$ & $2-3$ \\
\hline Merchandise exports & 25.2 & 4.0 & 11.2 & 19.6 & 26.1 & 22.0 \\
\hline Non-oil & 15.9 & 8.7 & 12.9 & 20.3 & 22.8 & 18.0 \\
\hline Merchandise imports & 34.5 & 2.3 & 22.1 & 27.9 & 22.8 & 19.6 \\
\hline Trade balance (US\$ billions) & 0.4 & 0.6 & -0.9 & -2.5 & -3.0 & -2.5 \\
\hline Current account (percent of GDP) & 2.1 & 2.1 & -1.2 & -4.7 & $\ldots$ & -4.6 \\
\hline
\end{tabular}

4. Growth declined in the first quarter of 2004 but began to rebound in the following months. In the first quarter of the year, agricultural production fell, mainly reflecting the avian flu outbreak and droughts, and manufacturing and construction growth

${ }^{2}$ All GDP figures in this report are based on the authorities' national accounts data. 
slowed since higher world commodity prices — notably steel — caused a delay in investment projects. The impact of these developments was mitigated by buoyant exports led by oil exports (Box 1 on the impact of oil price increases). Since then, agriculture production has recovered and industrial production rebounded.

\section{Inflation, which was moderate in 2003, rose to 10 percent (year-on-year) in}

September 2004 driven by supply shocks. Food prices, which account for about 48 percent of the CPI basket, jumped in early 2004, owing to the avian flu outbreak, droughts, and rising
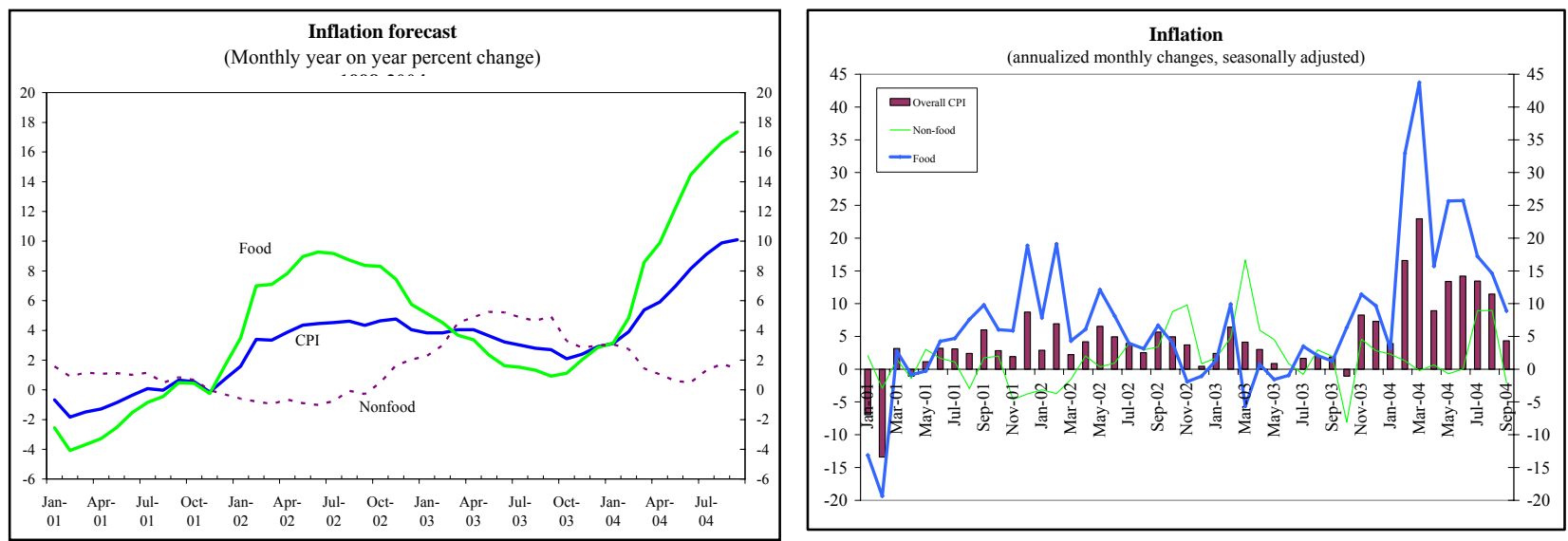

international commodity prices (such as rice). Since July, however, food inflation has fallen rapidly, contributing to a decline in annualized monthly inflation to $4 \frac{1}{4}$ percent (seasonally adjusted) in September. Non-food inflation has remained subdued, averaging only 2 percent during the first nine months of 2004.

\section{Vietnam's overall balance of payments strengthened in $\mathbf{2 0 0 3}$ despite a widened} current account deficit (Table 3, Figure 2). Export growth was outpaced by import growth, especially machinery and equipment driven by strong investment. As a result, the current account deficit widened to $43 / 4$ percent of GDP. The deficit was more than fully financed by capital inflows - a mix of Official Development Assistance (ODA), foreign direct investment (FDI), and a substantial run-down of domestic banks' foreign assets - allowing the State Bank of Vietnam (SBV) to increase international reserves by US $\$ 1.9$ billion, with

\begin{tabular}{|c|c|c|c|}
\hline \multicolumn{4}{|c|}{$\begin{array}{l}\text { Official Reserves, 2002-04 } \\
\text { (In millions of U.S. dollars) }\end{array}$} \\
\hline & 2002 & 2003 & $20041 /$ \\
\hline Gross international reserves & 3,692 & 5,619 & 5,766 \\
\hline Net international reserves & 2,915 & 4,683 & 4,858 \\
\hline & \multicolumn{3}{|c|}{ (Change during the period) } \\
\hline Gross international reserves & 305 & 1,927 & 147 \\
\hline Net international reserves & 401 & 1,768 & 175 \\
\hline
\end{tabular}
the stock reaching US $\$ 5.6$ billion (about 91/2 weeks of imports ) at end-2003. 


\section{Box 1. The impact of Oil Price Increases on Vietnam's Economy}

\section{The oil sector plays an important role in the economy.}

- Vietnam is a net exporter of oil. It exports about 16-18 million metric tons of crude oil per year, accounting for almost 20 percent of its total annual exports. Since Vietnam has no oil refineries, it imports some 10 million metric tons of petroleum products per year, about 10 percent of its total imports. The net oil export proceeds amount to US\$1.3-1.4 billion, close to 4 percent of GDP per year.

- Revenues from crude oil exports amount to roughly 5 percent of GDP; import duties, VAT and excises on imported petroleum products add another 1-2 percent of GDP. The government typically adjusts import duties on petroleum products in response to oil price fluctuations to stabilize the domestic prices.

- Petroleum product prices are administered in Vietnam. They represent 3 percent of the CPI basket, but indirectly affect an additional 3 percent of the basket through electricity and transportation costs.

\section{Oil price increases have had an important macroeconomic impact.}

- An increase in net oil exports for 2004 as whole is estimated at US\$490 million (1.2 percent of GDP). Net oil exports increased by US\$350 million ( 0.9 percent of GDP) in the first eight months of the year, as crude oil exports and petroleum product imports increased by 40 and 24 percent $(\mathrm{y} / \mathrm{y})$, respectively.

- A net fiscal impact of 1.5 percent of GDP is expected in 2004. Revenues from crude oil exports are projected to exceed the budget target by 2.6 percent of GDP. Import duties on petroleum products have been reduced to virtually zero since end-May, causing revenue losses of 0.7 percent of GDP. Adjustments in domestic petroleum prices fell short of world price increases, likely requiring subsidies of 0.4 percent of GDP in 2004. SOEs have been advised to absorb a part of higher input prices through lower profit margins, but the revenue impact is difficult to estimate.

- Administered petroleum product prices were increased in February and again in June 2004, adding almost 2 percentage points to 12-month inflation.

Future oil price increases would improve the external current account balance and increase fiscal leeway, but may threaten domestic price stability. Based on staff estimates, an additional US\$ 5 per barrel increase in the world oil price would:

- Bring additional net oil export proceeds of US\$290 million, or about 0.8 percent of GDP.

- Increase crude oil revenues by about 0.9 percent of GDP. Given that import duties can not be adjusted downward much further, total revenues would increase commensurately. With regulated prices at their current level, subsidies would increase by about $1 / 2$ percent of GDP annually.

- Raise 12-month inflation by about 0.7 percentage points, assuming full pass-through of higher oil prices. 
7. In the first eight months of 2004, exports continued to grow rapidly while import growth decelerated. Exports increased by 26 percent, mainly driven by primary commodities, especially crude oil, as well as textiles and garments. Import growth slowed to 23 percent, reflecting a decline in imports of machinery and equipment after the completion of some major investment projects. Despite strong

\begin{tabular}{|lccc|}
\hline \multicolumn{4}{|c|}{$\begin{array}{c}\text { Contribution to Export Growth in Jan. - Aug. 2004 } \\
\text { (In percent) }\end{array}$} \\
\hline & Weight & Growth rate & $\begin{array}{c}\text { Contribution to } \\
\text { growth }\end{array}$ \\
\hline Commodity exports & 42 & 29 & 12 \\
Of which: crude oil & 19 & 40 & 8 \\
Non-commodities & 39 & 21 & 8 \\
Of which: garments & 20 & 16 & 3 \\
\multicolumn{1}{c}{ footwear } & 11 & 18 & 2 \\
Other exports & 19 & 31 & 6 \\
Total & 100 & 26 & 26 \\
\hline
\end{tabular}
net oil export proceeds, international reserves increased only moderately.

8. Vietnam's real effective exchange rate depreciation in 2003 was reversed in 2004 (Figure 2). Despite only a 13/4 depreciation in the dong-US dollar exchange rate, the depreciation of the US dollar against other major currencies resulted in a 6 percent real effective depreciation of the dong in 2003. While the dong-US dollar exchange rate has been kept virtually unchanged since early 2004, a sharp rise in inflation has resulted in a 6 percent appreciation of the dong in real effective terms. Nevertheless, Vietnam's external competitiveness is likely to remain adequate provided that the supply-side price shocks and the civil service wage increase in October 2004 do not lead to widespread wage increases.

9. Credit growth has accelerated, and monetary aggregates continue to grow rapidly (Figure 3, Table 4). Credit growth accelerated to 28 percent at end-2003 and further to 36 percent in July 2004 . The sharp increase in credit growth in 2004 was led by the state sector. Broad money growth rose to 25 percent in 2003 and stayed at about the same level in the first seven months of 2004, reflecting the ongoing monetization. Policy interest rates remained unchanged; the discount, refinancing, and base rates have been fixed since end-2003 at 3 percent, 5 percent, and 7.8 percent, respectively. However, short-term

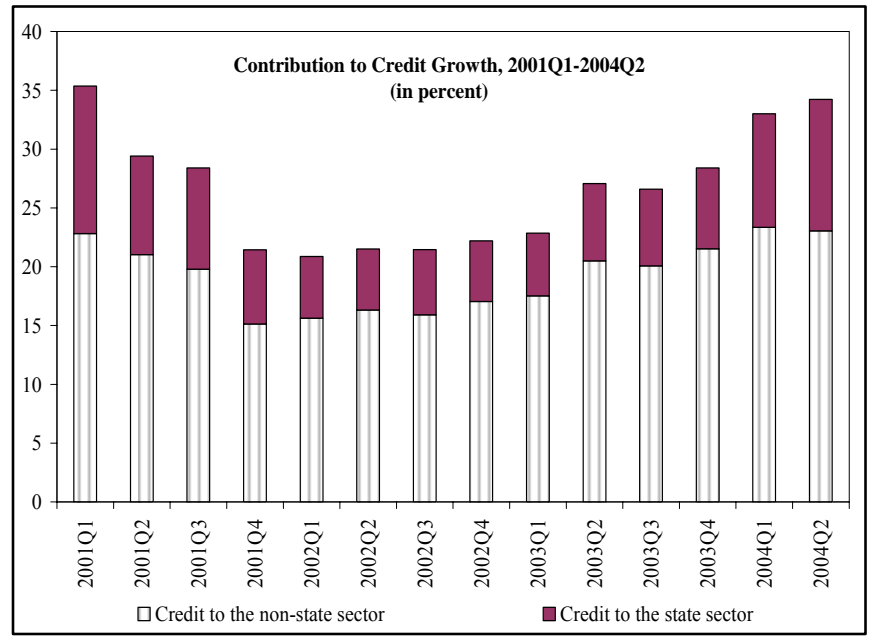
dong deposit and lending rates increased slightly in recent months.

10. The authorities have taken a series of monetary and administrative measures in response to rising inflation and rapid credit growth. In early July 2004, reserve requirements on dong and foreign currency deposits were increased from 2 percent and 4 percent to 5 percent and 8 percent, respectively. In addition, the government cut the tariffs on petroleum and steel products, and the Prime Minister issued a directive in August 2004 calling for a cut in government recurrent expenditure and lending by SOCBs, a strengthening of enterprises' efforts to reduce production and distribution costs, and a tightening of price control enforcement. 
11. The fiscal stance is estimated to have slightly loosened in 2003 (Table 5, Figure 4). Despite reduced tariffs on imported petroleum, revenues increased by more than 1 percentage point of GDP relative to 2002, aided by strong domestic demand and greater proceeds from sales of land-use rights. Expenditure grew even more, reflecting a 38 percent wage increase, higher spending on education, and increased capital spending and net lending. ${ }^{3}$

\section{The fiscal outturn through the first half of $\mathbf{2 0 0 4}$ was better than budgeted.}

Revenues outperformed budget expectations, reflecting higher oil prices. Recurrent spending remained in line with the budget despite exceptional outlays for avian flu and oil price subsidies. Capital spending was also on track, but domestically-financed on-lending reached only 30 percent of the budget target by mid-year.

\section{B. Macroeconomic Outlook and Risks}

13. For 2004 as a whole, economic growth and the external current account are likely to be broadly unchanged from 2003, with inflation falling toward the end of the year and the budget deficit narrowing. Real GDP growth in 2004 is projected to remain at $7-71 / 2$ percent, aided by a recovery in agriculture and a pickup in industrial production in the second half of the year. Inflation is expected to fall to $9 \frac{1}{2}$ percent (year on year) by end-2004 under a benign scenario in which food prices decline in the final quarter of the year

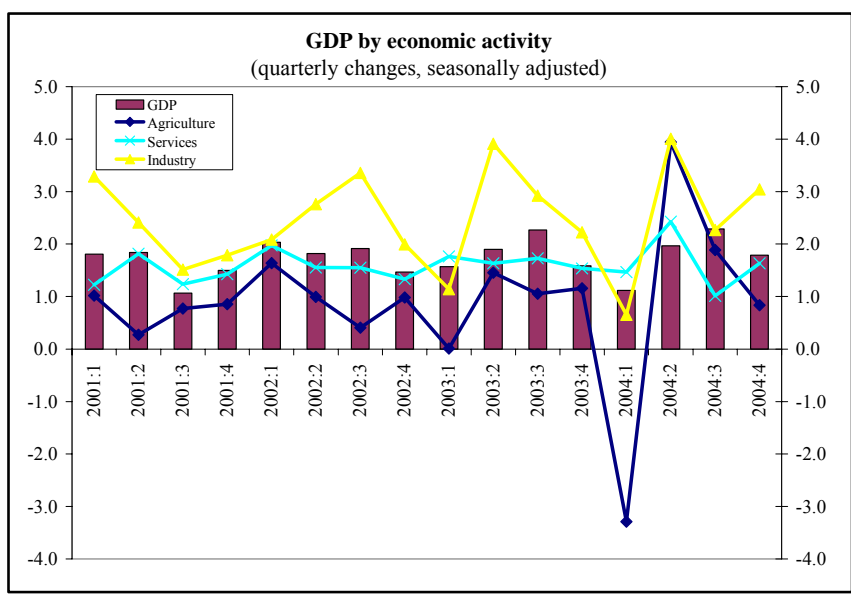
and the announcement of an increase in civil services wages in October does not trigger sizable wage increases in the rest of the economy. As textile quotas become binding in the latter months of the year, export growth is likely to slow, with the current account deficit in 2004 projected to remain at 43/4 percent of GDP. While ODA inflows would remain strong,

${ }^{3}$ On-lending takes two forms: ODA-funded on-lending, recorded in the budget and administered by the Development Assistance Fund (DAF); and domestically-funded lending, not recorded in the budget but financed and approved by the DAF. 
FDI inflows would decline, in part reflecting investors' wait-and-see attitude relating to the uncertain timing of Vietnam's WTO accession. Reduced short-term capital inflows would allow for only a modest accumulation of international reserves. Initiatives to tighten projects' eligibility requirements for domestically-financed on-lending and reduced expenditure are expected to lead to a significant fiscal tightening compared to 2003.

14. Although Vietnam will face some external challenges in 2005, the overall growth outlook is projected to be broadly unchanged, with inflation expected to decline. A projected decline in some commodity prices (such as rice) and the elimination of textile quotas for WTO members - which could expose Vietnam to greater competition - could lead to a significant decline in export growth and a widening of the current account deficit. While the deficit is expected to be covered by ODA financing and FDI inflows, there would be limited scope for reserve accumulation without exchange rate or other policy adjustments. With slower export growth offset by a rebound in agricultural production and a modest fiscal stimulus, economic growth is projected to remain at about $7-7 \frac{1}{2}$ percent. If world commodity prices decline as projected and the avian flu remains under control, inflation would fall to around 5-6 percent.

15. Under the staff's baseline scenario, the medium-term outlook appears favorable (Tables 6-7). Real GDP growth is expected to average 7 percent per year, supported by export expansion (notably of manufactures), reflecting in part the assumption of a successful WTO accession by end-2005. The external position is likely to remain manageable, with current account deficits declining gradually and a steady increase in capital inflows driven by strong FDI following WTO accession leading to an accumulation of reserves.

\section{The outlook for 2005 and beyond,} however, is subject to several downside risks. In the short run, measures taken so far could be insufficient to substantially reduce credit growth and contain inflation. This, together with the possibility of higher-thanexpected food prices, could reverse the downward trend in inflation and fuel inflationary expectations. Over the medium term, growth, which has been increasingly supported by investments of uncertain quality (as evidenced by a steadily rising ICOR since 1992), could fall short of the projected level if the efficiency of

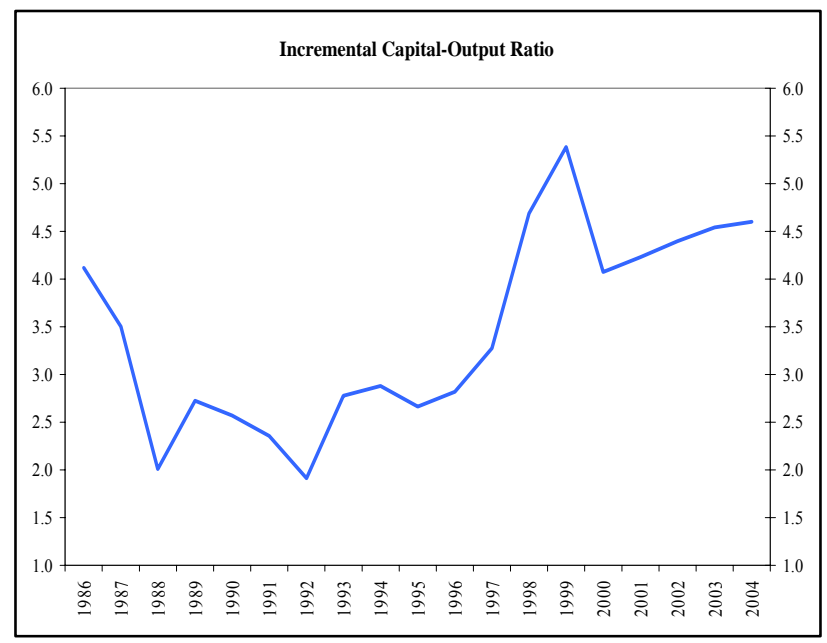


investment does not improve. Prolonged delays in WTO accession could also threaten growth prospects (Box 2). Moreover, public debt sustainability could be threatened if SOCB performance does not significantly improve. ${ }^{4}$

\section{Policy Discussions}

17. The discussions focused on rising inflation, rapid credit growth, and the policy priorities needed to maintain strong growth over the medium term. The staff urged the authorities to take further measures if inflationary expectations become entrenched and credit growth does not decline significantly. While agreeing with this, the authorities' near-term policy priority remains achieving the growth target set under the five-year plan (2001-05). The staff emphasized that beyond the short term, sustained economic growth and lasting poverty reduction would hinge on the pace of structural reform, aimed at improving efficiency of the state-owned sector, ensuring public debt sustainability, and encouraging private investment.

\section{A. Monetary and Exchange Rate Policy}

18. The SBV's monetary policy is guided by a number of often conflicting economic policy objectives, including economic growth, price and currency stability, and financial system stability. The SBV's ability to respond to inflationary shocks is further constrained by its weak and underdeveloped indirect instruments and the dominance of SOCBs, which frequently operate based on non-commercial objectives (Box 3). Against this background, the authorities have taken a range of administrative and fiscal measures to supplement monetary policy actions (as discussed above) in response to the increase in inflation.

19. The SBV's current policy is to stabilize the exchange rate while keeping interest rates unchanged, with foreign exchange reserves adjusting as needed. The authorities regarded the high inflation as reflecting temporary factors, and not loose monetary policy, and expected inflation to fall in 2005 . As a result, the SBV expected only a modest reserve accumulation in 2004, but did not regard the current reserve position as a concern given the large build-up in 2003.5

20. The staff encouraged the SBV to tighten monetary conditions further if there are signs of second-round effects from the supply-side price shocks, which could be reflected in pressures on foreign exchange reserves and wages. The staff highlighted that increasing the discount and refinancing rates would reinforce the authorities' policy goal of containing

\footnotetext{
${ }^{4}$ For details, see Annex V on public debt sustainability analysis.

${ }^{5}$ Based on data through end-July, gross reserves have increased modestly since end-2003.
} 


\section{Box 2. Vietnam's WTO Accession: Progress and Prospect}

The prospect for Vietnam to become a WTO member by 2005 - the publicly announced government objective_remains unclear, despite strong efforts on the part of the Vietnamese government and significant progress in the accession negotiations since May 2003. At the conclusion of the $8^{\text {th }}$ WTO Working Party (WP) meeting on Vietnam's accession in June 2004, the WP members stated that an agreement with Vietnam is much closer than at the December 2003 meeting. However, considerable work still remains in continuing to negotiate market access and other terms of Vietnam's membership, in obtaining further clarification of Vietnam's regulations and policies, and in Vietnam's putting in place the necessary legislation (e.g., the Law on Competition, the Amended Commercial Law, the Common Investment Law). Vietnam concluded a bilateral trade agreement with the EU, its largest trading partner, in October. The next WP meeting will be held in December 2004, and significant progress by then is critical for an accession by end2005.

Achieving an early WTO accession is very important to Vietnam. Specifically,

- $\quad$ Market access of Vietnam's exports. As a WTO member, Vietnam would be able to benefit from the eventual phasing out of quotas on textile and garments exports under the WTO Agreement on Textile and Clothing, scheduled to begin in January 2005. Textile and garments have been the major driver of Vietnam's export growth, accounting for nearly 20 percent of its total exports in 2003, and any delay in accession would represent an important missed opportunity.

- Investors' confidence in Vietnam. WTO accession would help boost foreign direct investment by unlocking additional investments that have been awaiting WTO accession.

- $\quad$ Reform momentum. The process of the WTO membership negotiation and the eventual accession have been considered by the reformists within the government as well as the donor community as an important mechanism to lock in and catalyze structural reforms through external commitments. 


\section{Box 3. Monetary Policy Instruments in Vietnam}

Monetary policy implementation at the SBV has partially evolved from one of heavy reliance on direct credit control to the more frequent use of indirect instruments. Interest rates on dong deposits and lending in both dong and foreign currency are liberalized, but the SBV still imposes interest rate ceilings on enterprises' foreign currency deposits. Open market operations (OMOs) were introduced in 2000, and their use has increased since. The SBV provides two standing facilities, the discount facility and the refinancing facility.

- Through the discount facility, credit institutions can access SBV funds subject to quotas, and the maximum term of drawing is 91 days.

- The refinancing facility is a collateralized lending facility.

The discount and refinancing facility rates form the lower and upper bands of an interest rate corridor that is set by the SBV and known to the market. The OMO rate is regarded by the SBV as an indication of the monetary policy stance, but is not the only indicator.

The SBV also announces a base rate, which was introduced in 2000 to provide a reference rate for commercial banks' lending rates. However, the relationship between the base rate and other interest rates has been very weak.

The SBV continues to use less

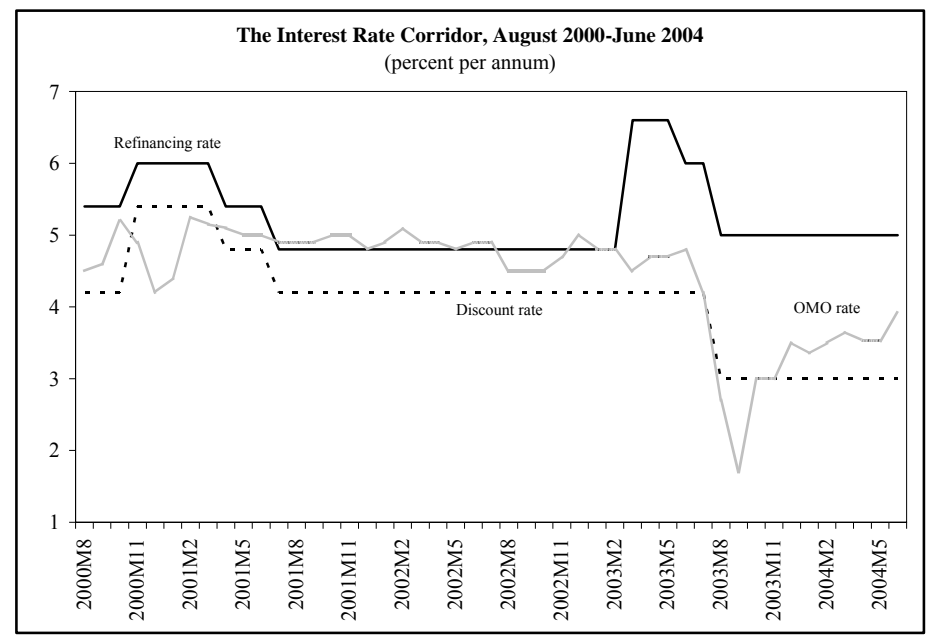
market-based monetary policy instruments such as reserve requirements considered by the SBV to be the most effective policy instrument. Reserve requirements are differentiated by bank, currency, and maturity. The SBV pays interest on required reserves in dong and on excess reserves in foreign currency. 
credit growth (see below) and fighting inflation. While noting the authorities' concern that raising interest rates could adversely affect short-run growth and weaken the balance sheets of vulnerable SOEs, the staff argued that an interest rate increase would help contain inflationary expectations and safeguard the quality and sustainability of long-run growth. The authorities agreed that maintaining macroeconomic stability was a priority, and signaled a willingness to tighten monetary conditions further if there are signs that inflationary expectations are becoming entrenched. However, the SBV preferred to rely on reserve requirements rather than interest rates, maintaining that with indirect instruments underdeveloped, ${ }^{6}$ the transmission mechanism of interest rates on inflation was both weak and slow.

\section{Aside from inflationary considerations, the authorities broadly shared the staff's} view that a significant reduction in credit growth was needed, given uncertain loan quality and its implications for bank balance sheets. The authorities emphasized that rapid credit growth was needed to support the government's growth objectives, but regarded the current rate as too high. The SBV argued that recent policy actions-including the doubling of reserve requirement ratios, and the SBV's instruction to SOCBs to curb their lending to inefficient investment projects - should bring about a reduction in credit growth in 2004 . However, the staff saw no clear sign that credit growth had fallen, and urged the SBV to take further measures if credit growth does not decline significantly.

22. The staff emphasized the risks of a de facto pegged exchange rate regime. The authorities stated their intention to keep the dong-US dollar exchange rate broadly stable in the near future, with the SBV selling foreign exchange to ensure that foreign exchange demand would be met. While noting that the policy of keeping the rate stable may have helped anchor inflationary expectations, the staff underscored the risk that restricting exchange rate movements within a very narrow trading band could create the perception of an implicit exchange rate guarantee and reduce the sensitivity of market participants to exchange rate risks, thereby leading to excessive

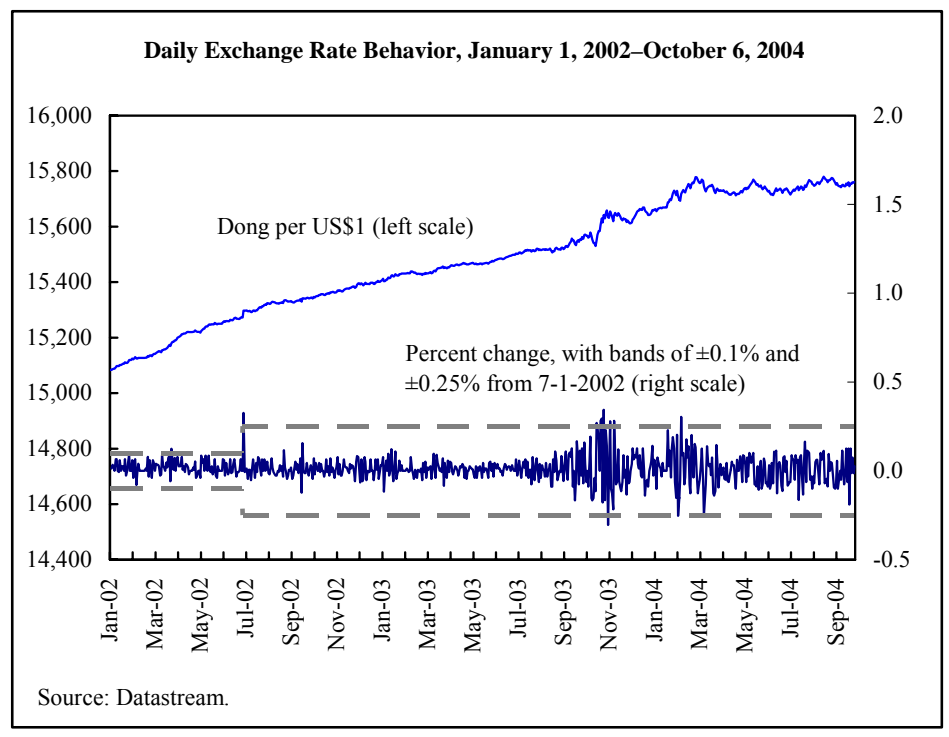

${ }^{6}$ For example, the government securities market is highly segmented and illiquid, with a limited range of maturities. 
foreign exchange exposure in the economy. The staff urged the authorities to move toward greater exchange rate flexibility, both intra-day and over time, and to limit intervention to addressing temporary disorderly conditions. Introducing greater flexibility would also facilitate adjustments to external shocks and rapid structural changes, and allow for a further strengthening of Vietnam's relatively weak reserve position.

\section{B. Fiscal Policy}

23. The staff noted that the authorities were pursuing a more cautious fiscal stance in 2004 than budgeted. The authorities agreed that revenue was on pace to exceed budget estimates, but were less optimistic than the staff regarding the amount of excess revenues, projecting the deficit including net lending to exceed $3 \frac{1}{2}$ percent of GDP. The staff welcomed the authorities' intention to keep capital spending and on-lending close to the budgeted levels, given their uncertain quality.

\section{Annual budget targets for $\mathbf{2 0 0 5}$ and beyond should be set consistent with} medium-term public debt sustainability. The authorities are currently targeting a budget deficit (including net lending) in 2005 of about 5 percent of GDP. The staff argued that the 5 percent deficit target could be considered an upper bound estimate for a sustainable fiscal stance based on illustrative projections of the public debt (Annex V), and encouraged the authorities to reevaluate the 2005 fiscal stance and formulate annual budget targets beyond based on a thorough assessment of the quality of SOCBs' balance sheets. While a modest fiscal stimulus in 2005 could be appropriate to offset an expected significant decline in export growth, the staff urged the authorities to reduce the 2005 budget deficit target if inflation remains high due to demand pressures.

\section{The authorities and staff agreed that revenue pressures were likely to increase} over the medium term, arising mainly from trade liberalization and stagnating oil revenues. Reforms aimed at addressing structural weaknesses of the tax system might add to the revenue pressures. ${ }^{7}$ The authorities noted their intention to maintain a revenue-to-GDP ratio of 21-22 percent through improvements in tax administration, and to extend self-assessment to additional taxpayers by January 2005, as recommended by a recent FAD TA mission. The staff cautioned, however, that tax administration measures alone would be unlikely to compensate for the projected revenue losses, and encouraged the authorities to begin identifying possible tax measures which could be applied when needed.

${ }^{7}$ Structural deficiencies include cascading features and restrictive rules on deductible expenses in determining taxable income. Removing these deficiencies recommended by a recent FAD TA mission could lead to a revenue loss. 
26. The authorities' wage reform will align public wages closer to the market levels. Wages in the higher ranks of the civil service have not kept pace with wage growth in the private sector. Effective October 2004, the government has overhauled the pay scale for civil servants to increase the wage spread, with the 30 percent pay increase on average financed by a combination of retrenchment, cuts in non-wage recurrent expenditure, and recourse to offbudget revenues retained by spending units. The staff welcomed the widening of the wage spread but warned that cuts in non-wage recurrent expenditure would exacerbate the existing imbalance between recurrent and capital outlays. Ministry of Finance (MOF) officials shared the staff's concern about the low level of recurrent expenditures.

27. The staff recommended that the price subsidies, used as a measure to fight inflation, be temporary to minimize distortions and adverse effects on growth. The authorities cut tariffs on petroleum and steel products and refrained from bringing domestic petroleum prices in line with world prices. They argued that these measures were needed to anchor inflationary expectations, and added that since Vietnam is a net exporter of oil, most of the fiscal cost has been offset by windfall oil revenues.

28. The staff welcomed the important steps taken by the authorities to streamline on-lending activity, but underscored that loan quality remains uncertain. A recent decree narrows the list of enterprises eligible for on-lending, brings interest rates more in line with market levels, and limits state support to 85 percent of project costs. The authorities noted that domestically financed on-lending would remain constant in nominal terms over the medium term, implying a steady decline in relation to GDP.

\section{Structural Reforms}

\section{Financial Sector Reform}

29. The SOCBs, which account for about $\mathbf{7 0}$ percent of the banking system's total assets, are the strategic weak point among Vietnam's economic institutions, burdened with low asset quality, multiple mandates from the government, significant undercapitalization, and the poor capacity of credit assessment and risk management. While the authorities have taken some initiatives, including the issuance of credit manuals by all SOCBs, progress in SOCB reform has been slow.

30. The staff recommended that the authorities develop a renewed comprehensive reform strategy for the SOCBs. Such a strategy should include decisive steps to ensure that lending is based on a strictly commercial objective and sound appraisals of repayment capacity, banks are recapitalized to rebuild balance sheets, and nonperforming loans (NPLs) are resolved and revalued. These steps need to be accompanied by measures to improve governance, with the MOF exerting a more active ownership role and significantly strengthening the SBV's supervision in line with the recommendations of recent MFD TA.

31. As a first step, the staff urged the authorities to obtain a more accurate assessment of the quality of banks' balance sheets, a prerequisite for effective banking supervision. The authorities acknowledged that banks are likely to be showing an unrealistic 
level of NPLs, and that current loan classification practices do not accurately reflect customers' ability to repay debt as well as their potential risk. As a result, current provisioning practices are regarded as an inaccurate reflection of true capital needs. ${ }^{8}$ In April 2004, the SBV launched an initiative to obtain financial indicators of the banks' large borrowers as a step toward obtaining a more accurate assessment of the SOCBs' balance sheet problems. However, the SBV has made little progress under this initiative, and continues to have few concrete indicators of the true quality of banks' balance sheets and the size of their NPLs. The staff urged the authorities to accelerate progress in this area, and put in place a more thorough and regular reporting framework for monitoring banks' financial performance.

\section{The staff emphasized the importance of the initiative to equitize Vietcom Bank (VCB), one of the large state-owned banks, as a precedent for SOCB restructuring. ${ }^{9}$} This initiative could provide impetus to reform provided that the result is stronger governance, greater transparency, and a shift in the bank's operations to a more commercial basis. The equitization plan, originally scheduled to be submitted to the Prime Minister by end-June 2004, has not yet been finalized, but the authorities indicated that it would likely entail a sale of shares, possibly through public auction, with the government retaining a sizeable majority shareholding. The staff recommended that the equitization process be carefully designed to include a thorough assessment of the bank's asset quality, fair and transparent share sales procedures, and clear NPL resolution and recapitalization plans. International experience with state bank reform has shown that the active involvement of foreign strategic partners can be an effective way to improve the performance of state-owned banks, and the staff urged the authorities to consider selling a large share of the VCB to foreign strategic investors. The authorities noted that they would consider the staff's recommendations in developing a concrete equitization plan.

\footnotetext{
${ }^{8}$ The staff's highly tentative estimates indicate that the capital needed to bring SOCBs to solvency is about 15 percent of GDP at end-2003.

${ }^{9}$ Plans to equitize Mekong Housing Bank, a small SOCB, have been underway for some time with the assistance of the IFC, and some progress has been made toward preparing this bank for sale to foreign strategic partners.
} 


\section{SOE Reform}

33. Restructuring of SOEs continues at a slow pace. Plans to restructure large SOEs are being prepared, but are not expected to be finalized before end-October 2004.

Restructuring of small- and medium-sized SOEs remains sluggish, and the authorities' target of restructuring over 1,000 enterprises by end-2004 looks out of reach. The authorities noted that several initiatives are underway, including the issuance in August 2004 of a decree on state-owned enterprise classification to reduce the number of strategic sectors to remain under full state ownership, a process for assessing SOEs and assigning performance ratings with the first ratings expected around the second half of 2005, and a new decree to be issued shortly to improve the SOE equitization process. ${ }^{10}$ While welcoming these initiatives, the staff recommended that plans to equitize large SOEs be designed carefully to increase commercial incentives for managers and improve performance. Both the authorities and staff agreed that the new enterprise rating system should lead to improved operations and oversight of loss-making enterprises over time, but will need to be followed by strict enforcement of timely reporting requirements, with the MOF taking the lead role in identifying problem sectors and enterprises.

\section{Private Sector Developments}

34. The authorities considered that the amendment to the Land Law issued last year, yet to be implemented, is a key step facilitating further development of the private sector. They also explained that significant progress has been made in eliminating regulations that discriminate against privately-owned firms, and supporting small- and medium-sized enterprises (SMEs). The staff agreed that the full implementation of the Land Law would speed up the registration of land and its allocation to private businesses, but pointed out that with SOE reform lagging, private enterprises' access to land will still be limited, constraining private investment. The staff welcomed plans to unify the enterprise law with the SOE law and the domestic investment law with the foreign investment law, which could lead to an even playing field for all types of enterprises.

\section{Trade Liberalization}

35. The authorities reiterated their intention to achieve WTO accession in 2005, which is crucial to sustaining economic growth in the medium term. The staff commended Vietnam's significant trade liberalization in recent years, and expressed strong support for its

\footnotetext{
${ }^{10}$ The decree would aim to streamline the valuation procedures for enterprises, clarify the responsibilities of managers and supervisors, and increase the shares which would be sold publicly through public auction rather than internally.
} 
WTO accession objective and other efforts to promote free trade in the region as an ASEAN member (e.g., ASEAN-China free trade area initiative). The authorities reported that active preparations, such as harmonization of domestic legislation with WTO principles, were being made in the run up to the next WTO working party meeting scheduled for late 2004, but explained that the achievement of WTO accession would also hinge on conditions set by the negotiating counterparties. The staff noted that significant steps would need to be taken in order to secure WTO membership in 2005 and delays would place Vietnam's export industry, especially textiles and garments, at a significant disadvantage relative to its competitors, and would also affect FDI inflows.

\section{Other Issues}

36. Vietnam should improve transparency as well as reliability and timeliness of data. Improvements are particularly needed in the areas of balance of payments, fiscal operations, foreign exchange reserves, national income accounts, and state-owned banks and enterprises. The authorities noted that they have taken steps, including the new Statistics Law passed in January 2004, which would improve data collection by strengthening the coordination among ministries and government agencies. The staff encouraged the authorities to improve the timeliness of data provision to the IMF and to make more economic and financial data (including international reserves and the banking data) available to the public. The authorities and staff agreed that further TA is needed to help address these weaknesses.

\section{The staff encouraged the authorities to eliminate remaining exchange} restrictions to accept the obligations of Article VIII of the Fund's Articles of Agreement. This will facilitate Vietnam's WTO accession. The authorities reiterated their intention to accept Article VIII obligations and expressed interest in Fund TA to revise the country's foreign exchange restrictions law, which is an important step in Vietnam's preparation to accept Article VIII obligations.

38. The authorities are committed to establishing an effective regime for AntiMoney Laundering and Combating the Financing of Terrorism (AML/CFT) in line with the recommendations of an MFD TA mission in December 2003. The staff underscored the importance of avoiding further delays in the issuance of the AML Decree, which has already been postponed to early 2005 .

\section{E. Ex Post Assessment of Longer-Term Program Engagement}

39. The staff discussed with the authorities the EPA report of Vietnam's longerterm program engagement with the Fund. The authorities welcomed the report, which they regarded as a candid assessment of the limitations and issues in developing and implementing the ESAF and PRGF programs. The authorities provided the following specific observations:

- The authorities emphasized their ownership over the reform program, arguing that from the beginning the government, the Fund, and the World Bank all agreed on the main 
direction of reform and the essential elements required to ensure high and sustainable growth. This commitment was reflected in Vietnam's continued reform progress despite the de facto suspension and expiration of the PRGF program.

- The authorities argued that Fund conditionality should have better reflected actual conditions in Vietnam and been more flexible in adjusting to implementation challenges. In their view, this was particularly evident in the disagreements leading to the suspension of the ESAF and PRGF programs; they regarded the Fund's call for a combination of rapid quota elimination and tariff reduction during the ESAF program as in conflict with WTO principles and an impediment to their negotiations on multilateral and bilateral trade agreements, and the safeguards requirements as outside the original program commitments and incompatible with the Vietnamese legal framework. In some cases, such as SOE reform, the authorities argued that the program's goals were too ambitious from the start, but they nevertheless agreed to them to obtain program approval.

- The authorities emphasized the importance of the Fund's policy advice despite the PRGF program's suspension and expiration. Given the high level of financial support from the World Bank and other donors, the authorities had never regarded access to Fund resources as a main reason for Vietnam's entering into program engagements with the Fund. Rather, the benefit to Vietnam was access to the Fund's policy advice and TA, which they argued had assisted Vietnam considerably in macroeconomic stabilization, creating conditions for high and sustainable economic growth, and accelerating structural reforms. Given this, the authorities argued that the EPA report may have been too pessimistic concerning the loss of Fund influence following the suspension of the PRGF program.

\section{StAFF ApPraisal}

40. In recent years, Vietnam has succeeded in maintaining strong economic growth and low inflation and achieving further poverty reduction, supported by favorable macroeconomic conditions and increasing integration with the world economy facilitated by trade liberalization.

41. The near-term economic outlook is favorable, provided that the authorities can contain inflationary expectations. Economic growth has rebounded following the slowdown in the first quarter of 2004, and growth for 2004 as a whole is projected to be 7$7 \frac{1}{2}$ percent. Inflation would fall by end-2004 as the impact of the supply shocks subsides. The current account deficit is manageable, financed by a combination of ODA and FDI inflows. Lower short-term capital inflows, however, would allow for only a modest accumulation of international reserves in 2004.

42. Second-round effects from the supply-side price shocks are a potential risk. The authorities have taken monetary policy actions supplemented by a number of administrative and fiscal measures, but the effectiveness of these measures has yet to be seen. The staff 
encourages the SBV to tighten monetary conditions if there are signs of the second-round effects. In particular, higher interest rates would reinforce the authorities' policy goal of reducing credit growth and safeguard the quality and sustainability of long-run growth.

43. Credit growth should be reduced significantly in light of uncertain loan quality and the banks' weak balance sheets. Although the significant increase in the reserve requirement ratios has reduced liquidity in the banking system, the SBV should take further measures if the pace of the credit growth does not fall significantly. Maintaining rapid credit growth to meet the short-term growth target could lead to mounting quasi-fiscal liabilities, which could threaten fiscal sustainability and long-term growth.

\section{The staff encourages the authorities to move toward greater exchange rate}

flexibility, which would facilitate adjustments to external shocks and rapid structural changes and allow Vietnam to further strengthen its modest reserve position. Increased exchange rate flexibility also encourages market participants to manage exchange rate risks, thereby avoiding excessive foreign exchange exposure in the economy. The staff calls for a more rapid build up of international reserves by limiting foreign exchange intervention to addressing disorderly conditions.

45. The staff commends prudent fiscal management in 2004, with the budget deficit including net lending expected to fall significantly below the targeted level. The staff welcomes the authorities' intention to save a large part of revenue overperformance while keeping capital spending and on-lending close to the budgeted levels. Although price subsidies used to fight inflation are mostly financed by windfall oil revenues, they should be temporary.

46. Annual budget targets should be set consistent with medium-term public debt sustainability. While the decision to streamline on-lending activity is an important step in the right direction, the staff recommends that annual budget targets for 2005 and beyond be adjusted depending upon the size of fiscal costs of the banking sector restructuring. The staff also urged the authorities to reduce the 2005 budget deficit target if inflation remains high due to demand pressures. With further trade liberalization and stagnating oil revenues adding revenue pressures, the authorities are encouraged to begin identifying possible tax measures in addition to on-going tax administration measures to achieve their goal of maintaining revenue at 21-22 percent of GDP.

47. Sustaining strong growth and poverty reduction over the medium term hinges on the pace of structural reforms in a number of key areas. These include restructuring of SOCBs and SOEs, improving the private sector investment climate, securing WTO accession, and enhancing governance and transparency of policy making.

48. SOCBs are an important source of vulnerability in the economy, given their dominance and uncertain asset quality. The authorities' decision to equitize the VCB is a welcome development and could provide impetus to SOCB reform provided that the equitization ultimately shifts the bank's operations to a more commercial basis. In light of 
country experiences, which indicate the importance of the active involvement of foreign strategic partners in improving the performance of state-owned banks, consideration should be given to selling a large share of the bank to a foreign strategic partner. In addition to equitization, the more active ownership role by the Ministry of Finance and measures to strengthen the SBV's supervision are important elements of SOCB reform.

49. SOE reform also remains a key policy priority. The authorities are encouraged to implement the new initiatives aimed at reducing the number of strategic sectors in which SOEs will remain under full state ownership and expanding the equitization program to include several large SOEs. In designing the equitization plans, consideration should be given to increase commercial incentives for managers and improve performance. Assessing and assigning performance ratings to SOEs is also a welcome development, but needs to be followed by strict enforcement of timely reporting requirements.

50. Further development of the private sector is key to a successful transition to a more market-oriented economy. The elimination of regulations discriminating against the private sector and measures supporting SMEs have helped the private sector expand rapidly. The full implementation of the amendment to the Land Law would speed up land registration and allocation to private businesses, facilitating private investment. The plans to unify the enterprise law with SOE law and the domestic investment law with the foreign investment law would also promote a level playing field.

51. WTO accession is crucial to maintaining market access and sustaining integration into the international economy and FDI inflows. The staff welcomes the authorities' intention to achieve WTO accession in 2005, which requires significant actions, including putting in place necessary legislation.

52. Vietnam is urged to accept the obligations of Article VIII of the Fund's Articles of Agreement as soon as possible, and eliminate remaining exchange restrictions. Since there is no timetable for removing the restrictions, the staff does not recommend their approval.

53. Vietnam needs to improve transparency as well as reliability and timeliness of data. Improvements are needed particularly in the areas of balance of payments, banking and enterprises, fiscal data, and national income accounts. Passage of the new Statistics Law, which would improve data collection by strengthening inter-agency coordination, is a welcome development, but more timely data provision to the Fund and publication of more economic and financial data are warranted.

54. It is recommended that the next Article IV consultation with Vietnam take place on the standard 12-month cycle. 
Figure 1. Vietnam: Selected Economic Indicators, 1998-2004
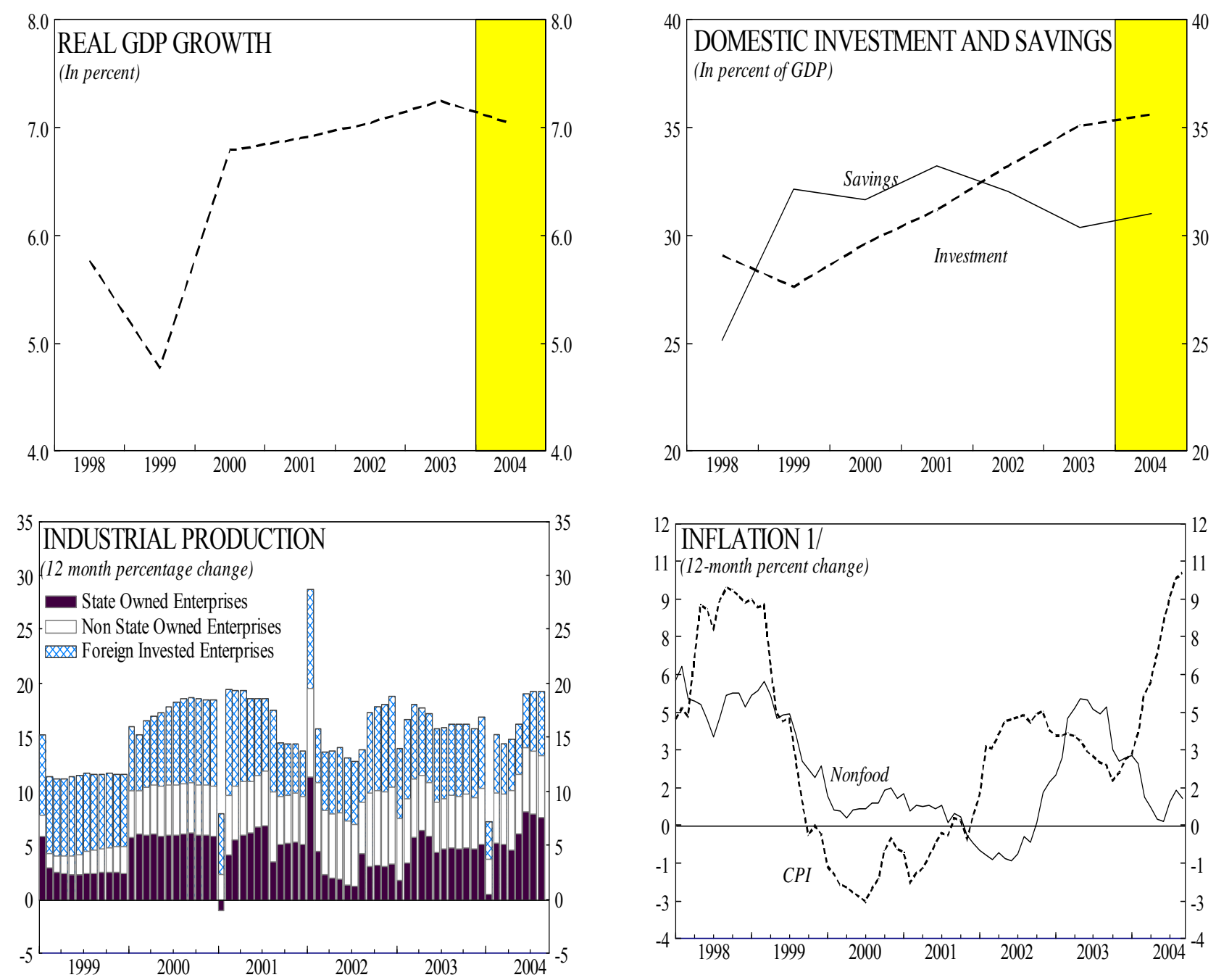

Sources: Data provided by the Vietnamese authorities; and Fund staff estimates. 1 / Based on the June 2000 CPI weights. 
Figure 2 Vietnam: External Sector Background, 1998-2004
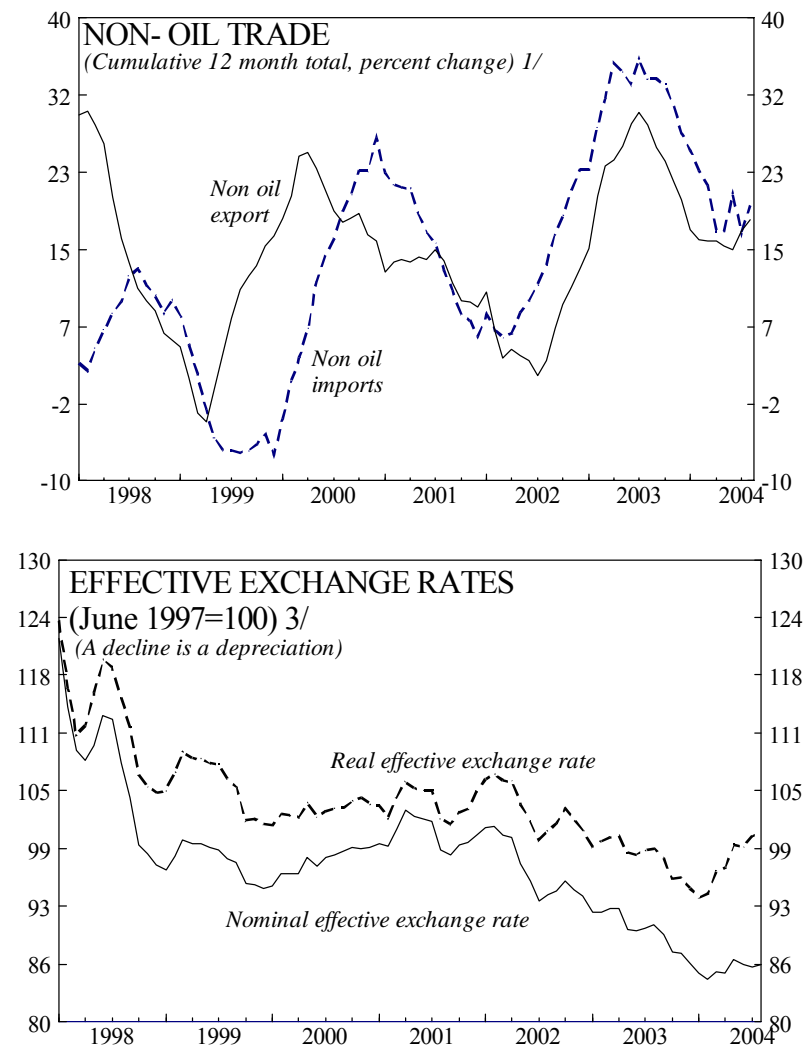
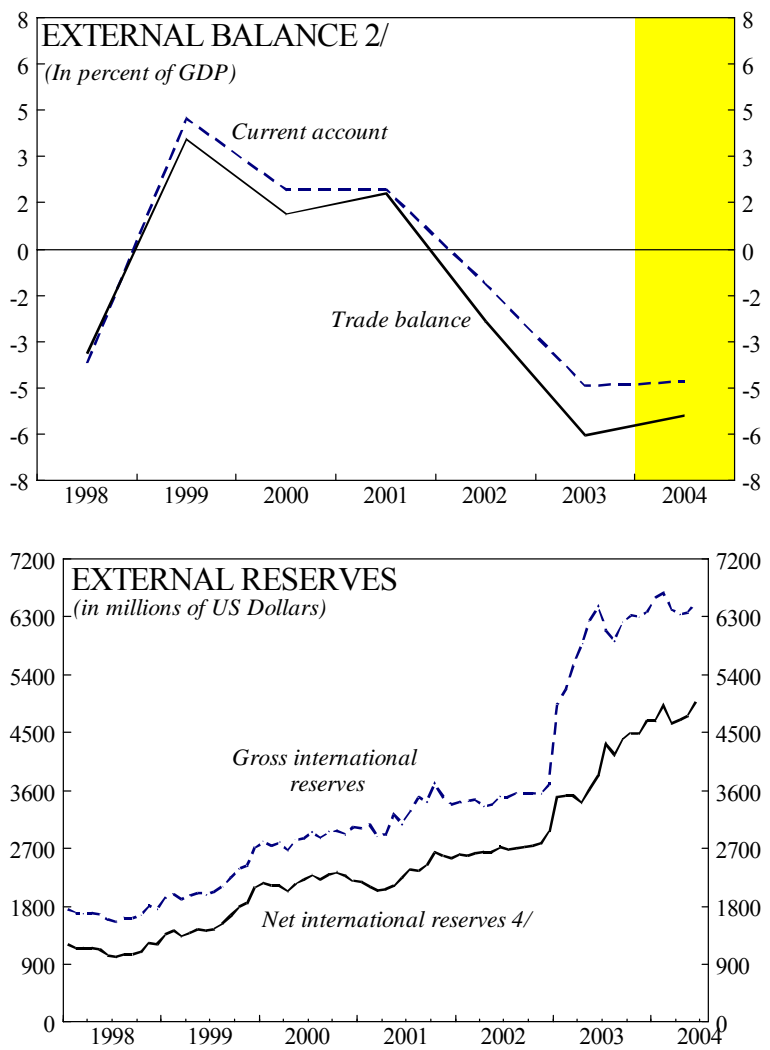

Sources: Data provided by the Vietnamese authorities; and Fund staff estimates.

$1 /$ Monthly data based on c.i.f. imports and exports.

2/ Annual data based on f.o.b. imports and exports.

3/ Estimated for May 2004, and June 2004.

4/ Excludes foreign liabilities and commercial banks' foreign deposits. 
Figure 3. Vietnam: Monetary and Financial Indicators, 1998-2004
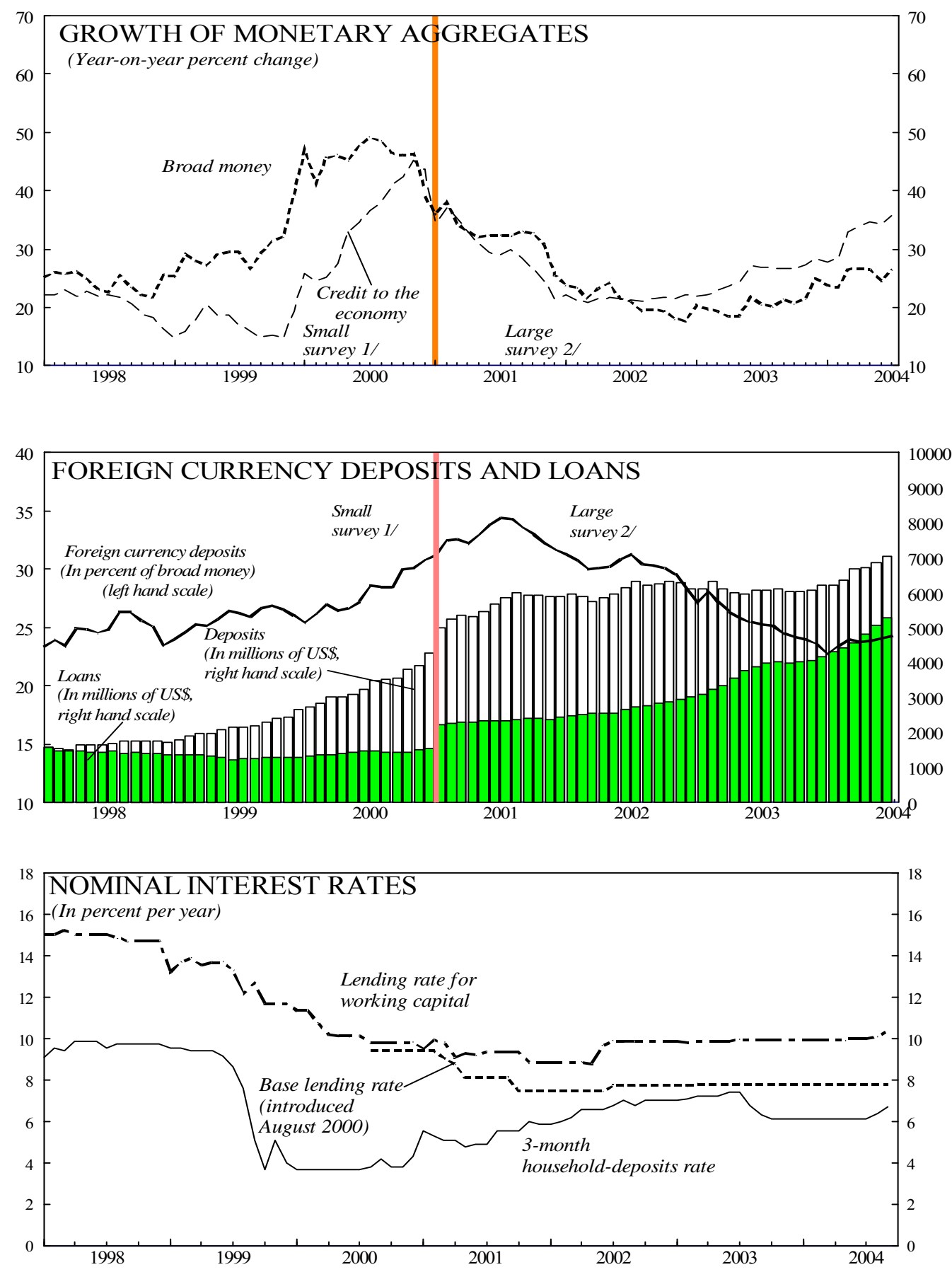

Sources: Data provided by the Vietnamese authorities; and Fund staff estimates.

1/ Monetary survey compromising of State Bank of Vietnam (SBV), four large state owned commercial banks (SOCBs), and 24 non- state banks.

2/ Monetary survey compromising of SBV, four large and two small SOCBs, and 78 non- state banks. 
Figure 4. Vietnam: Fiscal Sector Developments, 1998-2004
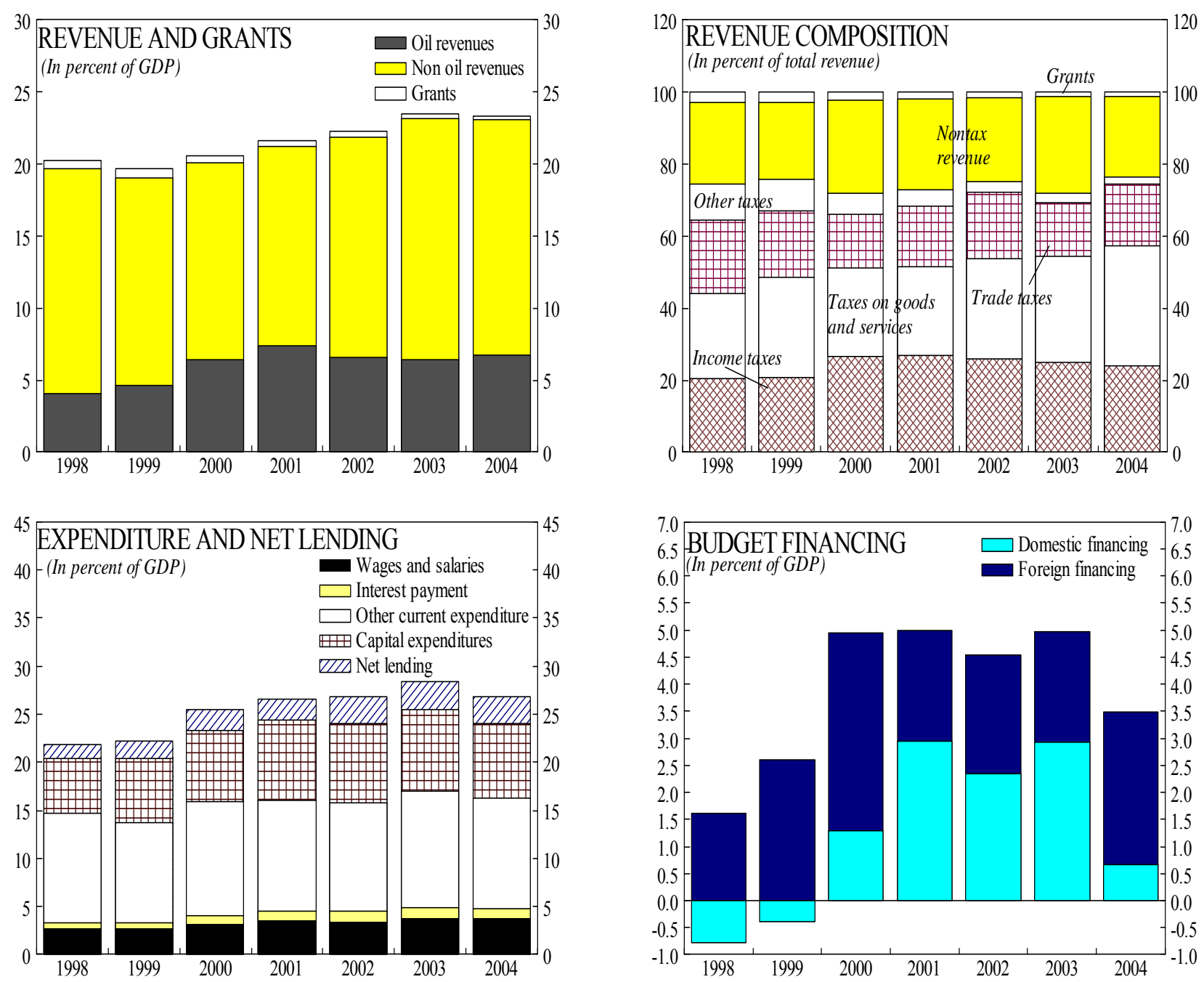

Sources: Data provided by the Vietnamese authorities; and Fund staff estimates. 
Table 1. Vietnam: Social and Demographic Indicators

\begin{tabular}{|c|c|c|c|c|c|c|c|c|c|c|}
\hline \multirow[b]{2}{*}{ Indicator } & \multirow{2}{*}{$\begin{array}{l}\text { Unit of } \\
\text { Measure }\end{array}$} & \multirow[t]{2}{*}{1985} & \multirow{2}{*}{\multicolumn{3}{|c|}{ 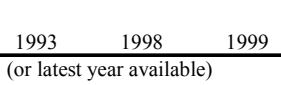 }} & \multirow[t]{2}{*}{2000} & \multirow[t]{2}{*}{2001} & \multirow[t]{2}{*}{2002} & \multicolumn{2}{|c|}{$\begin{array}{l}\text { Same Region/ } \\
\text { Income Group }\end{array}$} \\
\hline & & & & & & & & & $\begin{array}{l}\text { East } \\
\text { Asia }\end{array}$ & $\begin{array}{l}\text { Low- } \\
\text { Income }\end{array}$ \\
\hline \multicolumn{11}{|l|}{ Poverty } \\
\hline Upper poverty line $1 /$ & Thousand dong & $\ldots$ & 1,160 & 1,790 & 1,790 & 1,790 & $\ldots$ & & $\ldots$ & $\ldots$ \\
\hline Percent of population living below & & $\ldots$ & 58 & 37 & 37 & 37 & 32 & 29 & $\ldots$ & $\ldots$ \\
\hline Food poverty line $1 /$ & Thousand dong & $\ldots$ & 750 & 1,287 & 1,287 & 1,287 & 1,287 & 1,287 & $\ldots$ & $\ldots$ \\
\hline Percent of population living below & & $\ldots$ & 25 & 15 & 13 & 13 & 10 & 10 & $\ldots$ & $\ldots$ \\
\hline GDP per capita & U.S. dollars & $\ldots$ & 355 & 360 & 374 & 401 & 413 & 440 & 914 & 432 \\
\hline Access to safe water: total & Percent of population & $\ldots$ & 26.1 & 40.1 & 40.1 & 40.1 & 40.6 & 48.5 & $\ldots$ & $\ldots$ \\
\hline Urban & Percent of population & $\ldots$ & 58.5 & 76.8 & 76.8 & 76.8 & 76.3 & 76.3 & $\ldots$ & $\ldots$ \\
\hline Rural & Percent of population & $\ldots$ & 18.1 & 29.1 & 29.1 & 29.1 & 39.6 & 39.6 & $\ldots$ & $\ldots$ \\
\hline Access to health care $2 /$ & Percent of population & 75.0 & 93.0 & 97.0 & 97.0 & 97.0 & $\ldots$ & $\ldots$ & $\ldots$ & $\ldots$ \\
\hline \multicolumn{11}{|l|}{ Health } \\
\hline \multicolumn{11}{|l|}{ Mortality } \\
\hline Infant mortality & Per thousand live birth & 63 & 36 & 30 & 30 & 18 & 18 & 18 & 34 & 80 \\
\hline Under 5 mortality & Per thousand live birth & 105 & 47 & 40 & 40 & 24 & 24 & 24 & 44 & 121 \\
\hline \multicolumn{11}{|l|}{ Immunization } \\
\hline Measles & Percent of age group & 19.0 & 93.0 & 96.0 & 93.0 & 97.0 & 97.0 & 96.0 & 76.3 & 59.8 \\
\hline DPT & Percent of age group & 42.0 & 91.0 & 95.0 & 93.0 & 96.0 & 98.0 & 75.0 & 76.8 & 61.5 \\
\hline Child malnutrition (under 5) & Percent of age group & 52.0 & 51.0 & 34.0 & 34.0 & 34.0 & 33.8 & 29.5 & 14.8 & $\ldots$ \\
\hline Maternal mortality rate 4/ & Per 100,000 live births & 110 & $\ldots$ & 200 & 200 & 200 & 200 & 165 & $\ldots$ & $\ldots$ \\
\hline Population per physician & Persons & 4,061 & 2,428 & 2,208 & 2,941 & 2,941 & 3,279 & 3,228 & 595 & $\ldots$ \\
\hline Population per nurse & Persons & 1,245 & 723 & 789 & 789 & 789 & 813 & 822 & $\ldots$ & $\ldots$ \\
\hline Population per hospital bed & Persons & 271 & 355 & 379 & 399 & 399 & 409 & 414 & 420 & $\ldots$ \\
\hline \multicolumn{11}{|l|}{ Human resources } \\
\hline Population & Millions & 60 & 69 & 75 & 77 & 78 & 79 & 80 & 1,823 & 2,506 \\
\hline Age dependency ratio & Ratio & 0.82 & 0.74 & 0.66 & 0.64 & 0.62 & 0.60 & 0.58 & 0.50 & 0.70 \\
\hline Urban & Percent of population & 19.6 & 19.8 & 23.1 & 23.6 & 24.2 & 24.7 & 25.1 & 37.3 & 30.8 \\
\hline Population growth rate & Annual percent & 2.2 & 1.7 & 1.6 & 1.5 & 1.4 & 1.4 & 1.3 & 0.9 & 1.8 \\
\hline Urban & Annual percent & 2.4 & 2.8 & 3.7 & 3.5 & 3.8 & 3.7 & 2.8 & 3.3 & 3.0 \\
\hline Life expectancy & Years & 62 & 67 & 68 & 68 & 69 & 69 & 70 & 69 & 59 \\
\hline Female advantage & Years & 3.8 & 4.5 & 4.8 & 4.8 & 4.8 & 4.9 & 4.9 & 3.5 & 2.1 \\
\hline Total fertility rate & Births per woman & 4.6 & 3.3 & 2.4 & 2.3 & 1.9 & 2.2 & 1.9 & 2.1 & 3.5 \\
\hline Labor force (15-64) & Millions & 29 & 36 & 39 & 40 & 40 & 41 & 42 & 1,038 & 1,138 \\
\hline Female & Percent of labor force & 48.9 & 49.5 & 49.1 & 49.0 & 48.9 & 48.8 & 48.7 & 44.5 & 37.9 \\
\hline \multicolumn{11}{|l|}{ Natural resources } \\
\hline Area & Thousands sq. km. & 325 & 325 & 325 & 325 & 325 & 325 & 325 & 16,301 & 33,031 \\
\hline Density & Persons per sq. km. & 184 & 213 & 232 & 235 & 239 & 242 & 245 & 115 & 76 \\
\hline Agricultural lands & Percent of land area & 21.0 & 24.0 & 26.2 & 26.2 & 26.2 & 26.2 & 26.2 & $\ldots$ & $\ldots$ \\
\hline Agricultural land under irrigation & Percent & 28.0 & 28.0 & 30.2 & 30.2 & 30.2 & 30.2 & 30.2 & $\ldots$ & $\ldots$ \\
\hline Forests and woodland & Thousand sq. km. & 97 & 83 & $\ldots$ & 109 & 109 & 109 & 98 & $\ldots$ & $\ldots$ \\
\hline Energy consumption per capita & $\mathrm{Kg}$. of oil equivalent & 368 & 383 & 448 & 454 & 471 & 495 & $\ldots$ & 871 & 569 \\
\hline \multicolumn{11}{|l|}{ Income } \\
\hline Share of top 20 percent of households & Percent of income & $\ldots$ & 42.0 & 43.3 & 43.3 & 43.3 & 45.9 & 46.0 & $\ldots$ & $\ldots$ \\
\hline Share of bottom 40 percent of households & Percent of income & $\ldots$ & 20.7 & 20.1 & 20.1 & 20.1 & 19.0 & 19.0 & $\ldots$ & $\ldots$ \\
\hline Share of bottom 20 percent of households & Percent of income & $\ldots$ & 8.0 & 8.2 & 8.2 & 8.2 & 7.8 & 7.8 & $\ldots$ & $\ldots$ \\
\hline \multicolumn{11}{|l|}{ Education } \\
\hline Net enrollment ratios & & & & & & & & & & \\
\hline Primary & Percent of gross & 103.0 & 111.0 & 109.0 & 108.0 & 106.0 & 103.0 & $\ldots$ & 105.7 & 91.8 \\
\hline Male 3/ & Percent of gross & 106.0 & 114.0 & 114.0 & 111.0 & 109.0 & 107.0 & $\ldots$ & 105.3 & 103.0 \\
\hline Female 3/ & Percent of gross & 100.0 & 108.0 & 105.0 & 104.0 & 102.0 & 100.0 & $\ldots$ & 106.1 & 87.5 \\
\hline Pupil-teacher ratio: primary & Pupils per teacher & 34 & 35 & 30 & 30 & 28 & 26 & 24 & & \\
\hline Secondary & Percent of Gross & 42.7 & 35.5 & 61.9 & 65.0 & 67.1 & 69.7 & & 60.8 & 44.5 \\
\hline Illiteracy & Percent of population age $15+$ & 10.8 & 9.0 & 7.9 & 7.7 & 7.5 & 7.3 & $\ldots$ & 13.2 & 37.0 \\
\hline Female & Percent of female age $15+$ & 14.9 & 11.8 & 10.0 & 9.7 & 9.3 & 9.1 & $\ldots$ & 19.2 & 46.1 \\
\hline
\end{tabular}

Sources: Vietnam: Statistical Yearbook (various years), and General Statistical Office, Vietnam Living Standards Survey 1997-1998; World Bank: Vietnam Development Report 2000: Attacking Poverty, and Vietnam Development Report 2001: Entering the $21{ }^{\text {st }}$ Century, Vietnam Development Report 2004: Poverty; Vietnam Population Committee: Demographic and Health Survey 2002; and World Development Indicators; and staff estimates.

1/ The upper poverty line is constituted by the cost of a representative food bundle yielding 2,100 calories per day, plus a representative nonfood component. The lower poverty line represents the approximate cost of this food bundle only.

2/ For 1993 and 1998, rural population.

3/ For 1993 and 1998, net enrollment ratios. 
Table 2. Vietnam: Selected Economic Indicators, 2000-05

Nominal GDP (2003): US\$39.0 billion Population (2003): 80.9 million
GDP per capita (2003): US\$483 Fund quota: SDR 329.1 million

\begin{tabular}{|c|c|c|c|c|c|c|c|}
\hline & \multirow[t]{2}{*}{2000} & \multirow[t]{2}{*}{2001} & \multirow[t]{2}{*}{2002} & \multirow{2}{*}{$\begin{array}{r}2003 \\
\text { Est. }\end{array}$} & \multicolumn{2}{|l|}{2004} & \multirow{2}{*}{$\begin{array}{l}2005 \\
\text { Proj. }\end{array}$} \\
\hline & & & & & August 1/ & Proj. & \\
\hline Real GDP (annual percentage change) & 6.8 & 6.9 & 7.1 & 7.3 & $\ldots$ & $7-71 / 2$ & $7-71 / 2$ \\
\hline Industrial output & 18.4 & 13.7 & 18.8 & 16.9 & 19.2 & $\ldots$ & $\ldots$ \\
\hline \multicolumn{8}{|l|}{ Inflation (annual percentage change) } \\
\hline Period average & -1.6 & -0.4 & 4.0 & 3.2 & $6.92 /$ & $7-8$ & $5-6$ \\
\hline End of period & -0.5 & 0.7 & 4.0 & 2.9 & $10.12 /$ & $91 / 2$ & $4-5$ \\
\hline \multicolumn{8}{|l|}{ General government budget } \\
\hline Total revenue and grants & 20.5 & 21.6 & 22.2 & 23.4 & $20.53 /$ & 23.3 & 23.4 \\
\hline of which: oil revenue & 6.5 & 7.4 & 6.6 & 6.5 & $\ldots$ & 6.7 & 6.8 \\
\hline Total Expenditure and net lending & 25.5 & 26.6 & 26.8 & 28.4 & $21.63 /$ & 26.8 & 28.1 \\
\hline Current expenditure & 15.9 & 16.0 & 15.8 & 17.0 & $14.93 /$ & 16.3 & 17.6 \\
\hline Capital expenditure & 7.4 & 8.4 & 8.2 & 8.4 & $6.73 /$ & 7.8 & 8.2 \\
\hline Net lending 4/ & 2.2 & 2.2 & 2.7 & 2.9 & $\ldots$ & 2.7 & 2.3 \\
\hline Fiscal balance & -5.0 & -5.0 & -4.5 & -5.0 & $\ldots$ & -3.5 & -4.7 \\
\hline (Excluding net lending) & -2.7 & -2.8 & -1.9 & -2.0 & $\ldots$ & -0.8 & -2.4 \\
\hline \multicolumn{8}{|l|}{ Money and credit (annual percentage change, end of period) } \\
\hline Broad money & 39.0 & 25.5 & 17.6 & 24.9 & $26.45 /$ & $\ldots$ & $\ldots$ \\
\hline Credit to the economy & 38.1 & 21.4 & 22.2 & 28.4 & $35.75 /$ & $\ldots$ & $\ldots$ \\
\hline \multicolumn{8}{|l|}{ Interest rates (in percent, end of period) } \\
\hline Three-month deposits (households) & 4.3 & 5.9 & 7.0 & 6.3 & $6.76 /$ & $\ldots$ & $\ldots$ \\
\hline Short-term lending (less than one year) & 9.8 & 8.8 & 9.9 & 10.0 & $10.36 /$ & $\ldots$ & $\ldots$ \\
\hline \multicolumn{8}{|l|}{ Current account balance (including official transfers) } \\
\hline (in millions of U.S. dollars) & 642 & 670 & -421 & $-1,844$ & $\ldots$ & $-1,942$ & $-2,145$ \\
\hline (in percent of GDP) & 2.1 & 2.1 & -1.2 & -4.7 & $\ldots$ & -4.4 & -4.5 \\
\hline Exports f.o.b (annual percentage change, U.S. dollar terms) & 25.2 & 4.0 & 11.2 & 19.6 & $26.17 /$ & 22.9 & 12.3 \\
\hline Imports f.o.b. (annual percentage change, U.S. dollar terms) & 34.5 & 2.3 & 22.1 & 27.9 & $22.87 / 8 /$ & 20.1 & 12.3 \\
\hline \multicolumn{8}{|l|}{ Foreign exchange reserves (in millions of U.S. dollars, end of period) } \\
\hline Gross official reserves, including gold & 3,030 & 3,387 & 3,692 & 5,620 & $5,7665 /$ & 6,004 & 6,237 \\
\hline (in weeks of next year's imports of goods and nonfactor services) & 8.9 & 8.3 & 7.3 & 9.3 & $9.65 /$ & 8.9 & 8.0 \\
\hline Net international reserves, including gold & 2,191 & 2,555 & 2,956 & 4,683 & $4,7365 /$ & $\ldots$ & $\ldots$ \\
\hline External debt (in percent of GDP) $9 /$ & 38.6 & 37.9 & 34.9 & 34.1 & $\ldots$ & 34.0 & 34.9 \\
\hline Debt service due (in percent of exports of goods and nonfactor services) & 10.5 & 10.6 & 8.6 & 7.9 & $\ldots$ & 6.5 & 6.0 \\
\hline \multicolumn{8}{|l|}{ Exchange rate (dong per U.S. dollar) } \\
\hline Period average & 14,170 & 14,806 & 15,272 & 15,514 & 15,767 & $\ldots$ & $\ldots$ \\
\hline End of period & 14,514 & 15,084 & 15,404 & 15,646 & 15,764 & $\ldots$ & $\ldots$ \\
\hline \multicolumn{8}{|l|}{ Real effective exchange rate (annual percentage change) } \\
\hline Period average & -2.8 & 0.9 & -0.6 & -5.0 & -1.7 & $\ldots$ & $\ldots$ \\
\hline End of period & 2.2 & 1.3 & -4.1 & -6.2 & $6.310 /$ & $\ldots$ & $\ldots$ \\
\hline \multicolumn{8}{|l|}{ Memorandum items: } \\
\hline GDP (in trillions of dong at current market prices) & 441.6 & 481.3 & 535.8 & 605.6 & $\ldots$ & 716.8 & 807.9 \\
\hline Per capita GDP (in U.S. dollars) & 401 & 413 & 440 & 483 & $\ldots$ & 537 & 568 \\
\hline
\end{tabular}

Sources: Data provided by the authorities; and Fund staff estimates and projections.

1/ Data as of August 2004, unless otherwise indicated.

2/ September 2004

3/ June 2004.

4/ Includes DAF operations. The authorities record ODA received for onlending; repayments are included under amortization.

5/ July 2004.

6/ September 2004

7/ Growth rates of cumulative exports and imports for the year so far, compared with the same period last year.

8/ For monthly data, rate of growth based on imports c.i.f.

9/ Includes the loan component of foreign direct investment and other private sector borrowing and short-term debt.

10/ Compared to end-2003. 
Table 3. Vietnam: Balance of Payments, 2000-05

(In millions of U.S. dollars, unless otherwise indicated)

\begin{tabular}{|c|c|c|c|c|c|c|}
\hline & 2000 & 2001 & 2002 & 2003 & 2004 & 2005 \\
\hline & & & & Est. & \multicolumn{2}{|c|}{ Proj. } \\
\hline Current account balance & 642 & 670 & -421 & $-1,844$ & $-1,942$ & $-2,145$ \\
\hline Excluding official transfers & 506 & 520 & -552 & $-1,983$ & $-2,081$ & $-2,284$ \\
\hline Trade balance & 378 & 627 & -876 & $-2,510$ & $-2,455$ & $-2,757$ \\
\hline Exports, f.o.b. & 14,449 & 15,027 & 16,706 & 19,986 & 24,562 & 27,582 \\
\hline of which: oil & 3,503 & 3,126 & 3,270 & 3,821 & 5,487 & 5,925 \\
\hline Imports, f.o.b. & 14,071 & 14,400 & 17,582 & 22,495 & 27,017 & 30,339 \\
\hline of which: oil & 2,016 & 1,828 & 2,017 & 2,410 & 3,509 & 4,246 \\
\hline Non-factor services (net) & -615 & -572 & -648 & -778 & -886 & -912 \\
\hline Receipts & 2,695 & 2,810 & 2,948 & 3,272 & 3,508 & 4,025 \\
\hline Payments & 3,310 & 3,382 & 3,596 & 4,050 & 4,394 & 4,937 \\
\hline Investment income (net) & -597 & -635 & -794 & -796 & -940 & -915 \\
\hline Receipts & 185 & 160 & 167 & 125 & 165 & 288 \\
\hline Payments & 782 & 795 & 961 & 921 & 1,105 & 1,203 \\
\hline Interest payment & 529 & 345 & 293 & 290 & 393 & 419 \\
\hline Dividends on FDI & $\ldots$ & $\ldots$ & 668 & 631 & 712 & 784 \\
\hline Transfers (net) & 1,476 & 1,250 & 1,898 & 2,239 & 2,339 & 2,439 \\
\hline Private & 1,340 & 1,100 & 1,767 & 2,100 & 2,200 & 2,300 \\
\hline Official & 136 & 150 & 131 & 139 & 139 & 139 \\
\hline Capital account balance & -526 & -476 & 885 & 3,992 & 2,313 & 2,378 \\
\hline Gross foreign direct investment (FDI) inflows & 1,101 & 1,252 & 2,045 & 1,829 & 1,155 & 1,400 \\
\hline Equity & 977 & 1,067 & 1,904 & 1,228 & 755 & 1,000 \\
\hline Loan disbursements & 124 & 185 & 141 & 600 & 400 & 400 \\
\hline FDI loan repayments & 601 & 819 & 414 & 590 & 400 & 524 \\
\hline Medium and long-term loans (net) & 729 & 623 & 526 & 1,047 & 1,454 & 1,532 \\
\hline Disbursements & 1,411 & 988 & 1,102 & 1,540 & 1,981 & 2,013 \\
\hline ODA loans & 1,361 & 958 & 1,073 & 1,258 & 1,419 & 1,500 \\
\hline Commercial loans & 50 & 30 & 29 & 283 & 562 & 513 \\
\hline Amortization 1/ & 682 & 365 & 576 & 493 & 527 & 481 \\
\hline Short-term capital (net) $2 /$ & $-1,755$ & $-1,532$ & $-1,273$ & 1,706 & 104 & -30 \\
\hline Overall balance & 115 & 194 & 464 & 2,148 & 372 & 233 \\
\hline Financing & -115 & -194 & -464 & -2148 & -384 & -233 \\
\hline Change in reserves (- indicates increase) & -115 & -194 & -464 & $-2,148$ & -384 & -233 \\
\hline \multicolumn{7}{|l|}{ Memorandum items: } \\
\hline Gross official reserves & 3,030 & 3,387 & 3,692 & 5,620 & 6,004 & 6,237 \\
\hline In weeks of next year's imports & 8.9 & 8.3 & 7.3 & 9.3 & 8.9 & 8.0 \\
\hline Current account deficit (in percent of GDP) & 2.1 & 2.1 & -1.2 & -4.7 & -4.4 & -4.5 \\
\hline Non-oil current account deficit (in percent of GDP) & -2.7 & -1.9 & -4.8 & -8.3 & -8.9 & -8.1 \\
\hline Export value growth (in percent) & 25.2 & 4.0 & 11.2 & 19.6 & 22.9 & 12.3 \\
\hline Import value growth (in percent) & 34.5 & 2.3 & 22.1 & 27.9 & 20.1 & 12.3 \\
\hline External debt (in percent of GDP) & 38.6 & 37.9 & 34.9 & 34.1 & 34.0 & 34.9 \\
\hline Debt service (in percent of exports of exports of goods & 10.5 & 10.6 & 8.6 & 7.9 & 6.5 & 6.0 \\
\hline
\end{tabular}

Sources: Data provided by the Vietnamese authorities; and staff estimates and projections.

1/ Including two debt buyback operations carried out in 2002 and 2003, respectively. 
Table 4. Vietnam: Monetary Survey, 2000-04 1/

\begin{tabular}{|c|c|c|c|c|c|c|c|c|c|c|}
\hline & \multirow[t]{2}{*}{2000} & \multirow[t]{2}{*}{2001} & \multirow[t]{2}{*}{2002} & \multicolumn{4}{|c|}{2003} & \multicolumn{3}{|c|}{2004} \\
\hline & & & & Mar. & June & Sept. & $\overline{\text { Dec. }}$ & Mar. & June & July \\
\hline & \multicolumn{10}{|c|}{ (In trillions of Dong) } \\
\hline Net foreign assets & 95.7 & 117.6 & 117.4 & 127.4 & 125.6 & 129.9 & 131.4 & 133.6 & 130.5 & 134.3 \\
\hline Foreign assets & 112.7 & 135.9 & 135.9 & 144.4 & 143.7 & 147.8 & 150.5 & 153.2 & 152.1 & 156.7 \\
\hline Foreign liabilities & -17.0 & -18.3 & -18.4 & -17.0 & -18.1 & -17.9 & -19.1 & -19.6 & -21.7 & -22.4 \\
\hline Net domestic assets & 127.2 & 162.2 & 211.7 & 218.3 & 242.9 & 252.3 & 279.8 & 303.8 & 328.4 & 334.7 \\
\hline Domestic credit & 155.2 & 191.2 & 239.9 & 246.5 & 274.8 & 290.4 & 316.9 & 341.5 & 372.4 & 379.8 \\
\hline Net claims on government 2 / & -0.5 & 2.1 & 8.8 & 2.6 & 9.0 & 12.7 & 20.1 & 17.0 & 15.6 & 13.8 \\
\hline Credit to the economy 3 / & 155.7 & 189.1 & 231.1 & 243.9 & 265.8 & 277.6 & 296.7 & 324.5 & 356.8 & 366.0 \\
\hline Of which in foreign currency & 32.3 & 36.5 & 46.2 & 51.6 & 60.1 & 61.7 & 65.2 & 71.9 & 83.0 & \\
\hline Claims on state enterprises 3/ 4/ & 69.9 & 79.7 & 89.5 & 92.3 & 97.8 & 101.2 & 105.4 & 115.8 & 127.5 & $\ldots$ \\
\hline Claims on other sectors $3 / 4$ / & 85.8 & 109.4 & 141.6 & 151.6 & 168.0 & 176.4 & 191.3 & 208.6 & 229.3 & \\
\hline Other items, net & -28.0 & -29.0 & -28.2 & -28.3 & -31.9 & -38.1 & -37.0 & -37.7 & -44.0 & -45.0 \\
\hline Total liquidity (M2) & 222.9 & 279.8 & 329.1 & 345.7 & 368.5 & 382.2 & 411.2 & 437.4 & 458.9 & 469.1 \\
\hline Of which: total deposits & 170.7 & 213.5 & 254.9 & 266.8 & 288.5 & 301.7 & 320.6 & 341.7 & 363.8 & 373.6 \\
\hline Dong liquidity & 152.5 & 191.1 & 235.5 & 251.6 & 274.7 & 288.6 & 314.1 & 332.5 & 348.1 & 355.1 \\
\hline Currency outside banks & 52.2 & 66.3 & 74.3 & 78.9 & 79.9 & 80.5 & 90.6 & 95.7 & 95.0 & 95.5 \\
\hline Deposits & 100.3 & 124.8 & 161.3 & 172.7 & 194.7 & 208.1 & 223.6 & 236.9 & 253.1 & 259.6 \\
\hline Foreign currency deposits & 70.4 & 88.7 & 93.6 & 94.1 & 93.8 & 93.6 & 97.1 & 104.9 & 110.7 & 114.0 \\
\hline \multirow[t]{2}{*}{ (in millions of U.S. dollars) } & 4,854 & 5,884 & 6,093 & 6,106 & 6,066 & 6,032 & 6,220 & 6,670 & 7,042 & 7,235 \\
\hline & \multicolumn{10}{|c|}{ (Annual percentage change, unless otherwise indicated) } \\
\hline Net foreign assets & 56.4 & 22.9 & -0.2 & 9.1 & 4.0 & 8.0 & 11.9 & 4.8 & 3.9 & 8.5 \\
\hline Net domestic assets & 28.2 & 27.5 & 30.6 & 26.1 & 33.5 & 29.5 & 32.2 & 39.2 & 35.2 & 35.4 \\
\hline Domestic credit & 34.2 & 23.2 & 25.5 & 22.4 & 30.0 & 29.3 & 32.1 & 38.5 & 35.5 & 34.9 \\
\hline Credit to the economy 3 / & 38.1 & 21.4 & 22.2 & 22.9 & 27.1 & 26.6 & 28.4 & 33.0 & 34.2 & 35.7 \\
\hline Of which in foreign currency & 11.8 & 13.1 & 26.6 & 33.7 & 48.1 & 43.0 & 41.0 & 39.3 & 38.1 & \\
\hline Claims on state enterprises 3 / & 28.7 & 14.1 & 12.2 & 13.0 & 16.3 & 16.4 & 17.8 & 25.5 & 30.4 & \\
\hline Claims on other sectors $3 /$ & 46.9 & 27.5 & 29.5 & 29.8 & 34.3 & 33.2 & 35.1 & 37.6 & 36.5 & $\ldots$ \\
\hline Total liquidity (M2) & 39.0 & 25.5 & 17.6 & 19.3 & 21.7 & 21.3 & 24.9 & 26.5 & 24.5 & 26.4 \\
\hline Of which: total deposits & 43.3 & 25.1 & 19.4 & 24.0 & 24.2 & 22.8 & 25.8 & 28.1 & 26.1 & 28.6 \\
\hline Dong liquidity & 30.8 & 25.3 & 23.2 & 24.1 & 31.3 & 31.6 & 33.4 & 32.2 & 26.8 & 28.1 \\
\hline Currency outside banks & 26.6 & 27.0 & 12.0 & 5.6 & 13.6 & 16.2 & 22.0 & 21.3 & 18.9 & 18.5 \\
\hline Deposits & 33.2 & 24.4 & 29.2 & 34.9 & 40.2 & 38.7 & 38.6 & 37.2 & 30.0 & 32.0 \\
\hline \multirow[t]{2}{*}{ Foreign currency deposits } & 60.5 & 26.0 & 5.6 & 8.0 & 0.4 & -2.2 & 3.7 & 11.4 & 18.0 & 21.5 \\
\hline & \multicolumn{10}{|c|}{ (In percent, unless otherwise indicated ) } \\
\hline Memorandum items: & & & & & & & & & & \\
\hline Velocity 4/ & 1.9 & 1.6 & 1.6 & 1.6 & 1.5 & 1.5 & 1.4 & 1.3 & 1.2 & 1.2 \\
\hline Dong velocity $4 /$ & 2.8 & 2.5 & 2.2 & 2.3 & 2.1 & 2.0 & 1.8 & 1.7 & 1.6 & 1.6 \\
\hline Money multiplier 5/ & 3.1 & 3.3 & 3.4 & 3.1 & 2.9 & 3.3 & 3.4 & 3.7 & 3.7 & 3.8 \\
\hline Currency/broad money & 23.4 & 23.7 & 22.6 & 22.8 & 21.7 & 21.1 & 22.0 & 21.9 & 20.7 & 20.4 \\
\hline Currency/dong deposits & 52.1 & 53.1 & 46.1 & 45.7 & 41.1 & 38.7 & 40.5 & 40.4 & 37.5 & 36.8 \\
\hline Foreign currency deposits/total deposits & 41.2 & 41.5 & 36.7 & 35.3 & 32.5 & 31.0 & 31.0 & 30.7 & 30.4 & 30.5 \\
\hline \multirow[t]{2}{*}{ Foreign currency loans/total loans } & 20.7 & 19.3 & 20.0 & 21.1 & 22.6 & 22.2 & 22.0 & 22.2 & 23.3 & $\ldots$ \\
\hline & \multicolumn{10}{|c|}{ (In millions of U.S. dollar, unless otherwise indicated) } \\
\hline Gross official international reserves (adjusted) 6/ & 3,030 & 3,387 & 3,692 & 4,814 & 5,616 & 5,317 & 5,620 & 5,563 & 5,886 & 5,766 \\
\hline Net official international reserves (adjusted) 6/7/ & 2,191 & 2,555 & 2,956 & 3,516 & 3,826 & 4,397 & 4,683 & 4,646 & 4,983 & 4,858 \\
\hline Net foreign assets of the banking system & 6,599 & 7,805 & 7,640 & 8,266 & 8,120 & 8,372 & 8,419 & 8,496 & 8,298 & 8,529 \\
\hline
\end{tabular}

Sources: State Bank of Vietnam; and Fund staff estimates.

1/ Data comprise the State Bank of Vietnam (SBV), six state-owned commercial banks, and 83 non-state owned banks.

2/ Fund staff projections exclude capital cost of banking reform and the possible issuance of international bonds by the government.

3/ Fund staff projections exclude the possible transfer in collateralized nonperforming loans of commercial banks to an AMC.

4/ Velocity is measured as the ratio of GDP to end-of-period total liquidity (M2) or dong liquidity respectively

5/ Money multiplier is measured as the ratio of total liquidity (M2) to reserve money.

6/ Excludes foreign currency counterpart of swap operations, government foreign currency deposits at the SBV,

and foreign currency transactions related to the possible issuance of international bonds by the government.

7/ Excludes foreign currency deposits of DMBs at the SBV. 
Table 5. Vietnam: Summary of General Government Budgetary Operations, 2000-05

\begin{tabular}{|c|c|c|c|c|c|c|c|}
\hline & \multirow[t]{2}{*}{2000} & \multirow[t]{2}{*}{2001} & \multirow[t]{2}{*}{2002} & \multirow[t]{2}{*}{2003} & \multicolumn{2}{|c|}{2004} & \multirow{2}{*}{$\frac{2005}{\text { Proj }}$} \\
\hline & & & & & Budget & Proj. & \\
\hline & \multicolumn{7}{|c|}{ (in percent of GDP) } \\
\hline Total Revenue and grants & 20.5 & 21.6 & 22.2 & 23.4 & 20.8 & 23.3 & 23.4 \\
\hline Oil revenues & 6.5 & 7.4 & 6.6 & 6.5 & $\ldots$ & 6.7 & 6.8 \\
\hline Nonoil revenue & 13.6 & 13.8 & 15.2 & 16.7 & $\ldots$ & 16.3 & 16.3 \\
\hline Tax revenue & 11.5 & 11.6 & 12.9 & 13.9 & $\ldots$ & 12.8 & 12.8 \\
\hline Nontax revenue & 2.1 & 2.2 & 2.4 & 2.8 & $\ldots$ & 3.5 & 3.5 \\
\hline Grants & 0.5 & 0.4 & 0.4 & 0.3 & 0.3 & 0.3 & 0.3 \\
\hline Total Expenditure and net lending & 25.5 & 26.6 & 26.8 & 28.4 & 25.9 & 26.8 & 28.1 \\
\hline Current Expenditure & 15.9 & 16.0 & 15.8 & 17.0 & 15.5 & 16.3 & 17.6 \\
\hline Wages and salaries & 3.3 & 3.6 & 3.4 & 3.8 & $\ldots$ & 3.8 & 4.2 \\
\hline Interest payments & 0.8 & 0.9 & 1.1 & 1.1 & 0.9 & 0.9 & 1.0 \\
\hline Other current expenditure & 11.8 & 11.5 & 11.3 & 12.2 & $\ldots$ & 11.5 & 12.5 \\
\hline Capital Expenditure & 7.4 & 8.4 & 8.2 & 8.4 & 7.5 & 7.8 & 8.2 \\
\hline Net lending $1 /$ & 2.2 & 2.2 & 2.7 & 2.9 & 2.9 & 2.7 & 2.3 \\
\hline ODA financed & 2.2 & 1.0 & 1.2 & 1.3 & 1.6 & 1.6 & 1.2 \\
\hline domestically financed & 0.0 & 1.2 & 1.5 & 1.7 & 1.3 & 1.1 & 1.1 \\
\hline Fiscal Balance & -5.0 & -5.0 & -4.5 & -5.0 & -5.1 & -3.5 & -4.7 \\
\hline (Excluding net lending) & -2.7 & -2.8 & -1.9 & -2.0 & -2.2 & -0.8 & -2.4 \\
\hline Financing & 5.0 & 5.0 & 4.5 & 5.0 & 5.1 & 3.5 & 4.7 \\
\hline Domestic (net) & 1.3 & 2.9 & 2.3 & 2.9 & 3.1 & 0.7 & 2.0 \\
\hline Banking System & -0.8 & 0.5 & 0.4 & 1.9 & $\ldots$ & $\ldots$ & $\ldots$ \\
\hline Nonbank public & 2.1 & 2.4 & 2.0 & 1.1 & $\ldots$ & $\ldots$ & $\ldots$ \\
\hline Foreign (net) & 3.7 & 2.0 & 2.2 & 2.1 & 2.0 & 2.8 & 2.7 \\
\hline Borrowing & 4.2 & 2.5 & 2.6 & 2.5 & 2.7 & 3.2 & 3.2 \\
\hline Amortization & 0.5 & 0.4 & 0.4 & 0.5 & 0.6 & 0.4 & 0.4 \\
\hline \multicolumn{8}{|l|}{ Memorandum Items } \\
\hline Reform costs $2 /$ & 0.0 & 0.3 & 0.7 & 14.7 & $\ldots$ & 4.8 & 2.7 \\
\hline Public debt stock $3 /$ & $\ldots$ & $\ldots$ & 33.9 & 50.1 & $\ldots$ & 51.6 & 54.3 \\
\hline Domestic & $\ldots$ & $\ldots$ & 9.2 & 25.8 & $\ldots$ & 27.3 & 28.9 \\
\hline Foreign & $\ldots$ & $\ldots$ & 24.7 & 24.3 & $\ldots$ & 24.3 & 25.4 \\
\hline Non-oil deficit (as a share of nonoil GDP) & -14.3 & -15.2 & -14.4 & -14.4 & $\ldots$ & -13.5 & -14.3 \\
\hline Expenditure managed by units $4 /$ & 1.4 & 1.8 & 1.6 & 2.5 & 2.7 & 2.7 & $\ldots$ \\
\hline Total poverty reducing expenditures $5 /$ & 5.3 & 5.7 & 5.9 & 6.3 & $\ldots$ & 6.2 & $\ldots$ \\
\hline Costs of social safety nets & 0.0 & 0.0 & 0.0 & 0.1 & $\ldots$ & 0.2 & $\ldots$ \\
\hline Nonoil GDP (trillions of dong) & 421 & 462 & 517 & 584 & 686 & 686 & 784 \\
\hline Nominal GDP (trillions of dong) & 442 & 481 & 536 & 606 & 717 & 717 & 808 \\
\hline
\end{tabular}

Sources: Ministry of Finance; and Fund staff estimates

1/ Includes DAF operations. The authorities record ODA received for onlending; repayments are included under amortization. 2/ From 2003 onward, contingent liabilities of the banking system are taken into account.

3 / Including DAF debt and contingent liabilities.

4/ Self-financed expenditures undertaken by government administrative units, which are excluded from the above budget present 5/ Staff estimate based on (i) current expenditure on education, training, health, and family planning and (ii) capital expenditure training, health, and poverty-related projects in the agriculture, transportation, electricity, and water sectors. 
Table 6. Vietnam: Medium-Term Scenario, 2000-09

\begin{tabular}{|c|c|c|c|c|c|c|c|c|c|c|}
\hline & 2000 & 2001 & 2002 & 2003 & 2004 & 2005 & 2006 & 2007 & 2008 & 2009 \\
\hline & & & & & \multicolumn{6}{|c|}{ Projection } \\
\hline & \multicolumn{10}{|c|}{ (Percentage change) } \\
\hline Real GDP (annual percentage change) & 6.8 & 6.9 & 7.1 & 7.3 & $7-71 / 2$ & $7-71 / 2$ & 7.0 & 7.0 & 7.0 & 7.0 \\
\hline Consumer prices (annual average) & -1.6 & -0.4 & 4.0 & 3.2 & $7-8$ & $5-6$ & 4.0 & 3.5 & 3.5 & 3.0 \\
\hline & \multicolumn{10}{|c|}{ (In percent of GDP) } \\
\hline Saving-investment balance & 2.1 & 2.1 & -1.2 & -4.7 & -4.4 & -4.5 & -3.5 & -2.4 & -1.5 & -1.1 \\
\hline Gross national saving & 31.7 & 33.2 & 32.0 & 30.4 & 31.1 & 30.1 & 31.0 & 31.3 & 31.5 & 31.1 \\
\hline Gross investment & 29.6 & 31.2 & 33.2 & 35.1 & 35.5 & 34.6 & 34.5 & 33.7 & 33.0 & 32.2 \\
\hline ICOR & 4.1 & 4.2 & 4.4 & 4.5 & 4.6 & 4.6 & 4.6 & 4.4 & 4.3 & 4.2 \\
\hline General government budget & -5.0 & -5.0 & -4.5 & -5.0 & -3.5 & -4.7 & -4.7 & -4.7 & -4.7 & -4.7 \\
\hline (excluding net lending) & -2.7 & -2.8 & -1.9 & -2.0 & -0.8 & -2.4 & -2.3 & -2.5 & -2.7 & -2.8 \\
\hline Total revenue and grants & 20.5 & 21.6 & 22.2 & 23.4 & 23.3 & 23.4 & 23.0 & 22.7 & 22.6 & 22.6 \\
\hline Revenue & 20.1 & 21.2 & 21.8 & 23.1 & 23.0 & 23.1 & 22.7 & 22.4 & 22.3 & 22.4 \\
\hline Of which: oil revenue & 6.5 & 7.4 & 6.6 & 6.5 & 6.7 & 6.8 & 5.8 & 5.1 & 4.9 & 4.7 \\
\hline Grants & 0.5 & 0.4 & 0.4 & 0.3 & 0.3 & 0.3 & 0.3 & 0.3 & 0.3 & 0.2 \\
\hline Total Expenditure and net lending & 25.5 & 26.6 & 26.8 & 28.4 & 26.8 & 28.1 & 27.7 & 27.4 & 27.3 & 27.3 \\
\hline Current expenditure & 15.9 & 16.0 & 15.8 & 17.0 & 16.3 & 17.6 & 17.1 & 17.0 & 17.2 & 17.4 \\
\hline Capital expenditure & 7.4 & 8.4 & 8.2 & 8.4 & 7.8 & 8.2 & 8.2 & 8.2 & 8.1 & 8.1 \\
\hline \multirow[t]{2}{*}{ Net lending $1 /$} & 2.2 & 2.2 & 2.7 & 2.9 & 2.7 & 2.3 & 2.4 & 2.2 & 2.0 & 1.9 \\
\hline & \multicolumn{10}{|c|}{ (In millions of U.S. dollars; unless otherwise indicated) } \\
\hline Current account balance & 642 & 670 & -421 & $-1,844$ & $-1,942$ & $-2,145$ & $-1,767$ & $-1,331$ & -885 & -688 \\
\hline (In percent of GDP) & 2.1 & 2.1 & -1.2 & -4.7 & -4.4 & -4.5 & -3.5 & -2.4 & -1.5 & -1.1 \\
\hline Trade balance & 378 & 627 & -876 & $-2,510$ & $-2,455$ & $-2,757$ & $-2,461$ & $-1,976$ & $-1,545$ & $-1,349$ \\
\hline Exports & 14,449 & 15,027 & 16,706 & 19,986 & 24,562 & 27,582 & 32,463 & 38,023 & 44,416 & 51,494 \\
\hline (Percentage change) $2 /$ & 25.2 & 4.0 & 11.2 & 19.6 & 22.9 & 12.3 & 17.7 & 17.1 & 16.8 & 15.9 \\
\hline Imports & 14,071 & 14,400 & 17,582 & 22,495 & 27,017 & 30,339 & 34,925 & 40,000 & 45,961 & 52,843 \\
\hline (Percentage change) $2 /$ & 34.5 & 2.3 & 22.1 & 27.9 & 20.1 & 12.3 & 15.1 & 14.5 & 14.9 & 15.0 \\
\hline Net services and transfers (incl. investment income) & 1,476 & 1,250 & 1,898 & 2,239 & 2,339 & 2,439 & 2,650 & 2,760 & 2,870 & 2,980 \\
\hline Of which: private transfers & 1,340 & 1,100 & 1,767 & 2,100 & 2,200 & 2,300 & 2,500 & 2,600 & 2,700 & 2,800 \\
\hline Capital and financial account (net) & -526 & -476 & 885 & 3,992 & 2,313 & 2,378 & 2,764 & 2,750 & 2,772 & 3,295 \\
\hline Direct investment & 1,101 & 1,252 & 2,045 & 1,829 & 1,155 & 1,400 & 2,000 & 2,200 & 2,420 & 2,662 \\
\hline Medium- and long-term loans & 729 & 623 & 526 & 1,047 & 1,454 & 1,532 & 1,518 & 1,384 & 1,266 & 1,231 \\
\hline Of which: ODA disbursements & 1,361 & 958 & 1,073 & 1,258 & 1,419 & 1,500 & 1,400 & 1,300 & 1,100 & 1,000 \\
\hline Short-term capital (net) & $-1,755$ & $-1,532$ & $-1,273$ & 1,706 & 104 & -30 & -150 & -150 & -150 & -150 \\
\hline Changes in reserves (- indicates increase) & -115 & -194 & -464 & $-2,148$ & -384 & -233 & -997 & $-1,419$ & $-1,887$ & $-2,607$ \\
\hline \multicolumn{11}{|l|}{ Memorandum items } \\
\hline Gross official reserves (in billions of US dollars) & 3.0 & 3.4 & 3.7 & 5.6 & 6.2 & 6.2 & 7.2 & 8.7 & 10.5 & 13.1 \\
\hline (in weeks of next year's imports of goods and nonfactor services) & 8.9 & 8.3 & 7.3 & 9.3 & 8.9 & 8.0 & 8.1 & 8.4 & 8.9 & 9.7 \\
\hline Debt service payments (in billions of U.S. dollars) & 1.7 & 1.9 & 1.7 & 1.8 & 1.8 & 1.9 & 2.3 & 2.6 & 3.0 & 3.0 \\
\hline (in percent of exports of goods and nonfactor services) & 10.5 & 10.6 & 8.6 & 7.9 & 6.5 & 6.0 & 6.1 & 6.0 & 5.9 & 5.1 \\
\hline External debt (in billion US dollars) $3 /$ & 11.5 & 12.3 & 12.2 & 13.3 & 15.0 & 16.5 & 17.8 & 19.1 & 20.1 & 21.4 \\
\hline (in percent of GDP) & 38.6 & 37.9 & 34.9 & 34.1 & 34.0 & 34.9 & 35.2 & 34.9 & 33.9 & 33.3 \\
\hline Nominal GDP (US dollars) & 31.2 & 32.5 & 35.1 & 39.0 & 44.1 & 47.3 & 50.7 & 54.7 & 59.2 & 64.3 \\
\hline
\end{tabular}

Sources: Data provided by the authorities; and Fudn staff estimates and projections.

1/ Includes DAF operations.

2/ Growth rates of cumulative exports and imports for the year so far, compared with the same period last year.

3/ Includes the loan component of foreign direct investment and other private sector borrowing and short-term debt. 
Table 7. Vietnam: Indicators of External Vulnerability, 2000-04

\begin{tabular}{|c|c|c|c|c|c|c|}
\hline & 2000 & 2001 & 2002 & 2003 & \multirow{2}{*}{\multicolumn{2}{|c|}{$\begin{array}{l}2004 \\
\text { Proj. }\end{array}$}} \\
\hline & & & & & & \\
\hline \multicolumn{7}{|l|}{ Financial indicators } \\
\hline Public sector debt (in percent of GDP) 1/2/ & 27.7 & 28.9 & 27.6 & 27.3 & 27.4 & \\
\hline Broad money (M2: annual percentage change) 3/ & 39.0 & 25.5 & 17.6 & 24.9 & 26.4 & $7 /$ \\
\hline Foreign currency deposits to broad money (in percent) 3 / & 28.0 & 31.7 & 28.4 & 23.6 & 24.3 & $7 /$ \\
\hline Credit to other (nonstate) sectors (annual percentage change) 3 / & 46.9 & 27.5 & 29.5 & 35.1 & 36.5 & 4/ \\
\hline Foreign currency loans to credit to the economy (in percent) 3 / & 20.7 & 19.3 & 20.0 & 22.0 & 23.3 & $4 /$ \\
\hline \multicolumn{7}{|l|}{ External indicators } \\
\hline Exports value growth (in percent) & 25.2 & 4.0 & 11.2 & 19.6 & 22.9 & \\
\hline Imports value growth (in percent) & 34.5 & 2.3 & 22.1 & 27.9 & 20.1 & \\
\hline Current account balance (in percent of GDP, including official transfers) & 2.1 & 2.1 & -1.2 & -4.7 & -4.4 & \\
\hline Capital account balance (in US\$ billion) & -0.5 & -0.5 & 0.9 & 4.0 & 2.3 & \\
\hline \multicolumn{7}{|l|}{ Of which: } \\
\hline Short-term capital (net) & -1.8 & -1.5 & -1.3 & 0.8 & 0.1 & \\
\hline Gross foreign direct investment (inflows) & 1.1 & 1.3 & 2.0 & 1.8 & 1.2 & \\
\hline Of which: Loans & 0.1 & 0.2 & 0.1 & 0.4 & 0.4 & \\
\hline Medium-and long-term loans (net) & 0.7 & 0.6 & 0.5 & 1.0 & 1.5 & \\
\hline Exchange rate (per U.S. dollar, period average, + dong appreciation) 5/ & 14,170 & 14,806 & 15,272 & 15,514 & 15,767 & $6 /$ \\
\hline (annual percentage change) & -1.6 & -4.5 & -3.1 & -1.6 & -1.6 & \\
\hline Exchange rate (dong per U.S. dollar, end of period, + dong appreciation) 5/ & 14,514 & 15,084 & 15,404 & 15,646 & 15,764 & $6 /$ \\
\hline (annual percentage change) & -3.5 & -3.9 & -2.1 & -1.6 & -0.8 & \\
\hline Real effective exchange rate (end of period, annual percentage change, + appreciation) & 1.6 & 1.3 & -3.6 & -6.7 & 6.3 & \\
\hline \multicolumn{7}{|l|}{ Reserve indicators } \\
\hline Gross official reserves, including gold (in US\$ billion) & 3.0 & 3.4 & 3.7 & 5.6 & 5.8 & $7 /$ \\
\hline (in weeks of next year's imports of goods and nonfactor services) & 8.9 & 8.3 & 7.3 & 9.7 & 9.7 & \\
\hline Net official international reserves (in US\$ billion) & 2.2 & 2.6 & 3.0 & 4.7 & 4.7 & 7/ \\
\hline Gross official reserves to broad money (M2) (in percent) & 19.7 & 18.3 & 17.3 & 21.4 & 20.2 & \\
\hline Gross official to short-term debt (remaining maturity basis) (in percent) & 256 & 425 & 375 & 606 & 598 & \\
\hline Net foreign assets of commercial banks (in US\$ billion) & 2.1 & 1.0 & -0.6 & -1.4 & -0.3 & \\
\hline \multicolumn{7}{|l|}{ Debt indicators } \\
\hline Total external debt (in US\$ billion) 2/ & 12.0 & 12.3 & 12.2 & 13.3 & 15.0 & \\
\hline Of which: Public and publicly guaranteed debt & 8.6 & 9.4 & 9.7 & 10.6 & 12.1 & \\
\hline Total external debt to exports of goods and services (in percent) 2/ & 70.2 & 69.0 & 62.3 & 57.2 & 53.5 & \\
\hline Total debt service to exports of goods and services (in percent) 8/ & 10.3 & 10.6 & 8.6 & 7.9 & 6.5 & \\
\hline Total short-term external debt by remaining maturity (in US\$ billion) & 0.1 & 0.7 & 0.7 & 0.7 & 0.7 & \\
\hline Total short-term external debt by remaining maturity to total debt (in percent) & 1.0 & 5.6 & 5.3 & 5.4 & 4.7 & \\
\hline \multicolumn{7}{|l|}{ Financial market indicators } \\
\hline Ho Chi Minh City Stock Exchange Composite Index (end of period, July $2000=100$ ) & 207 & 235 & 183 & 150 & 232 & 9/ \\
\hline Number of listed companies & 5 & 12 & 21 & 21 & 25 & 9/ \\
\hline
\end{tabular}

Sources: Vietnamese authorities; and Fund staff estimates and projections.

1/ Excludes domestic debt and unguaranteed external debt of state-owned enterprises.

2/ Restructuring of nonconvertible Russian debt was concluded in September 2000.

3/ Starting in 2000, based on expanded monetary survey (currently comprising the State Bank of Vietnam (SBV) and 84 credit institutions); for previous periods, based on original monetary survey (SBV and 28 credit institutions).

4/ June.

5/ Official mid-rate, which comprises the previous day's average interbank buying and selling rates.

6/ August.

7/ July.

8/ Accrual basis.

9/ September. 


\section{Vietnam-Fund Relations}

(As of August 31, 2004)

I. Membership Status: Joined: 09/21/1956; Article XIV

II. General Resources Account:

Quota

Fund Holdings of Currency

Reserve position in Fund

III SDR Department:

Net cumulative allocation

Holdings

IV. Outstanding Purchases and Loans:

PRGF arrangements

$\begin{array}{cc}\text { SDR Million } & \text { Percent Quota } \\ 329.10 & 100.00 \\ 329.10 & 100.00 \\ 0.01 & 0.00\end{array}$

$\underline{\text { SDR Million }}$

47.66

0.38

$\underline{\text { SDR Million }}$

196.68 $\underline{\text { Percent Allocation }}$

100.00

0.79

Percent Quota

59.76

V. Financial Arrangements:

\begin{tabular}{|c|c|c|c|c|}
\hline Type & $\begin{array}{c}\text { Approval } \\
\text { Date } \\
\end{array}$ & $\begin{array}{c}\text { Expiration } \\
\text { Date } \\
\end{array}$ & $\begin{array}{c}\text { Amount Approved } \\
\text { (SDR Million) }\end{array}$ & $\begin{array}{l}\text { Amount Drawn } \\
\text { (SDR Million) }\end{array}$ \\
\hline PRGF & $04 \overline{/ 13 / 2001}$ & $\overline{04 / 12 / 2004}$ & 290.00 & 124.20 \\
\hline ESAF & $11 / 11 / 1994$ & $11 / 10 / 1997$ & 362.40 & 241.60 \\
\hline Stand-by & $10 / 06 / 1993$ & $11 / 11 / 1994$ & 145.00 & 108.80 \\
\hline
\end{tabular}

VI. Projected Obligations to Fund (in SDR Million; based on existing use of resources and present holdings of SDRs):

\begin{tabular}{lrrrrr} 
& \multicolumn{5}{c}{ Forthcoming } \\
\cline { 2 - 6 } & $\underline{2004}$ & $\underline{\underline{2005}}$ & $\underline{\underline{2006}}$ & $\underline{\underline{2007}}$ & $\underline{\underline{2008}}$ \\
Principal & 18.12 & 36.24 & 22.26 & 16.56 & 24.84 \\
Charges/Interest & 0.71 & 1.73 & 1.60 & 1.50 & 1.39 \\
Total & 18.83 & 37.97 & 23.86 & 18.06 & 26.23
\end{tabular}

\section{Exchange Rate Arrangement and Exchange Restrictions:}

On February 25, 1999 the State Bank of Vietnam (SBV) revised the operation of the interbank foreign exchange market. Under this de facto managed floating regime, the SBV allows interbank foreign exchange market rates to fluctuate by a maximum of \pm 0.25 percent a day (effective July 2002) from the previous day’s average interbank market rate.

Vietnam currently maintains the following exchange restrictions subject to Fund jurisdiction under Article VIII: (i) a foreign exchange balancing requirement applying to foreign invested 
companies - i.e., enterprises whose capital is fully or partially owned by foreigners - such that the ability of the companies to make payments and transfers for current international transactions is contingent on their capability of generating foreign exchange and not on their foreign exchange needs; (ii) limitations on the availability of foreign exchange for payments of moderate amounts of amortization of loans or for depreciation of investment under the definition of current international payments, which is not aligned with the definition of current international payments in Article XXX (d) of the Fund's Articles of Agreement; (iii) the existence of a group of "non-priority" import payments corresponding to non-priority import goods, implying that banks would require such customers to generate their own foreign exchange for such import payments, even though the underlying import transaction would be allowed; and (iv) a requirement that residents and nonresidents fulfill all tax obligations before payments and transfers for current international transactions may be made. The exchange restrictions described have not been approved by the Executive Board.

\section{Article IV and XIV Consultations:}

Vietnam is currently on a 24-month consultation cycle, subject to provisions of Board Decision No. 12794-(02/76) of July 15, 2002. The last Article IV and Article XIV consultations were concluded by the Executive Board on October 3, 2003. Since the PRGF has expired, it is expected to be on a standard 12-month cycle.

Vietnam continues to maintain restrictions on the making of payments and transfers for current international transactions under the transitional arrangements of Article XIV, Section 2. The Fund encourages Vietnam to eliminate these restrictions as soon as circumstances permit.

\section{Technical Assistance:}

See TA matrix.

\section{In-Country Training/Outreach:}

- $\quad$ Workshop on Macroeconomic Policies for Parliamentarians (EXR/APD/INS), March 2004.

- 10-session Seminar for Parliamentarians on the Fundamentals of Macroeconomics (APD), October-December 2003.

- $\quad 10$-session Seminar on Topics in Financial Programming for State Bank of Vietnam and related Government Agencies (APD), January-May 2002.

\section{Other Visits}

The Managing Director, Mr. de Rato, visited Vietnam in June 2004.

\section{Resident Representative}

Mrs. Susan Adams has been the Senior Resident Representative since August 2001. 
Vietnam-Summary of Fund Technical Assistance, 2000-04

\begin{tabular}{|c|c|c|}
\hline Department & Purpose & Date \\
\hline \multicolumn{3}{|c|}{ Tax self-assessment pilot projects } \\
\hline $\begin{array}{l}\text { FAD } \\
\text { FAD } \\
\text { FAD } \\
\text { FAD } \\
\text { FAD } \\
\text { FAD }\end{array}$ & $\begin{array}{l}\text { Tax self-assessment pilot preparations } \\
\text { Tax self-assessment pilot preparations } \\
\text { Tax self-assessment pilot preparations } \\
\text { IT for Tax self-assessment pilot preparations } \\
\text { Tax self-assessment pilot preparations } \\
\text { Assessment of training needs and organization change } \\
\text { Tax self-assessment pilot preparations } \\
\text { Tax self-assessment pilot preparations } \\
\text { Introduction of self assessment and reform of the tax administration } \\
\text { taxpayers services; debt collection } \\
\text { Assessment of tax self-assessment pilot implementation and } \\
\text { planning for the future } \\
\text { Strategic planning and tax self-assessment pilot implementation } \\
\text { Tax self-assessment pilot implementation }\end{array}$ & $\begin{array}{l}\text { June-July } 2002 \\
\text { November-December } 2002 \\
\text { March-April } 2003 \\
\text { May } 2003 \\
\text { August } 2003 \\
\text { September } 2003 \\
\text { November } 2003 \\
\text { February-March } 2004 \\
\text { April } 2004 \\
\text { June-July } 2004 \\
\text { August } 2004\end{array}$ \\
\hline \multicolumn{3}{|c|}{ Tax policy and Administration reform } \\
\hline $\begin{array}{l}\text { FAD } \\
\text { FAD } \\
\text { FAD } \\
\text { FAD } \\
\text { FAD } \\
\text { FAD }\end{array}$ & $\begin{array}{l}\text { Review the status of implementation of tax policy and administration } \\
\text { reform } \\
\text { Tax policy and administration reform } \\
\text { Tax policy and administration reform } \\
\text { Tax policy and administration reform } \\
\text { Tax policy and administration reform } \\
\text { Assessment of the major taxes }\end{array}$ & $\begin{array}{l}\text { July-August } 2001 \\
\text { February-March } 2002 \\
\text { July } 2003 \\
\text { November } 2002 \\
\text { May-June } 2003 \\
\text { May-June } 2004\end{array}$ \\
\hline \multicolumn{3}{|c|}{ SOCB restructuring } \\
\hline $\begin{array}{l}\text { MFD } \\
\text { MFD } \\
\text { MFD } \\
\text { MFD }\end{array}$ & $\begin{array}{l}\text { SOCB restructuring } \\
\text { SOCB restructuring } \\
\text { SOCB restructuring } \\
\text { Bank analysis, banking regulation and supervision, monetary operations } \\
\text { and related foreign exchange issues, and central bank organization }\end{array}$ & $\begin{array}{l}\text { September } 2002 \\
\text { November } 2002 \\
\text { June } 2003 \\
\text { February } 2004\end{array}$ \\
\hline \multicolumn{3}{|c|}{ SOCB Restructuring and foreign reserve management } \\
\hline MFD & Banking system restructuring and foreign exchange operations at the SBV & August-September 2001 \\
\hline \multicolumn{3}{|c|}{ Safeguards-related TA } \\
\hline $\begin{array}{l}\text { MFD/FIN } \\
\text { MFD/FIN } \\
\text { MFD/FIN }\end{array}$ & $\begin{array}{l}\text { Safeguards-related TA } \\
\text { Safeguards-related TA } \\
\text { Safeguards-related TA }\end{array}$ & $\begin{array}{l}\text { September } 2002 \\
\text { December } 2002 \\
\text { June } 2003\end{array}$ \\
\hline \multicolumn{3}{|c|}{ Banking supervision } \\
\hline MFD & Banking supervision & August 2004 \\
\hline
\end{tabular}


Vietnam-Summary of Fund Technical Assistance, 2000-04

\begin{tabular}{|c|c|c|}
\hline Department & Purpose & Date \\
\hline \multicolumn{3}{|c|}{ Strengthening the SBV audit capacity in the SAO } \\
\hline $\begin{array}{l}\text { MFD } \\
\text { MFD }\end{array}$ & $\begin{array}{l}\text { Strengthening SBV audit capacity in the SAO } \\
\text { Strengthening SBV audit capacity in the SAO }\end{array}$ & $\begin{array}{l}\text { December } 2003 \\
\text { October } 2004\end{array}$ \\
\hline \multicolumn{3}{|c|}{ Anti-money laundering } \\
\hline MFD/LEG & $\begin{array}{l}\text { TA program for anti-money laundering and combating the financing of } \\
\text { terrorism }\end{array}$ & December 2003 \\
\hline \multicolumn{3}{|c|}{ National Income Account and Statistics } \\
\hline $\begin{array}{l}\text { STA } \\
\text { STA } \\
\text { STA } \\
\text { STA } \\
\text { STA }\end{array}$ & $\begin{array}{l}\text { Improvement plan of the real sector statistics project development } \\
\text { National Income Account and Statistics } \\
\text { National Income Account and Statistics } \\
\text { National Income Account and Statistics } \\
\text { National Income Account and Statistics }\end{array}$ & $\begin{array}{l}\text { December } 2001 \\
\text { August-September } 2002 \\
\text { May-June } 2003 \\
\text { February-March } 2004 \\
\text { September } 2004\end{array}$ \\
\hline \multicolumn{3}{|c|}{ Multisector statistics/GDDS } \\
\hline STA & $\begin{array}{l}\text { Guidance on statistical practices and development in the areas of national } \\
\text { accounts, prices, foreign trade, fiscal and socio-demographic data }\end{array}$ & July 2001 \\
\hline \multicolumn{3}{|c|}{ Balance of payment statistics } \\
\hline STA & $\begin{array}{l}\text { TA in BOP statistics and guidance in the development of international } \\
\text { investment position statistics }\end{array}$ & September 2003 \\
\hline \multicolumn{3}{|c|}{ Debt sustainable analysis } \\
\hline PDR & Debt sustainable analysis & October 2002 \\
\hline \multicolumn{3}{|c|}{ Tax administration law } \\
\hline LEG & Tax law & February 2004 \\
\hline \multicolumn{3}{|c|}{ Access to international capital market } \\
\hline $\mathrm{ICM}$ & Access to international capital market & May-June 2004 \\
\hline
\end{tabular}




\section{Vietnam- Relations with the World Bank ${ }^{11}$}

\section{Partnership in Vietnam’s DeVelopment Strategy}

The government of Vietnam's development strategy is set forth in its Comprehensive Poverty Reduction and Growth Strategy (CPRGS). The CPRGS focuses on: (i) high growth through a transition to a market economy, (ii) an equitable, socially inclusive, and sustainable path of growth, and (iii) the adoption of a modern public administration, legal, and governance system. A Joint Staff Assessment of the CPRGS was discussed by the Boards of the IMF and the World Bank in June and July 2002, respectively. A Joint Staff Assessment of the first Progress Report of the CPRGS was discussed by the two Boards in February, 2004.

The World Bank has taken the lead in supporting the Government's structural and institutional reforms in a number of sectors, and has backed the reform program through a series of Poverty Reduction Support Credit (PRSCs). The first PRSC, for US\$250 million, included measures to: (i) liberalize foreign trade; (ii) restructure or divest SOEs; (iii) strengthen the banking system; (iv) create a better climate for the development of the domestic formal private sector; and (v) improve the efficiency, equity, and transparency of public spending. The final tranche was disbursed in December 2002. This PRSC was cofinanced by the UK, Netherlands, Denmark, and Sweden.

The second PRSC, signed in August 2003, was broader in scope. It extended beyond the structural reform agenda and included measures related to socially inclusive development and to modern governance. This second PRSC translated the development vision of CPRGS into a series of concrete policy measures, and laid the foundation for a series of annual PRSCs, until the revision of CPRGS, currently expected in 2006. It also established a series of triggers to assess the pace of policy reform, and linked this to the size of subsequent budget-support operations. The second PRSC, for US\$100 million, was co-financed by the UK, Netherlands and Denmark.

The third PRSC, approved by the Board in June 2004, endorses policy actions that are firmly rooted in the CPRGS and other development plans and strategies with a strong Government ownership. In so doing, it further deepens the reforms supported under the previous two PRSCs and the PRGF. The credit identifies actions to support the unfinished reform agenda, including the preparations for Vietnam's early accession to the WTO, SOE and SOCB reform, further progress in planning processes, and public financial management, and the move towards a more systematic approach to fighting corruption. The third PRSC, for US\$ 100, is co-financed by seven bilateral and multilateral donors: the Asian Development Bank,

\footnotetext{
${ }^{11}$ Contact person: Ms. Keiko Sato
} 
the Canadian International Development Agency, Denmark, the European Commission, the Japan Bank for International Cooperation, Netherlands, and the United Kingdom's Department for International Development. Combined, this co-financing exceeds the amount of the credit itself.

\section{WORLD BANK GROUP STRATEGY AND LENDING}

The World Bank Group is combining all of its instruments of assistance to support the objectives laid out by the CPRGS. Those instruments include analytical and advisory activities, IDA project support, IFC, Mekong Project Development Facility (MPDF) and MIGA activities, a series of PRSCs, and partnerships and ODA coordination. An update of the Country Assistance Strategy, presented to the World Bank Board in January 2004, sets out the planned support of the CPRGS objectives until the Bank's FY06..

Virtually all IDA credits will support policy, institutional and infrastructure development for Vietnam's ongoing transition, with the planned series of PRSCs being used as vehicles for the policy dialogue.

Several priorities are identified by the CPRGS to enhance equitable, inclusive, and sustainable development. They refer to disadvantaged and lagging areas, to the living standards of ethnic minorities, to gender equality, to access and affordability of social services for the poor, to the mitigation of impacts from natural disasters, and to enhancing environmental management. The World Bank favors a sector-wide approach for two projects supporting this agenda, Rural Roads III and Education for All. Sectoral budget support requires significant progress in the preparation of medium term expenditure frameworks, as well as improved transparency and financial management.

Efforts to improve governance will focus on public financial management, information and transparency, and legal development. Major technical assistance will be provided by the World Bank in each of these areas. An IDA project is being implemented in Public Financial Management and one on Customs Modernization is under preparation. So far, AsDB, UNDP, and a number of donors have taken the lead on public administration and civil service reform, whereas the World Bank plays the leading role in public financial management.

The CPRGS is widely recognized as a blueprint for development with strong national ownership. It is now clear that the CPRGS approach will be mainstreamed into the 2006-10 five year-plan. At the same time, the momentum of reform has been energized by the ongoing preparation for WTO accession. Over the past twelve months, the Government has been actively working on the preparation of roadmaps for WTO accession for key sectors of the economy. This work was supported by the World Bank. Securing compliance with WTO rules, will be a powerful mechanism to lock-in reforms, especially on "behind-the-border" issues.

The scale of the lending program depends on the pace of the policy and institutional reform agendas, as well as on progress in project preparation and implementation. A CAS Progress Report was endorsed by the Board in February 2004 with a revised and expanded operational 
program for FY04-06 of $\$ 750$ million per year in the base case and $\$ 900$ million in the high case. In FY04, Vietnam was the largest recipient of IDA funds with total commitments of $\$ 705$ million. The IFC and MIGA programs are also expected to grow significantly as the investment climate improves.

In addition to its lending program, the World Bank will work in capacity-building and knowledge-sharing in key areas of emphasis. A Banking Sector Review was completed in 2002. A new household survey, the 2002 Vietnam Household Living Standards Survey, was used as the basis for the Vietnam Development Report, titled"Poverty" in FY04. An integrated Public Expenditure Review-Integrated Fiduciary Assessment was launched in FY04 and is due to be finalized in FY05. Annually, the Vietnam Development Report, coauthored by a number of donors and NGOs, summarizes the accumulated knowledge and fosters the policy and institutional reform agenda.

The World Bank has worked closely with the Ministry of Finance, the National Steering Committee on Enterprise Reform and Development and the Ministry of Labor, Invalids and Social Affairs in all areas of the SOE reform program. In parallel it has mobilized resources from various donors to carry out the various activities. The World Bank plays a key role in the monitoring of ownership transformation (especially equitizations, sales and liquidations) and SOE creation. A series of operational reviews of large enterprise groupings are being implemented with the objective of assessing SOE viability and financial position. Restructuring three General Corporations (large SOE groupings) in sectors where Vietnam has comparative advantage in world markets is also a priority. The design and implementation of the social safety net for redundant SOE workers has been an integral part of the World Bank's work program. The World Bank is now turning its attention to assisting in setting up the operations of the Debt Asset Trading Company (DATC), and towards improving the monitoring SOE performance.

In the area of public expenditure management, key remaining challenges include:

(i) integrating formulation of the recurrent and capital budgets within a medium-term expenditure framework; (ii) improving budgetary data and increasing the transparency of data and information flows; and (iii) ensuring an effective process for prioritizing and reallocating public expenditures to improve sector outcomes, reduce poverty and limit the prospective increase in inequality. To meet these challenges, the Government launched the Public Financial Management Reform Initiative (PFMRI), a medium-term program for strengthening public financial management. This overarching program deals with reforms in five areas: public expenditure management (including state budget management, investment planning, and financial management information); public debt management; revenue management; SOE fiscal risk management; and public asset management.

Jointly with other donors, the World Bank is also supporting an effort to modernize planning and budgeting processes at the provincial level. This effort is part of a broader attempt by the Government of Vietnam to "roll out" CPRGS to the provinces. The goal of the exercise is for local policy makers to identify monitorable targets related to growth and poverty 
reduction, to align resources to the attainment of those targets, and to introduce mechanisms for consultation with the local population.

The World Bank, which has had a long-term role in the modernization of the financial sector, has taken the lead in the effort to strengthen the banking system. Input has been provided by way of direct technical assistance and policy dialogue, with the aim of rationalizing the Joint Stock Banks, strengthening of State-Owned Commercial Banks (SOCBs), improving the supervision of the system, and modernizing the infrastructure for banking. The areas of work with the SOCBs have included the resolution of Non-Performing Loans (NPLs), provisioning for loan loss, re-capitalizing banks as they meet their restructuring targets, introducing internal auditing, and developing a viable payments system. Current efforts aim at improving the regulatory framework for policy lending, and at developing more effective mechanisms for NPL resolution.

The IMF and the World Bank currently collaborate to strengthen the capacity of the General Statistics Office in the area of economic statistics. The IMF focuses on improving balance of payments, national accounts, and price statistics while the World Bank concentrates on issues related to the production of high-quality household and enterprise surveys, and to access to data. 


\section{Vietnam-Relations with the Asian Development Bank}

The Asian Development Bank (ADB) resumed its operations in Vietnam in October 1993. The new Country Strategy and Program (CSP), endorsed in January 2002, proposes a focus on four pillars to align ADB operations in Vietnam to the overarching objective of poverty reduction: (i) sustainable growth through rural development and private sector development, with a focus on small and medium enterprise development; (ii) inclusive social development, by mainstreaming poverty, gender, and ethnic dimensions in ADB operations, with an emphasis on human capital development through secondary education and health; (iii) good governance, with special emphasis on public administration and civil service reform; and (iv) geographic focus on the impoverished central region.

From October 1993 to June 2004, ADB approved 44 loans totaling about US\$2.6 billion from the concessional Asian Development Fund (ADF) and US\$40 million from Ordinary Capital Resources (OCR). Disbursements in 2003 totaled US\$233.1 million, and in the first six months of 2004, US\$54.2 million. Since December 1998, Vietnam has been classified as a B-1 country by ADB, which makes it eligible to supplement borrowing at ADF terms with borrowing at non-concessional (OCR) terms. Loans have been provided mainly for (i) rehabilitating physical infrastructure in the agricultural, energy, and transport sectors; (ii) financial sector reform with focus on non-banking sector; (iii) public administration reform; and (iv) preventive heath care and secondary education. In addition, ADB has extended technical assistance (TA) amounting to US\$101.21 million for 148 projects as of end June 2004.

Support for policy and structural reforms to improve public sector efficiency and to encourage the development of the private sector is a vital component of ADB operations in Vietnam. So far, ADB has approved seven policy-based program loans in the agricultural sector (US\$80 million in 1994 and US\$60 million in 2002), the financial sector (US\$90 million in 1996 and US\$50 million in 2002), for SOE reform and corporate governance (US\$100 million in 1999, of which US\$40 million was from OCR), and for public administration reform (US\$45 million in 2003). In addition to program lending, policy dialogue is an important feature in all of ADB's loan projects in Vietnam. This includes support for private sector development and increased efficiency of state-owned utilities through reforming their rate structure and other measures to increase cost recovery and to strengthen financial management, policy analysis, and planning.

ADB was reorganized in 2002, and Vietnam belongs to the Mekong Department, along with Cambodia, Lao PDR, Myanmar, and Thailand. The Vietnam Resident Mission has been strengthened and has been performing programming functions. During the past year, ADB has helped the government organize regional consultations and poverty assessments to analyze Vietnam's achievements against development targets in the areas of public service delivery to people and business and good governance as part of the roll-out process of the national strategy for growth and poverty reduction. ADB and Fund staff work closely together to support the process of economic reforms in Vietnam. ADB staff participate in Fund missions, exchange information, and consult on macroeconomic developments and policy matters. The resident missions of the two institutions also cooperate closely. 
Table 1. Vietnam: Public Sector Assistance by Sector

October 1993-June 2004

(In millions of U.S. dollars)

\begin{tabular}{lcc}
\hline Sector & Number & Approval Amount \\
\hline Lending & 44 & 2665.2 \\
Agriculture and Natural Resources & 15 & 877.4 \\
Social Infrastructure & 14 & 719.3 \\
Transportation and Communication & 7 & 595.0 \\
Finance & 2 & 140.0 \\
Energy & 2 & 180.0 \\
Industry and Non-fuel Minerals & 2 & 100.0 \\
Others & 2 & 53.5 \\
Technical assistance & & 101.21 \\
Advisory & 148 & 69.36 \\
Project Preparation & 107 & 31.85 \\
\hline
\end{tabular}

Source: ADB.

Table 2. Vietnam: Loan and TA Approvals and Disbursements, 1999-2004 (In millions of U.S. dollars)

\begin{tabular}{lrrrrrr}
\hline & 1999 & 2000 & 2001 & 2002 & 2003 & $20041 /$ \\
\hline Loan Approvals & 220.0 & 188.5 & 243.1 & 233.5 & 179.0 & 20.0 \\
& 191.2 & 218.9 & 176.2 & 231.7 & 233.1 & 54.2 \\
Loan Disbursements & 1191.6 & 1190.4 & 1086.2 & 1118.8 & 1198.1 & 1191.6 \\
$\begin{array}{l}\text { Undisbursed Balance at the } \\
\text { Beginning of the year }\end{array}$ & 10.3 & 9.1 & 8.4 & 9.3 & 8.6 & 0.5 \\
$\begin{array}{l}\text { Memorandum item: } \\
\text { TA Approvals }\end{array}$ & & & & & & \\
\hline
\end{tabular}

Source: ADB.

1/ As of 30 June 2004. 


\section{Vietnam-Statistical Issues}

The reliability and coverage of macroeconomic statistics have significant deficiencies. The methodology for compilation and dissemination of these statistics continues to need substantial improvement, so that data properly reflect economic developments and assist policy formulation, implementation, and monitoring. The authorities are cooperating with the Fund, but work is hampered in some areas by the lack of authorization to release data. Vietnam has few official statistical publications that provide coverage beyond the real sector. A Vietnam page was introduced in the GFS Yearbook in 1999 and in IFS in 2001.

Vietnam has become a subscriber to GDDS participant, with its metadata posted on the IMF's Dissemination Standards Bulletin Board since September 2003.

\section{National accounts}

The General Statistical Office (GSO) disseminates quarterly and annual data on gross domestic product (GDP) by type of economic activity and annual data by category of expenditure ${ }^{12}$ (both in current and constant prices). While the methodology for producing national accounts is broadly consistent with the System of National Accounts 1993, the compilation process suffers from poor data collection practices and a lack of coordination and communication between data collection agencies.

Estimates of GDP by expenditure have been produced since 1993, but they are in highly aggregated form. Although coverage has been broadened recently, the authorities need to focus on improving data collection from the nonstate sector (including non-observed activities), which remains quite weak. The lack of frequent surveys on consumption and investment severely limit the calculation of GDP by type of expenditure. In addition, much of the data on national accounts are compiled before the end of the reference period, requiring data providers to resort to forecasting data in the remaining period in order to derive relevant estimates.

Under the current project the expert will assist the GSO in the following areas: promoting the effective use of enterprise and economic census data in compiling the national accounts statistics, improving estimates of GDP at constant prices, estimates of household final consumption expenditure, and estimates of quarterly GDP; developing foreign trade and producer price indices, and wage indices. The consultant has noted steady progress by the GSO in these areas.

Fund staff considered that there was no need to keep a different GDP series from official GDP figures after discussions held in a May 2004 visit on national accounts. The enactment of a

\footnotetext{
${ }^{12}$ Quarterly GDP by type of expenditure was calculated for the period between 2002Q1 to 2003Q2, but has since been discontinued due to lack of resources.
} 
Statistics Law in January 2004 to strengthen the coordination among GSO and ministries and agencies is expected to improve data collection. Two new handbooks on sources and methods for the Vietnam System of National Accounts and the Quarterly National Accounts were published in 2003 in Vietnamese aiming to increase the quality of the estimates and transparency. The GSO has improved its capacity building and is participating in the International Comparison Program in order to produce GDP estimates comparable across countries.

\section{Prices}

The GSO has compiled and published a monthly consumer price index (CPI) in line with international standards since January 1996. Effective July 2001, the GSO changed the CPI to reflect a larger nonfood weight and broader consumption basket based on data from the 1998 Vietnam Household Living Standard Survey (VHLSS) rebased to 2000. The GSO plans to revise the weights when the for 2004 VHLSS becomes available. The publication of a producer price index was planned in late 2001, but has been delayed for technical reasons. Trade price indices are also compiled, but are not used in the national accounts estimation process because the sample size is deemed too small. The recent spike in inflation has greatly increased the authorities' interest in improving Vietnam's price indices, in particular constructing a core inflation index. The authorities requested Fund technical assistance in this area.

\section{Government finance statistics}

The Ministry of Finance's (MoF) State Budget Department produces provisional monthly, quarterly, and annual fiscal data on government operations shortly after the end of the reference period; final data for the fiscal (calendar) year are produced after a delay of about six months. These data reflect the consolidated operations of the state budget, which covers all four levels of government: central, provincial, district, and commune. They exclude data on quasi-fiscal activities of SOEs and non-budgetary funds, among which are the Social Security Fund, Enterprise Restructuring Fund, Development Assistance Fund, Export Support Fund, and Sinking Fund (for repayment of onlent funds), for which no regularly reported data are currently compiled.

Recording is mainly on a cash basis for final annual data, but provisional data differ depending on their source. As a result, government financing data, in particular domestic bank financing, cannot be reconciled as reported in the fiscal and monetary accounts. Like the national accounts, provisional data are compiled before the end of the reference period and thus involve a forecasted component. The quarterly data are only revised when data are compiled for the same quarter of the following year. The MoF's External Finance Department maintains a centralized record of all general government external debt, excluding guarantees issued on behalf of stateowned enterprises. The MoF, with support from the UNDP, aims to strengthen the external debt management system, particularly the recording of disbursements and multiple currency loans.

Despite these shortcomings, the authorities have made progress in a number of other areas related to fiscal transparency, including implementation of an improved budget management law and adoption of a 1986 GFS-consistent budget classification at all levels of government. The 
authorities published for the first time in late 1998 the fiscal outturn for 1997 and the approved budget for 1999, although both in highly aggregated form. Starting in late 2001, the MoF began posting annual budget outturns and plans on its external website, including by major revenue and expenditure items. However, considerable actions remain to be taken to improve the coverage of fiscal data as recommended in the 1998 Bank-Fund report on fiscal transparency, the 2000 Public Expenditure Review, and, most recently, the STA multisector statistics mission.

In this context, the government continues to work toward gazetteing and publishing the annual national budget, as well as having commune-level budgets, implementing the GFS-based functional budget classification system, initiating work on revising government accounting standards, and introducing an integrated financial management system (IFMS) for improving treasury management and fiscal reporting. The STA mission found that the functional classification had not yet been fully aligned with internationally recognized classification standards, which might hamper formulation, execution, and monitoring of fiscal policy. The IFMS will allow a detailed classification of provisional budget data (as well as final accounts). In addition, it will incorporate data on extrabudgetary funds into the Treasury database.

\section{Monetary and financial statistics}

Since the expiration of the PRGF in April 2004, there have been considerable delays in monetary and financial data reporting. Under the PRGF, the State Bank of Vietnam (SBV) used to regularly report monetary and financial data to the Fund, including: (i) the monetary survey and the central bank balance sheet (both on a monthly basis and typically with a six-week lag); (ii) detailed consolidated balance sheets ("derivation tables") for six state-owned and 78 nonstate deposit money banks and individual balance sheets for the four large state-owned commercial banks (SOCBs) (since the beginning of 2001 on a monthly basis and typically with an eightweek lag); (iii) deposit and lending rates of the large SOCBs (on a monthly basis and for various maturities), and (iv) gross and net international reserves data (on a monthly basis and typically with a six-week lag). The 2004 Article IV mission urged the authorities to provide data on a more timely basis.

In January 1999, the SBV and commercial banks began implementing new charts of accounts for compiling money and banking data, developed with STA assistance. The new charts of accounts were formally adopted in April 1999. However, they do not adequately sectorize credit for monetary programming purposes, in particular failing to distinguish between bank credit to stateowned enterprises (SOEs) and to other nonstate sectors of the economy. Therefore, in addition to its regular monthly reports, the SBV has designed a new monthly report form for the four large SOCBs for submitting sectorized credit data to the central bank. Moreover, the STA mission in July 2001 encouraged the SBV to develop a reporting scheme for a comprehensive breakdown of banks' credit to the economy by borrowing sectors, subsectors, and ownership of enterprises.

\section{External sector statistics}

The SBV compiles quarterly and annual balance of payments (BOP) data with a one- to twomonth lag, although the data reported to the Fund for publication are less timely - the data 
published in the August 2004 issue of the IFS are for the fourth quarter of 2002. Since 1995, monthly and annual trade data have been compiled using customs reports, but the coverage and accuracy of these data need to be improved. In particular, the commodity breakdown of a large share of monthly reported exports (approximately 30 percent) is unknown. Published trade data, however, contain a number of adjustments to the customs reports, which have been difficult to reconcile, as the staff is only provided data at a relatively high level of aggregation. Data on invisibles continue to be based largely on banking records, which provide incomplete coverage and identification of the types of transactions. Improvements in BOP statistics, in particular foreign direct investment (FDI), also continue to be hampered by interagency coordination problems.

Data on FDI are now compiled by the SBV based on quarterly and semi-annual survey reports received from foreign-invested enterprises operating in Vietnam and supplemented by reports from SBV branches. The Ministry of Planning and Investment (MPI) also collects administrative data on FDI. However, at the September 2000 ASEAN Workshop on Improving the Quality of FDI Data, the Vietnamese authorities indicated that problems persisted with the survey response rate, as not all FDI enterprises were providing the requested information. Moreover, the 2001 STA GDDS mission noted that no effort was made to distinguish head office and other nonresident liabilities in the reported data.

Data on contracting of commercial debt (by SOEs and privately owned firms) are maintained by the SBV. Some loans are reported only after an extended delay, and the reporting of disbursements and repayments remains poor. Data on contracting, disbursement, and service of official debt are maintained by the MoF. The MPI also reports the loan obligations of foreign investors. The STA mission found that the overlapping responsibility for debt statistics has at times resulted in some deficiencies in coverage, including the lack of monitoring certain leasing arrangements (e.g., for aircraft). 


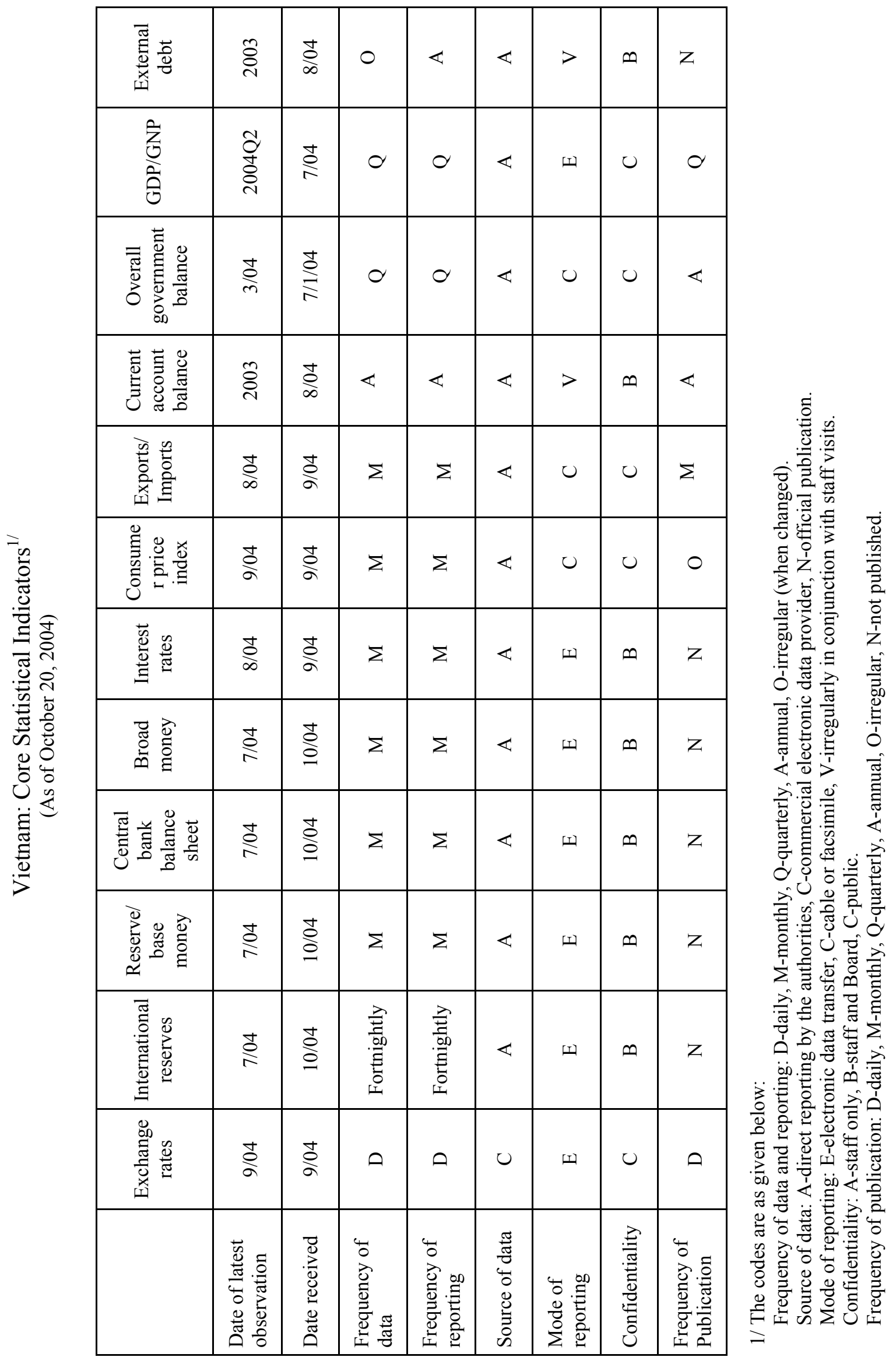




\section{Vietnam-Debt Sustainability Analysis}

Under the baseline scenario, public debt increases from 50 percent of GDP in 2003 to 59 percent of GDP in 2009, and declines thereafter (Table 1a). ${ }^{13}$ In net present value (NPV) terms, public debt peaks at 56 percent of GDP in 2021, up from 40 percent of GDP in 2003. The exercise assumes (i) real growth of 7 percent, (ii) a budget deficit including net lending of 4.7 percent of GDP, equal to the 2005 budget target and close to the historical average, (iii) recognition of SOCB contingent liabilities equivalent to 15 percent of GDP at end-2003 as estimated by the staff, and (iv) significant progress in SOCB reform which would allow SOCBs to begin generating sufficient profits to cover additional provisioning requirements over the medium term. The deficit is increasingly funded domestically and, starting in 2010, through foreign borrowing on commercial terms. As a result, the share of concessional debt falls from about 45 percent in the years 2003-07 to 7 percent in 2023.

The extent of existing SOCB liabilities and the pace of SOCBg reform are subject to considerable uncertainty. Nevertheless, the assumption that the quality of SOCB lending will improve as assumed in the baseline scenario could be optimistic and thus the medium-term deficit target of 4.7 percent of GDP should be considered an upper bound estimate for a sustainable fiscal stance. This is further underlined by the stress tests (Table 1b); a less ambitious fiscal adjustment (tests A1 and A2) or a permanent reduction of growth by a mere $1 / 2$ percentage point (test A3) would lead to steady increases in the NPV-to-GDP ratio.

Vietnam's external debt level is deemed sustainable under the baseline scenario, with external debt projected to increase moderately through 2006 before steadily declining over the long term. As of end-2003, it is estimated that Vietnam's external debt is around 34 percent of GDP, or its NPV is 39 percent of exports. They are projected to be about 35 and 29 percent, respectively, by 2008. The external debt accumulation over the medium term would mainly result from sizable external trade deficits, a large part of which is envisaged to be offset by strong net current transfers (i.e., private remittances). The debt build-up is also expected to be mitigated by sustained net FDI inflows.

Alternative scenarios and bound tests are constructed to examine the sensitivities of the baseline projection of public and publicly guaranteed external debt to a range of potential shocks (Tables 2a and 2b). Several factors that may potentially jeopardize Vietnam's external debt sustainability are identified, including: i) a significant deterioration in the terms of Vietnam's external financing (alternative scenario A2); ii) a substantially weaker export performance due to, for example, a sudden loss of market access to major markets (bound

${ }^{13}$ Public debt is defined on a gross basis and excludes debt by SOEs. It includes extrabudgetary borrowing by the DAF and costs of SOE and SOCB reform (Tables 1a and 1b). 
test 2); and iii) a significant decline in non-debt-creating inflows stemming from deterioration of domestic business environment or external shocks (bound test 4). 


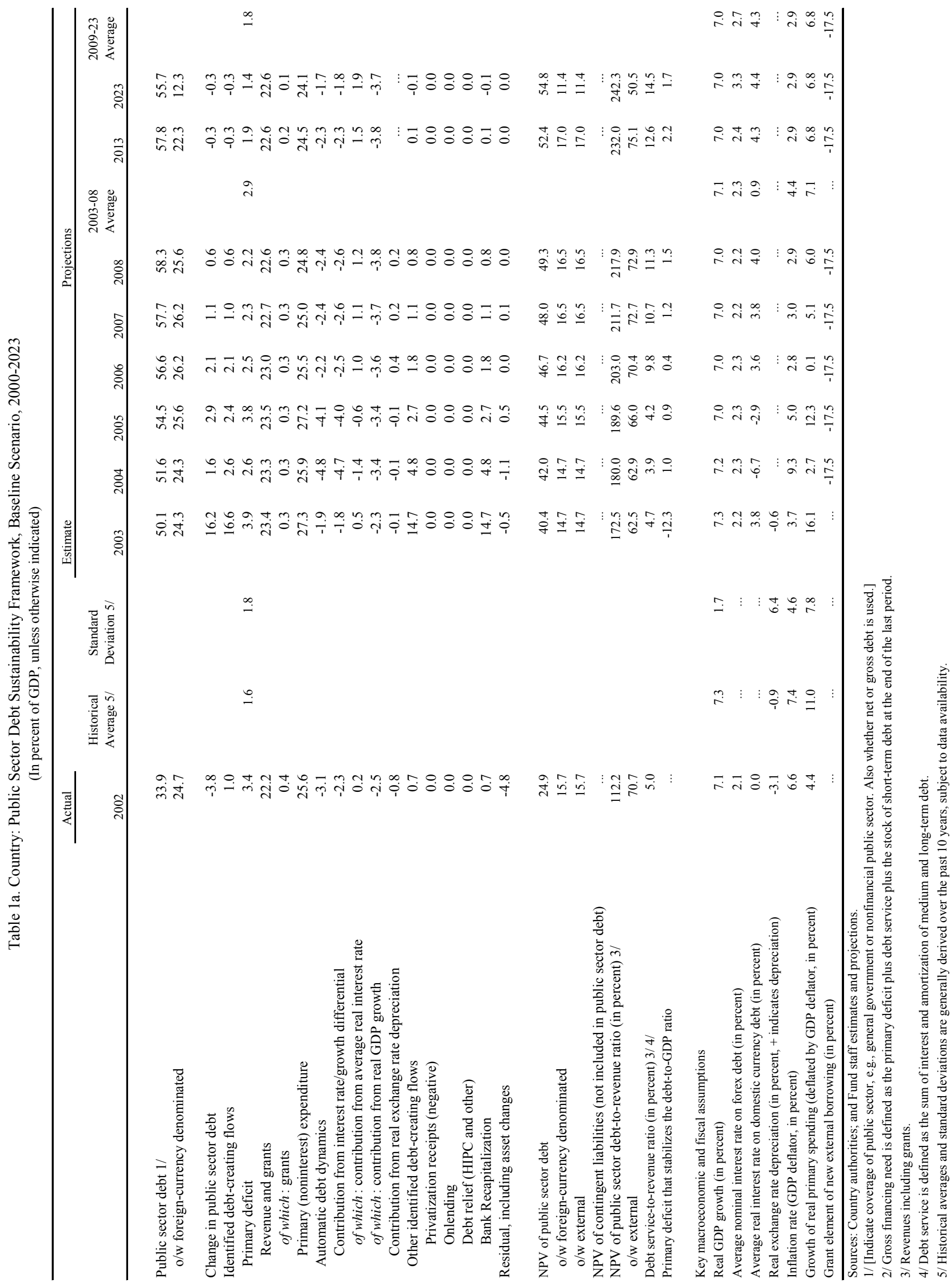


Table 1b. Country: Sensitivity Analyses for Key Indicators of Public Sector Debt , 2003-2023

\begin{tabular}{|c|c|c|c|c|c|c|c|c|}
\hline & Estimate & & & & Projection & & & \\
\hline & 2003 & 2004 & 2005 & 2006 & 2007 & 2008 & 2013 & 2023 \\
\hline NPV of Debt-to-C & & & & & & & & \\
\hline Baseline & 40 & 42 & 44 & 47 & 48 & 49 & 52 & 55 \\
\hline A. Alternative scenarios & & & & & & & & \\
\hline $\begin{array}{l}\text { A1. Real GDP growth and primary balance are at historical averages } \\
\text { A2 Primary balance is unchanged from } 2003\end{array}$ & 41 & 43 & $\begin{array}{l}44 \\
46\end{array}$ & $\begin{array}{l}47 \\
49\end{array}$ & $\begin{array}{l}49 \\
52\end{array}$ & $\begin{array}{l}50 \\
55\end{array}$ & $\begin{array}{l}57 \\
65\end{array}$ & $\begin{array}{l}66 \\
80\end{array}$ \\
\hline A3. Permanently lower GDP growth $1 /$ & 40 & 42 & 45 & 47 & 49 & 51 & 58 & 71 \\
\hline B. Bound tests & & & & & & & & \\
\hline B1. Real GDP growth is at historical average minus one standard deviations in 2004-2005 & 40 & 43 & 47 & 50 & 52 & 54 & 60 & 67 \\
\hline B2. Primary balance is at historical average minus one standard deviations in 2004-2005 & 40 & 43 & 46 & 48 & 50 & 51 & 54 & 56 \\
\hline B3. Combination of 2-3 using one half standard deviation shocks & 40 & 43 & 45 & 48 & 49 & 50 & 53 & 55 \\
\hline B4. One time 30 percent real depreciation in 2004 & 40 & 48 & 50 & 51 & 53 & 54 & 57 & 60 \\
\hline B5. 10 percent of GDP increase in other debt-creating flows in 2004 & 40 & 46 & 49 & 51 & 53 & 54 & 57 & 58 \\
\hline NPV of Debt-to-Rev & & & & & & & & \\
\hline Baseline & 173 & 180 & 190 & 203 & 212 & 218 & 232 & 242 \\
\hline A. Alternative scenarios & & & & & & & & \\
\hline A1. Real GDP growth and primary balance are at historical averages & 175 & 183 & 188 & 203 & 214 & 222 & 251 & 292 \\
\hline A2. Primary balance is unchanged from 2003 & 175 & 187 & 196 & 215 & 230 & 242 & 287 & 356 \\
\hline A3. Permanently lower GDP growth $1 /$ & 171 & 179 & 190 & 206 & 216 & 225 & 255 & 314 \\
\hline B. Bound tests & & & & & & & & \\
\hline B1. Real GDP growth is at historical average minus one standard deviations in 2004-2005 & 173 & 185 & 200 & 218 & 230 & 240 & 267 & 298 \\
\hline B2. Primary balance is at historical average minus one standard deviations in 2004-2005 & 171 & 185 & 197 & 210 & 219 & 225 & 238 & 246 \\
\hline B3. Combination of 2-3 using one half standard deviation shocks & 171 & 184 & 193 & 207 & 216 & 222 & 235 & 245 \\
\hline B4. One time 30 percent real depreciation in 2004 & 171 & 205 & 211 & 224 & 231 & 237 & 252 & 265 \\
\hline B5. 10 percent of GDP increase in other debt-creating flows in 2004 & 172 & 198 & 208 & 222 & 232 & 238 & 252 & 257 \\
\hline Debt Service-to-Rev & & & & & & & & \\
\hline Baseline & 5 & 4 & 4 & 10 & 11 & 11 & 13 & 15 \\
\hline A. Alternative scenarios & & & & & & & & \\
\hline A1. Real GDP growth and primary balance are at historical averages & 5 & 4 & 5 & 9 & 11 & 12 & 15 & 21 \\
\hline A2. Primary balance is unchanged from 2003 & 5 & 4 & 6 & 11 & 13 & 15 & 19 & 28 \\
\hline A3. Permanently lower GDP growth $1 /$ & 5 & 4 & 4 & 10 & 11 & 12 & 15 & 22 \\
\hline B. Bound tests & & & & & & & & \\
\hline B1. Real GDP growth is at historical average minus one standard deviations in 2004-2005 & 5 & 4 & 5 & 12 & 13 & 14 & 16 & 21 \\
\hline B2. Primary balance is at historical average minus one standard deviations in 2004-2005 & 5 & 4 & 6 & 11 & 11 & 12 & 13 & 15 \\
\hline B3. Combination of 2-3 using one half standard deviation shocks & 5 & 4 & 5 & 10 & 11 & 11 & 13 & 15 \\
\hline B4. One time 30 percent real depreciation in 2004 & 5 & 4 & 5 & 11 & 12 & 13 & 14 & 17 \\
\hline B5. 10 percent of GDP increase in other debt-creating flows in 2004 & 5 & 4 & 18 & 15 & 14 & 14 & 14 & 17 \\
\hline
\end{tabular}

Sources: Country authorities; and Fund staff estimates and projections.

1/ Assumes that real GDP growth is at baseline minus one standard deviation divided by the square root of 20 (i.e., the length of the projection period).

2/ Revenues are defined inclusive of grants. 


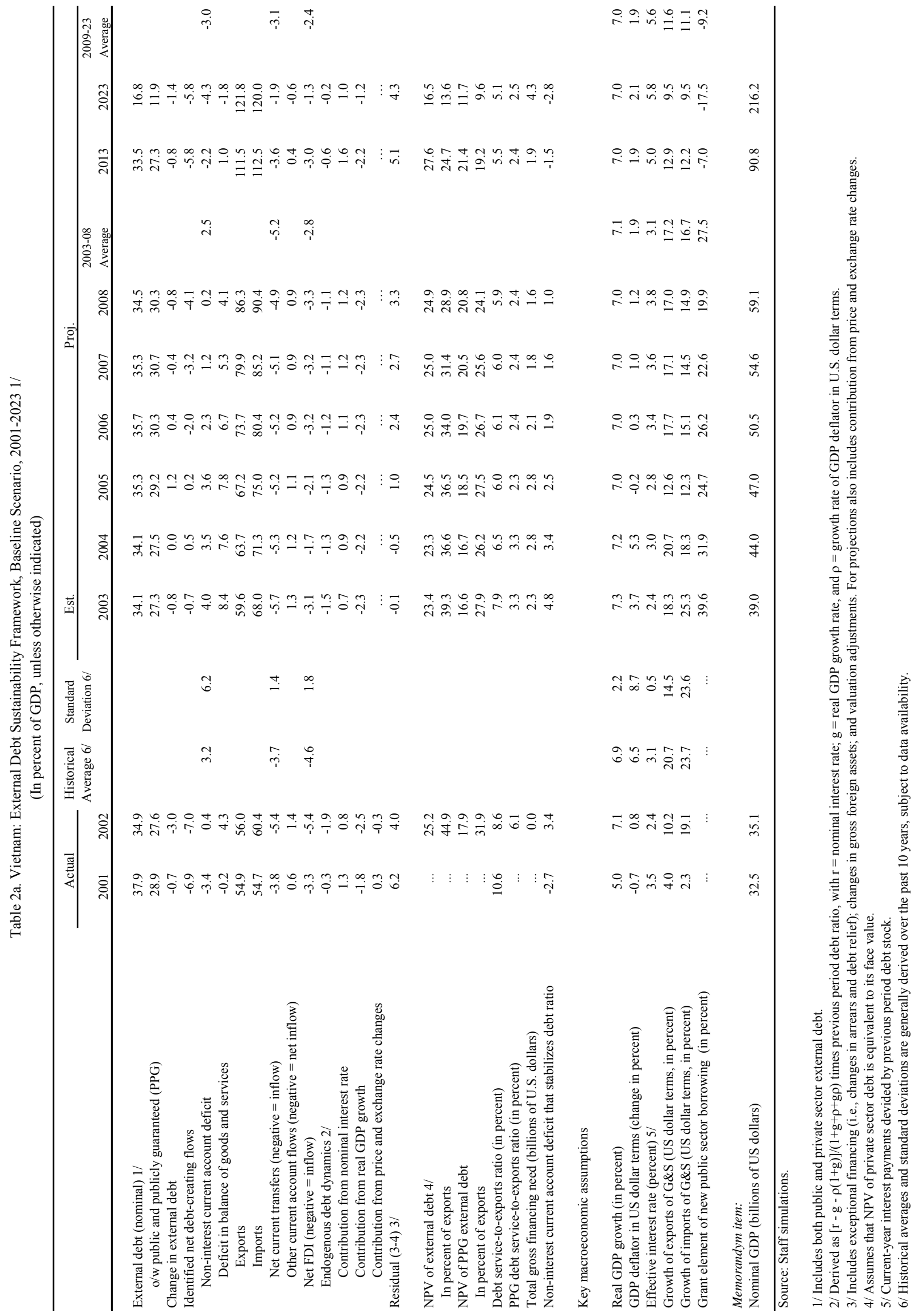


Table 2b. Vietnam: Sensitivity Analyses for Key Indicators of Public and Publicly Guaranteed External Debt, 2003-23 (In percent)

\begin{tabular}{|c|c|c|c|c|c|c|c|c|}
\hline & \multicolumn{4}{|l|}{ Est. } & \multicolumn{4}{|c|}{ Proj. } \\
\hline & 2003 & 2004 & 2005 & 2006 & 2007 & 2008 & 2013 & 2023 \\
\hline \multicolumn{9}{|c|}{ NPV of debt-to-GDP ratio } \\
\hline Baseline & 16.6 & 16.7 & 18.5 & 19.7 & 20.5 & 20.8 & 21.4 & 11.7 \\
\hline \multicolumn{9}{|l|}{ A. Alternative Scenarios } \\
\hline A1. Key variables at their historical averages in $2004-211 /$ & 16.6 & 12.8 & 10.5 & 11.1 & 13.1 & 15.8 & 28.9 & 24.7 \\
\hline A2. New public sector loans on less favorable terms in 2004-21 2/ & 16.6 & 17.7 & 20.9 & 23.3 & 25.2 & 26.4 & 29.6 & 22.3 \\
\hline \multicolumn{9}{|l|}{ B. Bound Tests } \\
\hline B1. Real GDP growth at historical average minus one standard deviation in 2004-05 & 16.6 & 17.1 & 19.3 & 20.6 & 21.4 & 21.7 & 22.4 & 12.2 \\
\hline B2. Export value growth at historical average minus one standard deviation in 2004-05 3/ & 16.6 & 25.7 & 41.0 & 40.7 & 37.8 & 34.5 & 23.4 & 11.7 \\
\hline B3. US dollar GDP deflator at historical average minus one standard deviation in 2004-05 & 16.6 & 17.9 & 20.3 & 21.6 & 22.5 & 22.8 & 23.5 & 12.8 \\
\hline B4. Net non-debt creating flows at historical average minus one standard deviation in 2004-05 4/ & 16.6 & 18.7 & 22.8 & 23.6 & 23.7 & 23.4 & 21.8 & 11.7 \\
\hline B5. Combination of B1-B4 using one-half standard deviation shocks & 16.6 & 25.0 & 33.5 & 33.5 & 32.0 & 29.9 & 23.3 & 12.1 \\
\hline B6. One-time 30 percent nominal depreciation relative to the baseline in 2004 5/ & 16.6 & 23.3 & 25.8 & 27.5 & 28.6 & 29.0 & 29.9 & 16.3 \\
\hline
\end{tabular}

NPV of debt-to-exports ratio

Baseline

$\begin{array}{rrrrrrrr}27.9 & 26.2 & 27.5 & 26.7 & 25.6 & 24.1 & 19.2 & 9.6 \\ & & & & & & & \\ 27.9 & 20.1 & 15.6 & 15.0 & 16.4 & 18.3 & 25.9 & 20.3 \\ 27.9 & 27.8 & 31.1 & 31.6 & 31.6 & 30.6 & 26.6 & 18.3 \\ & & & & & & & \\ & & & & & & & \\ 27.9 & 26.2 & 27.5 & 26.7 & 25.6 & 24.1 & 19.2 & 9.6 \\ 27.9 & 45.9 & 73.6 & 66.6 & 57.2 & 48.2 & 25.3 & 11.6 \\ 27.9 & 26.2 & 27.5 & 26.7 & 25.6 & 24.1 & 19.2 & 9.6 \\ 27.9 & 29.3 & 33.9 & 32.1 & 29.7 & 27.1 & 19.5 & 9.6 \\ 27.9 & 39.9 & 51.0 & 46.6 & 41.0 & 35.6 & 21.4 & 10.2 \\ 27.9 & 26.2 & 27.5 & 26.7 & 25.6 & 24.1 & 19.2 & 9.6\end{array}$

A. Alternative Scenarios

A1. Key variables at their historical averages in 2004-21 1/

A2. New public sector loans on less favorable terms in 2004-21 2/

B. Bound Tests

B1. Real GDP growth at historical average minus one standard deviation in 2004-05

B2. Export value growth at historical average minus one standard deviation in 2004-05 3/

B3. US dollar GDP deflator at historical average minus one standard deviation in 2004-05

B4. Net non-debt creating flows at historical average minus one standard deviation in 2004-05 4/

B5. Combination of B1-B4 using one-half standard deviation shocks

B6. One-time 30 percent nominal depreciation relative to the baseline in $20045 /$

Debt service ratio

Baseline

3.4
3.4

.4

3.3

1

A1. Key variables at their historical averages in 2004-21 1/

B. Bound Tests

B1. Real GDP growth at historical average minus one standard deviation in 2004-05

B2. Export value growth at historical average minus one standard deviation in 2004-05 3/

B3. US dollar GDP deflator at historical average minus one standard deviation in 2004-05

B4. Net non-debt creating flows at historical average minus one standard deviation in 2004-05 4

B5. Combination of B1-B4 using one-half standard deviation shocks

B6. One-time 30 percent nominal depreciation relative to the baseline in 2004 5/

Memorandum item:

Grant element assumed on residual financing (i.e., financing required above baseline) 6/

Source: Staff projections and simulations.

1/ Variables include real GDP growth, growth of GDP deflator (in U.S. dollar terms), non-interest current account in percent of GDP, and non-debt creating flows.

2/ Assumes that the interest rate on new borrowing is by 2 percentage points higher than in the baseline., while grace and maturity periods are the same as in the baseline.

3/ Exports values are assumed to remain permanently at the lower level, but the current account as a share of GDP is assumed to return to its baseline level after the shock (implicitly assuming an offsetting adjustment in import levels).

4/ Includes official and private transfers and FDI.

5/ Depreciation is defined as percentage decline in dollar/local currency rate, such that it never exceeds 100 percent.

6/ Applies to all stress scenarios except for A2 (less favorable financing) in which the terms on all new financing are as specified in footnote 2. 


\section{Vietnam: Millenium Development Goals}

(In percent, unless otherwise specified)

\begin{tabular}{|c|c|c|c|c|}
\hline & 1990 & 1995 & 2001 & 2002 \\
\hline 1 Eradicate extreme poverty and hunger & \multicolumn{4}{|c|}{2015 target $=$ halve $1990 \$ 1$ a day poverty and malnutrition rates } \\
\hline Population below $\$ 1$ a day & .. &.. & .. & .. \\
\hline Poverty gap at $\$ 1$ a day & .. &.. & .. & .. \\
\hline Share of income or consumption held by poorest 20 percent &.. &.. &.. & .. \\
\hline Prevalence of child malnutrition (percent of children under 5) & 45.0 & 44.9 & 33.8 & .. \\
\hline Share of population below minimum level of dietary energy consumpti & 27.0 & 21.0 & 19.0 & .. \\
\hline 2 Achieve universal primary education & \multicolumn{4}{|c|}{2015 target $=$ net enrollment to 100} \\
\hline Net primary enrollment ratio (percent of relevant age group) & .. & 87.8 & 94.0 & .. \\
\hline Percentage of cohort reaching grade 5 &.. &.. & 89.0 & .. \\
\hline Youth literacy rate (ages 15-24) & 94.1 & 94.4 &.. & .. \\
\hline 3 Promote gender equality & \multicolumn{4}{|c|}{2005 target $=$ education ratio to 100} \\
\hline Ratio of girls to boys in primary and secondary education &.. &.. & 92.7 & .. \\
\hline Ratio of young literate females to males (percent ages 15-24) & 99.1 & 99.9 &.. & .. \\
\hline Share of women employed in the nonagricultural sector & 52.9 &.. &.. & .. \\
\hline Proportion of seats held by women in national parliament &.. & 18.0 &.. & .. \\
\hline 4 Reduce child mortality & \multicolumn{4}{|c|}{2015 target $=$ reduce 1990 under 5 mortality by two-thirds } \\
\hline Under 5 mortality rate (per 1,000$)$ & 53.0 & 44.0 & 30.0 & 26.0 \\
\hline Infant mortality rate (per 1,000 live births) & 38.0 & 32.0 & 23.0 & 20.0 \\
\hline Immunization, measles (percent of children under 12 months) & 85.0 & 96.0 & 97.0 & 96.0 \\
\hline 5 Improve maternal health & \multicolumn{4}{|c|}{2015 target $=$ reduce 1990 maternal mortality by three-fourths } \\
\hline Maternal mortality ratio (modeled estimate, per 100,000 live births) &.. &.. & 130.0 & .. \\
\hline Births attended by skilled health staff (percent of total) & .. & 77.1 & 69.6 & 85.0 \\
\hline 6 Combat HIVIAIDS, malaria and other diseases & \multicolumn{4}{|c|}{2015 target $=$ halt, and begin to reverse, AIDS, etc. } \\
\hline Prevalence of HIV, female (ages 15-24) & .. & & 0.2 & .. \\
\hline Contraceptive prevalence rate (of women ages 15-49) & .. & 75.3 &.. & 78.5 \\
\hline Number of children orphaned by HIVIAIDS & .. &.. & $22,000.00$ & .. \\
\hline Incidence of tuberculosis (per 100,000 people) & .. &.. & 179.0 & 192.5 \\
\hline Tuberculosis cases detected under DOTS & .. & 30.0 & 85.0 & 81.9 \\
\hline 7 Ensure environmental sustainability & \multicolumn{4}{|c|}{2015 target $=$ various $1 /$} \\
\hline Forest area (percent of total land area) & 28.6 &.. & 30.2 & .. \\
\hline Nationally protected areas (percent of total land area) &.. & 3.0 & 3.1 & 3.5 \\
\hline GDP per unit of energy use (PPP \$ per kg oil equivalent) & 2.6 & 3.5 & 4.4 & .. \\
\hline CO2 emissions (metric tons per capita) & 2.6 & 0.4 & 0.7 & .. \\
\hline Access to an improved water source (percent of population) & 55.0 &.. & 77.0 & .. \\
\hline Access to improved sanitation (percent of population) & 29.0 & .. & 47.0 & .. \\
\hline Access to secure tenure (percent of population) &.. &.. &.. & .. \\
\hline 8 Develop a Global Partnership for Development & \multicolumn{4}{|c|}{2015 target $=$ various $2 /$} \\
\hline Youth unemployment rate (percent of total labor force ages 15-24) &.. &.. &.. &.. \\
\hline Fixed line and mobile telephones (per 1,000 people) & 1.5 & 10.8 & 53.0 & 71.8 \\
\hline Personal computers (per 1,000 people) & 0.1 & 1.4 & 8.6 & 9.8 \\
\hline \multicolumn{5}{|l|}{ General indicators } \\
\hline Population (in millions) & 66.2 & 73.0 & 79.5 & 80.4 \\
\hline Gross national income (U.S. \$ billions) & 8.5 & 18.5 & 32.3 & 34.8 \\
\hline GNI per capita (U.S. \$) & 130.0 & 250.0 & 410.0 & 430.0 \\
\hline Adult literacy rate (percent of people ages 15 and over) & 90.4 & 91.5 & 90.3 & .. \\
\hline Total fertility rate (births per woman) & 3.6 & 2.7 & 1.9 & 1.9 \\
\hline Life expectancy at birth (years) & 64.8 & 67.1 & 69.1 & 69.7 \\
\hline Aid (percent of GNI) & 3.1 & 4.1 & 4.5 & 3.6 \\
\hline
\end{tabular}

\section{Source: World Development Indicators database, April 2004}

$1 /$ Integrate the principles of sustainable development into country policies and programs and reverse the loss of environmental resources. Halve, by 2015 , the proportion of people without sustainable access to safe drinking water. By 2020 , to have achieved a significant improvement in the lives of at least 100 million slum dwellers.

2/ Develop further an open, rule-based, predictable, non-discriminatory trading and financial system. Address the Special Needs of the Least Developed Countries. Address the Special Needs of landlocked countries and small island developing states. Deal comprehensively with the debt problems of developing countries through national and international measures in order to make debt sustainable in the long term. In cooperation with developing countries, develop and implement strategies for decent and productive work for youth. In cooperation with pharmaceutical companies, provide access to affordable, essential drugs in developing countries. In cooperation with the private sector, make available the benefits of new technologies, especially information and communications. 


\section{INTERNATIONAL MONETARY FUND}

EXTERNAL

Public Information Notice

RELATIONS

DEPARTMENT

Public Information Notice (PIN) No. 05/001

FOR IMMEDIATE RELEASE

January 5, 2005

International Monetary Fund

$70019^{\text {th }}$ Street, NW

Washington, D. C. 20431 USA

\section{IMF Executive Board Concludes 2004 Article IV Consultation with Vietnam}

On November 22, 2004, the Executive Board of the International Monetary Fund (IMF) concluded the Article IV consultation with Vietnam. ${ }^{1}$

The three-year PRGF arrangement expired in April 2004. During the arrangement, Vietnam maintained strong economic growth and low inflation and achieved further poverty reduction, supported by favorable macroeconomic conditions and increasing integration with the world economy facilitated by trade liberalization.

Since the last Article IV Consultation, Vietnam's economy has performed well. Real GDP grew by $7 \frac{1}{4}$ percent in 2003 , led by strong investment and export growth. Growth slowed in the first quarter of 2004 mainly due to the impact of the avian flu outbreak and droughts on agricultural production, but began to rebound in the following months; agricultural production has recovered and industrial production has picked up. Inflation rose from 3 percent at end-2003 to 10 percent in September 2004 (both year-on-year), reflecting the jump in food prices, which comprise about half of the CPI basket. Since July, however, annualized monthly inflation has fallen rapidly.

Vietnam's overall balance of payments has strengthened notwithstanding the widened current account deficit. Although exports grew rapidly, surging imports driven by strong investment

\footnotetext{
${ }^{1}$ Under Article IV of the IMF's Articles of Agreement, the IMF holds bilateral discussions with members, usually every year. A staff team visits the country, collects economic and financial information, and discusses with officials the country's economic developments and policies. On return to headquarters, the staff prepares a report, which forms the basis for discussion by the Executive Board. At the conclusion of the discussion, the Managing Director, as Chairman of the Board, summarizes the views of Executive Directors, and this summary is transmitted to the country's authorities.
}

Washington, D.C. 20431 • Telephone 202-623-7100 • Fax 202-623-6772 • www.imf.org 
increased the current account deficit to $43 / 4$ percent of GDP in 2003 . With the deficit more than fully financed through a combination of higher long-term capital inflows and a substantial rundown of domestic banks' foreign assets, Vietnam's international reserves significantly increased, reaching US $\$ 5.6$ billion at end-2003 (about nine weeks of imports). This increase, however, slowed considerably in the first seven months of 2004, despite continued strong export growth and a slowdown in import growth.

Credit growth has accelerated, and monetary aggregates continue to grow rapidly. Credit growth accelerated to 28 percent at end-2003 and further to 36 percent in July 2004 . The sharp increase in credit growth in 2004 was led by the state-owned sector. Broad money growth rose to 25 percent in 2003 and stayed at about the same level in the first seven months of 2004, reflecting the ongoing monetization. Short-term dong deposit and lending rates rose only slightly in recent months.

In response to rising inflation and higher credit growth, the authorities have taken a series of measures. They substantially increased reserve requirements and adjusted several administered prices, including a lowering of tariffs on petroleum and steel products. More recently, the Prime Minister issued a directive calling for a cut in government expenditure and lending by state-owned banks, a strengthening of enterprises' efforts to reduce production and distribution cots, and a tightening of price control enforcement.

For 2004 as a whole, economic growth and the external current account are likely to be broadly unchanged from 2003, with inflation falling toward the end of the year and the budget deficit narrowing. Real GDP growth in 2004 is likely to be at 7-71/2 percent, aided by a recovery in agriculture and a pick up in industrial production in the second half of the year. Inflation is expected to fall to $91 / 2$ percent (year on year) by the end of the year. The current account deficit is projected to be at $4 \frac{1}{2}$ percent of GDP, financed by a combination of official development aid and foreign direct investment inflows. Reduced short-term capital inflows, however, would allow for only a modest accumulation of international reserves. Initiatives to tighten projects' eligibility requirements for domestically-financed on-lending and reduced expenditure are expected to lead to a significant fiscal tightening compared to 2003.

Vietnam's economic growth is projected to remain strong in 2005 and beyond, with real GDP growing at about 7 percent per year. Achievement of this outlook, however, depends on progress in private sector development and structural reforms, especially in the areas of stateowned banks and enterprises to contain the build-up of public sector debt, and WTO accession-which is key to sustained strong export growth. While there has been continued progress in the areas of private sector development and trade reform, progress in reforming the state-owned sector continues to be slow. 


\section{Executive Board Assessment}

Executive Directors commended the authorities for their strong record of success in achieving high growth and poverty reduction over the past years, their prudent macroeconomic management, and Vietnam's increasing integration into the global economy. Directors encouraged the authorities to build on these achievements in order to sustain the momentum of strong growth and poverty reduction into the medium term. This will hinge on structural reforms in key areas, including restructuring of state-owned banks and enterprises, improving the private sector investment climate, securing WTO accession, and enhancing governance and the transparency of policy making.

Directors noted that the near-term economic outlook appears favorable, provided that the authorities can contain second-round inflationary effects from the recent supply-side price shocks. They welcomed the authorities' aim to contain these effects, as indicated by recent monetary policy actions supplemented by a number of administrative and fiscal measures. Directors encouraged the State Bank of Vietnam (SBV) to tighten monetary conditions further using more conventional means, especially by raising interest rates, if these measures prove insufficient. They advised that the central bank eliminate conflicting policy objectives and move toward increased reliance on indirect policy instruments.

Directors cautioned that the currently rapid rate of credit growth should be reduced significantly in light of uncertain loan quality and the banks' weak balance sheets. While noting that the significant increase in the reserve requirement ratios has reduced liquidity in the banking system, Directors urged the SBV to take further measures if the pace of credit growth does not fall significantly. They cautioned that maintaining rapid credit growth to meet the government's short-term growth target could lead to mounting quasi-fiscal liabilities, which could threaten fiscal sustainability and long-term growth.

Directors encouraged the authorities to move cautiously toward greater exchange rate flexibility, which would facilitate adjustments to external shocks and rapid structural changes. Accordingly, Directors urged the authorities to limit foreign exchange intervention to addressing disorderly conditions. This will help strengthen Vietnam's modest reserve position. They noted that increased exchange rate flexibility would also encourage market participants to manage exchange rate risks, thereby avoiding excessive foreign exchange exposure in the economy. Directors also encouraged the authorities to eliminate remaining exchange restrictions and to accept Article VIII obligations.

Directors commended the authorities for their prudent fiscal management in 2004. They emphasized the importance of setting budget targets for 2005 and beyond consistent with medium-term public debt sustainability, taking into account the existing stock of quasi-fiscal liabilities and the costs associated with the financial sector reforms. In this regard, Directors highlighted possible budget pressures from the fiscal costs of state-owned bank and enterprise restructuring, stagnating oil revenues, and revenue pressures from further trade liberalization. Directors encouraged the authorities to begin identifying possible tax measures in addition to ongoing tax administration efforts to achieve their goal of holding revenue steady as a share of output over the medium term. They called for discontinuation of price subsidies as soon as possible. 
Directors emphasized that Vietnam's state-owned commercial banks are an important source of vulnerability in the economy, given their dominance and uncertain asset quality. They urged faster progress in reforming these banks. Directors welcomed the authorities' decision to equitize one of the four large banks, noting that this initiative could provide impetus to state bank reform provided that the equitization ultimately shifts the bank's operations to a more commercial basis. In this regard, Directors recommended that consideration be given to selling a large share of the bank to a foreign strategic partner, which, country experiences suggest, can be an effective way to improve the performance of state-owned banks. In addition to equitization, they underscored that a more active ownership role by the Ministry of Finance and measures to strengthen the SBV's supervision are important elements of state bank reform. Directors considered that further developing money and capital markets and the stock exchange should be an integral part of financial sector reform. They also called for independent audits at the central bank and swift progress in establishing effective means of combating money laundering and terrorism financing.

Directors emphasized the importance of further developing the private sector and improving the efficiency of state-owned enterprises for Vietnam's successful transition to a more marketoriented economy. In this regard, Directors welcomed initiatives to reduce the number of strategic sectors in which state-owned enterprises remain under full state ownership and to expand the equitization program to include large state-owned enterprises. They emphasized the importance of focusing the design of the equitization plans on strengthening commercial incentives for managers, increasing accountability, and improving performance. Directors noted that the elimination of regulations discriminating against the private sector and measures supporting small and medium enterprises have helped the private sector expand rapidly, and urged further improvements through full implementation of the Land Law to facilitate private investment, and unification of the investment and enterprise laws to promote a level playing field.

Directors supported Vietnam's objective of achieving early WTO membership, emphasizing its importance for Vietnam in maintaining market access, sustaining foreign direct investment inflows, and furthering integration into the international economy. They noted, however, that early entry requires significant actions, including putting in place necessary legislation.

Directors emphasized the need for Vietnam to improve transparency as well as reliability and timeliness of data. They welcomed the passage of the new Statistics Law, which would improve data collection by strengthening inter-agency coordination, but noted that Vietnam's macroeconomic statistics had significant weaknesses, and supported the provision of Fund technical assistance to improve the statistical base.

Directors welcomed the opportunity to review the Fund's past engagement with Vietnam, focusing on the three-year PRGF arrangement that expired in April 2004. They observed that Vietnam achieved further poverty reduction through maintaining strong economic growth and low inflation throughout the PRGF period. Nevertheless, valuable lessons of the ex post assessment are that sufficient time should be allowed for the institutional changes that underpin structural reforms, and that coordination between the Fund and the World Bank and other bilateral donors needs to be improved. While commending the impressive progress in trade liberalization, Directors noted that the pace of reforming state-owned commercial banks 


$$
-5-
$$

and enterprises has been slow and highlighted the need for fundamental institutional changes to address weaknesses in these areas. Fund technical assistance will be important in this regard.

Public Information Notices (PINs) form part of the IMF's efforts to promote transparency of the IMF's views and analysis of economic developments and policies. With the consent of the country (or countries) concerned, PINs are issued after Executive Board discussions of Article IV consultations with member countries, of its surveillance of developments at the regional level, of post-program monitoring, and of ex post assessments of member countries with longer-term program engagements. PINs are also issued after Executive Board discussions of general policy matters, unless otherwise decided by the Executive Board in a particular case. 
Vietnam: Selected Economic Indicators, 2000-04

\begin{tabular}{|c|c|c|c|c|c|}
\hline & 2000 & 2001 & 2002 & $\frac{2003}{\text { Est. }}$ & $\frac{2004}{\text { Proj. }}$ \\
\hline Real GDP (annual percentage change) & 6.8 & 6.9 & 7.1 & 7.3 & $7-71 / 2$ \\
\hline Industrial output & 18.4 & 13.7 & 18.8 & 16.9 & $\ldots$ \\
\hline \multicolumn{6}{|l|}{ Inflation (annual percentage change) } \\
\hline Period average & -1.6 & -0.4 & 4.0 & 3.2 & $7-8$ \\
\hline End of period & -0.5 & 0.7 & 4.0 & 2.9 & $91 / 2$ \\
\hline Saving-investment balance & 2.1 & 2.1 & -1.2 & -4.7 & -4.4 \\
\hline Gross national saving & 31.7 & 33.2 & 32.0 & 30.4 & 31.1 \\
\hline Gross investment & 29.6 & 31.2 & 33.2 & 35.1 & 35.5 \\
\hline ICOR & 4.1 & 4.2 & 4.4 & 4.5 & 4.6 \\
\hline \multicolumn{6}{|l|}{ General government budget } \\
\hline Total revenue and grants & 20.5 & 21.6 & 22.2 & 23.4 & 23.3 \\
\hline of which: oil revenue & 6.5 & 7.4 & 6.6 & 6.5 & 6.7 \\
\hline Total Expenditure and net lending & 25.5 & 26.6 & 26.8 & 28.4 & 26.8 \\
\hline Current expenditure & 15.9 & 16.0 & 15.8 & 17.0 & 16.3 \\
\hline Capital expenditure & 7.4 & 8.4 & 8.2 & 8.4 & 7.8 \\
\hline Net lending 2/ & 2.2 & 2.2 & 2.7 & 2.9 & 2.7 \\
\hline Fiscal balance & -5.0 & -5.0 & -4.5 & -5.0 & -3.5 \\
\hline (Excluding net lending) & -2.7 & -2.8 & -1.9 & -2.0 & -0.8 \\
\hline \multicolumn{6}{|l|}{ Money and credit (annual percentage change, end of period) } \\
\hline Broad money & 39.0 & 25.5 & 17.6 & 24.9 & $\ldots$ \\
\hline Credit to the economy & 38.1 & 21.4 & 22.2 & 28.4 & $\ldots$ \\
\hline \multicolumn{6}{|l|}{ Interest rates (in percent, end of period) } \\
\hline Three-month deposits (households) & 4.3 & 5.9 & 7.0 & 6.3 & $\ldots$ \\
\hline Short-term lending (less than one year) & 9.8 & 8.8 & 9.9 & 10.0 & $\ldots$ \\
\hline \multicolumn{6}{|l|}{ Current account balance (including official transfers) } \\
\hline (in millions of U.S. dollars) & 642 & 670 & -421 & $-1,844$ & $-1,930$ \\
\hline (in percent of GDP) & 2.1 & 2.1 & -1.2 & -4.7 & -4.4 \\
\hline Exports f.o.b (annual percentage change, U.S. dollar terms) & 25.2 & 4.0 & 11.2 & 19.6 & 22.9 \\
\hline Imports f.o.b. (annual percentage change, U.S. dollar terms) & 34.5 & 2.3 & 22.1 & 27.9 & 20.1 \\
\hline \multicolumn{6}{|l|}{ Foreign exchange reserves (in millions of U.S. dollars, end of period) } \\
\hline Gross official reserves, including gold & 3,030 & 3,387 & 3,692 & 5,620 & 6,004 \\
\hline (in weeks of next year's imports of goods and nonfactor services) & 8.9 & 8.3 & 7.3 & 9.3 & 8.9 \\
\hline Net international reserves, including gold & 2,191 & 2,555 & 2,956 & 4,683 & $\ldots$ \\
\hline External debt (in percent of GDP) $3 /$ & 38.6 & 37.9 & 34.9 & 34.1 & 34.0 \\
\hline Debt service due (in percent of exports of goods and nonfactor services) & 10.5 & 10.6 & 8.6 & 7.9 & 6.5 \\
\hline \multicolumn{6}{|l|}{ Exchange rate (dong per U.S. dollar) } \\
\hline Period average & 14,170 & 14,806 & 15,272 & 15,514 & $\ldots$ \\
\hline End of period & 14,514 & 15,084 & 15,404 & 15,646 & $\ldots$ \\
\hline \multicolumn{6}{|l|}{ Real effective exchange rate (annual percentage change) } \\
\hline Period average & -2.8 & 0.9 & -0.6 & -5.0 & $\ldots$ \\
\hline End of period & 2.2 & 1.3 & -4.1 & -6.2 & $\ldots$ \\
\hline \multicolumn{6}{|l|}{ Memorandum items: } \\
\hline GDP (in trillions of dong at current market prices) & 441.6 & 481.3 & 535.8 & 605.6 & 716.8 \\
\hline Per capita GDP (in U.S. dollars) & 401 & 413 & 440 & 483 & 537 \\
\hline
\end{tabular}

Sources: Data provided by the authorities; and Fund staff estimates and projections.

$1 /$ Data as of August 2004, unless otherwise indicated.

2/ Includes DAF operations. The authorities record ODA received for onlending; repayments are included under amortization.

$3 /$ Includes the loan component of foreign direct investment and other private sector borrowing and short-term debt. 


\section{Statement by Made Sukada, Alternate Executive Director for Vietnam and Worawut Wesaratchakit, Advisor to Executive Director \\ November 22, 2004}

\section{Introduction}

1. On behalf of the Vietnamese authorities, we would like to express their appreciation to the staff, management and the Executive Board as well as to other development partners and the donor community for their advice and continued support. The authorities would also like to thank the staff for a balanced Staff Report for the 2004 Article IV Consultation as well as the useful policy advice. The authorities also find that the Ex Post Assessment of LongerTerm Program Engagement paper is well-written and balanced, highlighting Vietnam's various achievements during the Fund supported program.

2. The Vietnamese authorities have succeeded in laying down a conducive platform for the economic transformation from a centrally-planned to a market-based economy. A combination of favorable macroeconomic conditions and increasing integration with the world economy, facilitated by speedy trade reforms, have contributed to strong economic growth, low inflation and impressive poverty reduction in recent years. With these achievements, the Vietnamese authorities are strongly committed to acquiring WTO accession in 2005. The authorities also recognize that there remain some challenges ahead. In this respect, they are committed to continue the implementation of structural reforms to ensure the country's sustainable development.

\section{Recent Economic Developments and Outlook}

3. Real GDP growth in 2003 continued to be strong, led by robust investment, exports, and private consumption. In the first quarter of 2004, however, agricultural production fell, mainly due to the avian flu outbreak and drought. At the same time, manufacturing and construction activities slowed, induced by higher world commodity prices, notably for steel. As a result, the consumer price index rose from a moderate rate in 2003, driven largely by these supply shocks. Following the adoption of a number of stimulus measures by the authorities, economic activity began to pick up, and the economic slowdown earlier in the year proved to be only temporary.

4. For 2004 as a whole, GDP growth is expected to remain favorable. The current account deficit that widened in 2003 due mainly to imports of machinery and intermediate products, was more than offset by strong capital inflows in the forms of both ODA and FDI. This has resulted in a generally satisfactory balance of payments in 2003, and the State Bank of Vietnam (SBV) has managed to increase its international reserves. The current account deficit ratio to GDP has begun to improve in 2004 and the gross official reserves is projected to reach over $\$ 6$ billion (equivalent to around 10 weeks of imports).

5. In line with the staff's projections, the Vietnamese medium-term outlook appears favorable with real GDP growth expected to be around 7 percent per year, supported by 
export expansion-notably from the manufacturing sector, presuming a successful WTO accession by end-2005. The external position is expected to remain manageable as the current account deficit is expected to decline gradually, while capital inflows are expected to increase, led by strong FDI on account of the WTO accession.

\section{Fiscal Policy}

6. Recognizing the importance of and the key role played by fiscal policy in achieving macroeconomic stability, the Vietnam authorities have continued to pursue a prudent fiscal policy to ensure a favorable macroeconomic and financial environment, as a foundation for sustainable growth. The fiscal stance was loosened slightly in 2003, to focus on the long-term critical objectives including higher spending on education, increased capital spending on important transportation and irrigation projects, and net lending. However, the fiscal deficit was contained at around 4.4 percent of GDP.

7. In 2004, the issuance of Government bonds for the investment in the important transportation and irrigation projects has continued, but the above-mentioned deficit has not increased. At the same time, budget revenue has been on an upward trend, at 22-23 percent of GDP, thanks to the improved revenues from crude oil and land use, and improvements in tax administrative measures, e.g. a self-assessment process for potential and new tax payers to be completed by January 2005 .

8. On the expenditure side, the Government issued a State Development Investment Credit Decree on April 1, 2004, to scale down the list of enterprises that may be eligible for on-lending, and to impose specific limits on the total state support not to exceed 85 percent of total project costs. This, along with the authorities' long-standing efforts to bring interest rates on these projects more in line with market rates, will keep domestically financed onlending in check, such that they would begin to decline steadily relative to GDP over the medium term.

\section{Monetary and Exchange Rate Policy}

9. The consumer price index, which was moderate in 2003, rose in the first half of 2004 as a result of temporary supply shocks. Since July, the food consumer price index has fallen rapidly, causing the annualized monthly core inflation for September to fall to $4 \frac{1}{2}$ percent. Given that the unexpected increase in the inflation rate did not stem from monetary policy, the authorities perceived that using this policy to contain inflation will be less effective. Instead, the authorities prefer to use more indirect instruments. To curb inflation, the authorities temporarily reduced tariffs on key commodities, in particular, petroleum and steel products. They, however, acknowledge and agree with staff that additional measures may be needed to contain inflation, as well as to safeguard against any further rise in NPLs.

10. The SBV understands the staff's concern on the impact of the credit growth on NPLs. However, it should be noted that the growth in bank credit reflects bank financing for medium-term investment projects that would otherwise not be undertaken. In this context, due to the segmentation of the financial sector, the reserve requirement is considered to be a 
more effective tool than interest rate policy. Besides being unobtrusive in its implementation, an increase in the reserve requirement should have relatively milder impacts on commercial banks' balance sheets.

11. On exchange rate policy, the authorities are committed to provide continuous support and to facilitate international trade and investment and address any effect of possible shocks, including the second-round effects of inflation. Over the longer term horizon, steps towards a more flexible exchange rate regime will be taken cautiously and gradually, if and only when the markets are perceived to be able to manage the additional risks and volatilty more on their own in an effective and sustainable manner. In the meantime, certain administrative measures will remain essential for the protection of the domestic economic and financial systems.

12. In the medium-term, as the Vietnamese economy becomes more integrated into the global and regional economies, the authorities are aware that present constraints (in particular financial sector segmentation and exchange controls) inherent in the system will need to be addressed. Nevertheless, the authorities would like to reiterate their intention that, in order to be able to accept Article VIII obligations, the authorities would like to request the Fund to continue providing technical assistance to assist the completion of the revision of current relating regulations.

\section{Structural Reforms}

13. The authorities are aware that sustained economic growth and lasting poverty reduction would hinge on the pace of structural reform, aimed at improving efficiency of the state-owned sector, ensuring public debt sustainability, and encouraging private investment. Measures implemented so far are in line with the Communist Party Plenum which was held in January 2004 which called for an acceleration in several structural reforms, including the initiative of equitizing state-owned commercial banks (SOCBs), increasing the pace of equitizing major state-owned enterprises (SOEs), securing WTO accession, and enhancing governance and transparency of policy making.

14. On the financial sector, to enhance the operations of the financial sector, the authorities issued credit manuals for SOCBs early this year, so that they will function on a more commercial basis. Furthermore, the authorities have decided to equitize the Vietcom Bank (VCB). Here, foreigners are welcome to participate through the domestic capital market within the supervisory framework of the authorities. For further steps on this front, the authorities will adopt a gradual approach to minimize social costs of reform and to pick the best timing to approach the investors.

15. The equitization plan, originally scheduled for submission to the Prime Minister by end-June 2004, has been delayed. This was due to some constraints in the prevailing legal framework, such as the lack of specific regulation suitable to the characteristics of the SOCBs in the current Decree on SOE equitization, as well as some technical difficulties. The SBV and the SOCBs concerned have actively cooperated with the relevant agencies to complete this plan for prompt submission to the Prime Minister. An important feature of the 
plan is the sale of shares, possibly through public auction, with the Government retaining a reasonable shareholding. In a number of cases e.g. Mekong Housing Bank, more direct involvement by foreign strategic partners are also under consideration.

16. With regard to transparency, the authorities have continued their effort in improving the reliability and timeliness of data, in a number of areas. Towards this end, a new Statistics Law was passed in January 2004 to enhance data collection by strengthening inter-agency coordination. In addition, with technical assistance given by the Fund since September 2004, the country's national income account statistics can be further improved.

17. On NPLs, the SBV has also initiated a compilation of financial indicators on banks' large borrowers through a survey in April 2004, as a step toward obtaining a more accurate assessment of the SOCBs' balance sheet problems. However, due to the lack of capacity, as well as both statistical and technical difficulties, the report is yet to be completed. Once these constraints have been addressed, the survey could be replicated on a regular basis to provide an effective monitoring framework on banks' performances.

\section{Ex Post Assessment}

18. On the Ex Post Assessment of Longer-Term Program Engagement, the authorities welcome the report as both candid and balanced. As noted by staff, despite the limitations and issues in developing and implementing the ESAF and PRGF programs, the authorities remain committed to continue the reform process.

19. On certain issues, however, a more flexible implementation of the Fund's conditionality could have better assisted Vietnam in sustaining its reform efforts within the program context. The speed of adjustment in quota and tariff rates under the ESAF program, should be kept in line with WTO principles and consistent with other multilateral and bilateral trade agreements. The scope and schedule of SOE reforms should also give due consideration to domestic economic and political feasibility, as well as readiness.

20. Overall, the authorities greatly appreciated the Fund's advice and technical assistance, which are useful in assisting Vietnam to achieve significant macroeconomic stabilization, creating conditions for high and sustainable economic growth, and accelerating structural reforms well beyond the PRGF program. This being the main features that attracted Vietnam to the Fund's program in the first place. The Fund's policy advice and technical assistance will continue to be highly valued by the authorities either within or outside the program context.

\section{Conclusion}

21. With continuous support from the international community as well as the authorities' efforts to implement structural reforms and pursue sound macroeconomic policies, Vietnam has made considerable progress. Nevertheless, the authorities are also aware that some challenges remain in a number of areas such as the improvement of investment quality (ICOR), WTO accession, and the resolution of SOCBs' NPLs. As such, the authorities are 
firmly committed to pursue a sound macroeconomic policy framework and to continue reforms, particularly on SOCBs and SOEs as deemed essential for Vietnam's strong growth path over the medium term. The Vietnamese authorities look forward to the continuation of the close and effective cooperation, as in the past, with the Fund through the communication and consultation on macroeconomic policies. 